\title{
Heat Transfer Studies in Salt and Granite
}

\author{
R. A. Just
}

\section{$?$}

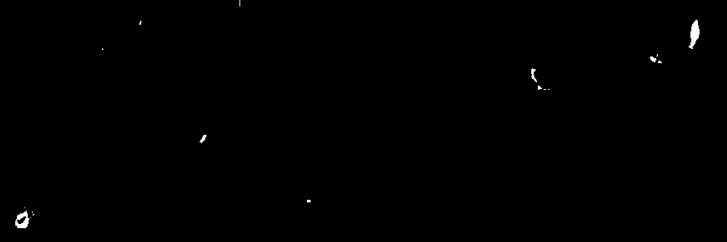


ORNL/ENU/TM-14

Contract No. W-7405-eng-26

ORNL Engineering Division

HEAT TRANSFER STUDIES IN SALT AND GRANITE

R. A. Just

Date Published: October 19/8

NOTice This document contains information of o preliminary nature. It is subject to revision or correction and therefore does not i doresent a fingl report.

OAK RIDGE NATIONAL LABORATORY

Oak Ridge, Tennessee 37830 nperated by UNION CARBIDE: CORPORATION

for the DEPARTMENT OF FNERGY

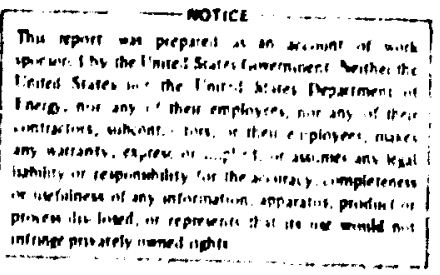




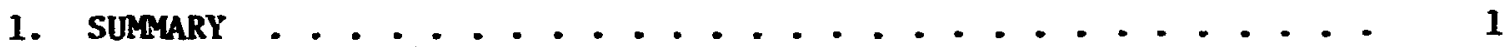

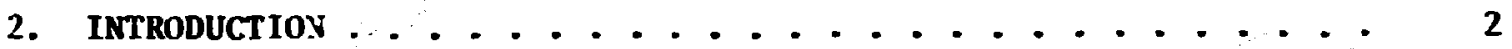

3. SOLUTION TECHKIQUE . . . . . . . . . . . . . . 7

3.1 Thermal thocel . . . . . . . . . . . . . . . 7

3.2 Thermal Uplitic Model ................. 8

4. HEAT SOURCES AND DECAY RATES . . . . . . . . . . . 10

5. ENERGY SUPELIEd TO THE FORLATION . . . . . . . . . 12

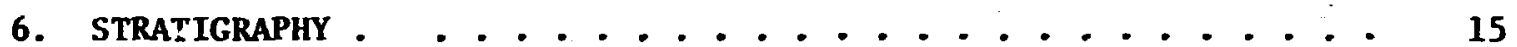

7. THERMAL-PHYSICAL PROPERTIES . . . . . . . . . . 16

8. BOUNDARY AND INITIAL CORDITIONS . . . . . . . . . . . . . . 19

8.1 Isothermal Boundary Condition . . . . . . . . . . . 19

8.2 Geothermal Heât Flux ................. 19

8.3 Radiation bowitiry Condition for the Near-Field Analysis .................. 20

8.4 Initial Conditions .................... 21

9. NEAR-FIELD MODELS . . . . . . . . . . . . . . 21

9.1 Burial Models . . . . . . . . . . . . . . . . . 22

9.2 Near-Field Results . . . . . . . . . . . . 27

10. FAR-FIELD MODELS. . . . . . . . . . . . . . . . . 33

10.1 Single-Level Far-Field Models ............. 34

10.2 Multi-Level Far-field Models . . . . . . . . . . . 34

10.3 Comparisun of Maximum Average Temperature increases . . . . 43

10.4 Comparison of Maximum Thermal Upiffe . . . . . . . . 44

11. COMPARISON OF THERMAL PROFILES . . . . . . . . . . . 48

11.1 Single and Multi-Level Reposftories............ 48

11.2 Effect of Repository Material Properties . . . . . . 49

12. CONCLUS IONS AND RECOMMENDATIONS . . . . . . . . . . . . 30

13. REFERENCES ......................... 52

APpendix A. THERMAL CONTOUR PIOTS FOR WASTT, BURIAI, IN SAIT . . . . 55

AppendiX B. THERMAL CONTOUR PIOTS FOR BURIAL, OF WASTE. IN

GRINITF. . . . . . . . . . . . . . . 69 


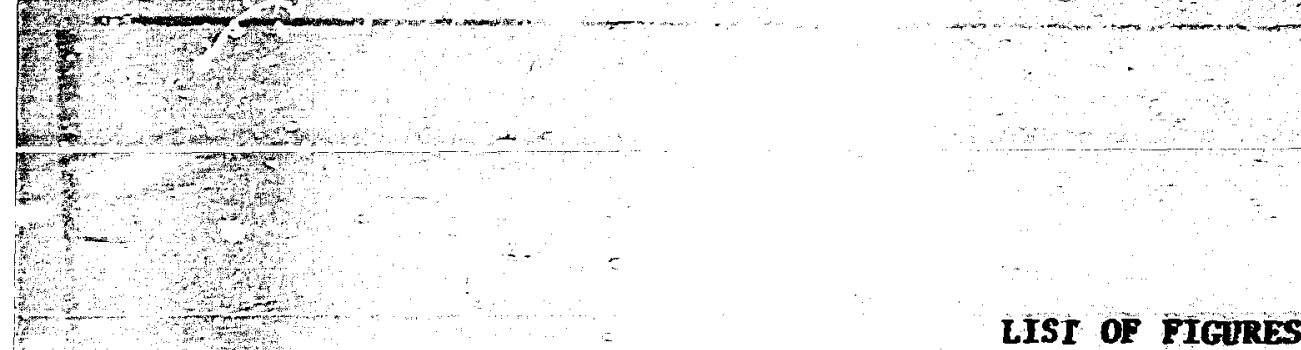

Figure

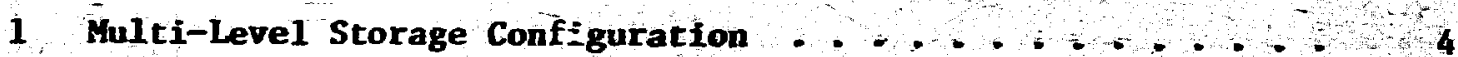

2 Single-Level Storage Configuration,,,,,,,,,---+---+- 5

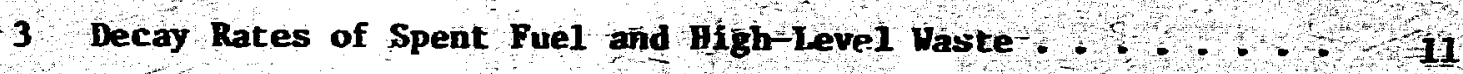

4. Total Enyrgy Supplied to the Rock Mass Per Cenister $\cdot+\cdots+,+13$

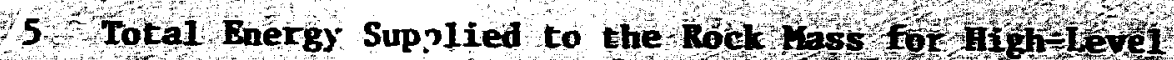
Haste and Spent Fuel at Areal Load Ings of 150 thiacte and 60 kN/acre $+2$

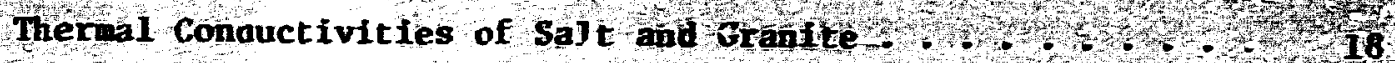

1 Near-Field Single-Leve: Thermal yodel for storage of Spent-Fuel in Granite . . . . . . . . . . . . . . 23

8 Near-Field Single-Level Thermal Model for Storago of

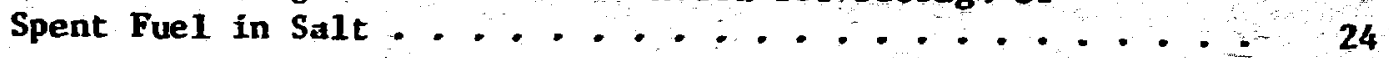

9 Near-Field Single-Level Thermal Model for Storage of High-Level Waste in Granite .................

10 Near-Field Single-Level Thermal Model for Storage of

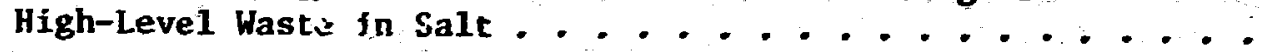

11 Near-Field Multi-Level Thermal Model for Storage of Spent Fuel in Granite ....................

12 Near-Field Hulti-Level Thermal Model for Storage of Spent Fuel in Salt ......................

13 Near-Field Multi-Level Thermal Model for Storage of High-Level Waste in Granite .................

14 Near-Field Multi-Level Thermal Model for Storage of High-Level Waste in Salt...................

15 rar-Field Single-Level Thermal Model for Storage of Spent Fuel in Grantte ...................

16 Far-Field Single-Level Thermal Model for Storage of Spent Flel in Salt .....................

17 Far-Field ingle-Level Thermal Model for storage of High-Level Waste in Granite 
19 Far-Field Single-Level Theral wdel for storage of High-Level Waste in Salt $\ldots+, \ldots,+,+,-,+,+,+$,

19 Far-Field Multi-Level Thermal Hodel for Storage of Spent Fuel in Granite $, \ldots, \ldots,-,+,+, \ldots, \cdots,+$,

20 Par-Field Multi-Level Therad Hodel for Storage of

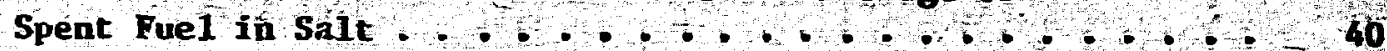

21 Far-Field Kulti-Level Theral toilel for storage of

High-Level Naste in Grante

Far-Field Hult -Level Ther hl Yodel for stortage of

High Level Waste in Salt: $,, \ldots, \ldots, \ldots$, ?

Therwal Uplift in Granite

25 Isothermal Plot at 1 Year for High-Level Waste Buried in Salt at an Areal Loading of $180 \mathrm{~kW}$ per Acre Using a Single-Level Buŕial Configuration . . . . . . . . .

26 - Isothermal Plot at 5 Years for High-Level Waste Buried in Salt at an Areal Loading of $180 \mathrm{kH}$ per Acre Using a Single-Level Burfal Configuration . . . . . . . . .

27 Isothermal Plot at 50 Years for High-Level Waste Burfed in Salt at an Areal Loading of $180 \mathrm{~kW}$ per Acre Using a Single-Level Burial Configuration .............

28 Isothermal Plot at 1 Year for High-Leve' Waste-Buried in Salt at an Areal Loading of $180 \mathrm{~kW}$ per Acre Using a Multi-Level Burfal Configuration...............

29 Zsothermal Plot at 5 Years for High-Level Waste Burfed in Salt at an Areal Loading of $180 \mathrm{~kW}$ per Acre Using a Multi-Level Burial Conffguration ..............

3!) Isothermal Plot at 50 Years for High-Level Waste Buried in Salt at an Areal Loading of $180 \mathrm{kH}$ per Acre Using a Multi-Level Bu:fal Conf fguration .............

31 Isothermal Plot at I Year for Spent Fut 1 Buried in Salt at an Areal Loading of $90 \mathrm{~kW}$ per Acre Using a SingleLevel Burfal Configuration ..................

32 Isothermal P1ot at 5 Years for Spent Fuel Buried in Salt at an Areal Loading of $90 \mathrm{~kW}$ per Acre Using a Single-LeveJ Burfal Configuration 
33 Isothermal Plot at 50 Years for Spent Fuel Buried in Salt at an Areal Loadeng of $90 \mathrm{~kJ}$ per Acre Using a

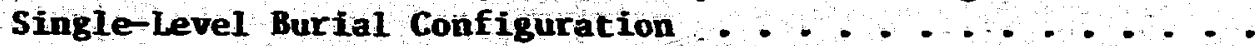

34. Isothenal Plot at 1 Year for Spent Fuel Buried in Salt at an Areal Loading of $90 \mathrm{kH}$ per Acre Using a Multilevel Burial Configuration

35 Isother a1 plot at S Years for spent Ruel burled in

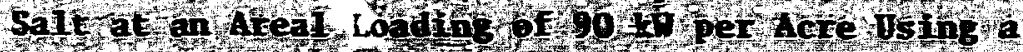
Hut terel Burtat contrifraton

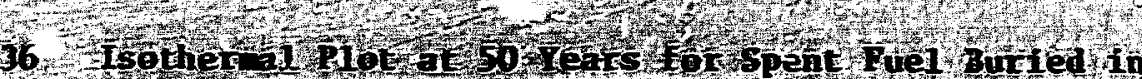

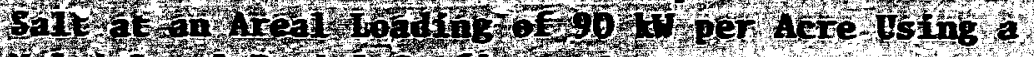

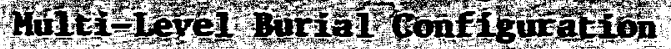

3) Isotheral Plot at 1 Tear fö̀ High-Level Waste Bursed In Granlte at an Areal loading of $180 \mathrm{~kW}$ per Acre Using a Sin̨le-Level Burial Configuration

38 Isotherinal Plot at 5 Years for High-Level Waste Buried in Granje at an Areal loading of $180 \mathrm{kH}$ per Acre Using a Single-Level Burfal Configuration..........

39 Isothermal Plot at 50 Years for High-Level Haste Buried in Granite at an Areal loading of $180 \mathrm{kH}$ per Acre Using a Single-Level Burial Configuration . . . . . . . . .

40 Isothermal Plot at 1 Year for High-Level Waste Buried In-Granfte at an Areal Loading of $180 \mathrm{~kW}$ per Acre Using a Mult-Level Burial Configuration ..............

41 Isothermal Plot at 5 Years for High-Level Waste Burfed in Granite at an Areal Loading of $180 \mathrm{~kW}$ per Acre Using a Multi-Level Burial Configuration . . . . . . . . . .

42 Isothermal Plot at 50 Years for High-Level Waste Buried in Grantite at an Areal Loading of $180 \mathrm{~kW}$ per Acre Usfing a Multi-Level Burial Configuration ..............

43. Isothermal Plot at 1 Year for Spent Fuel Buried ir. Grantte at an Areal Loading of $90 \mathrm{~kW}$ per Acre Uøing a Single-Level Burial Configuration .............

44 Isothermal Plot at 5 Years for spent Fuel Buried in Granite at an Areal Loading of $90 \mathrm{~kW}$ per Acre Using a Single-Level Burial Configuration 
45 Isothermal Plot at 50 Years for Spent Fuel Buried in Granite at an Areal Loading of $90 \mathrm{kH}$ per Acre lising a Single-Level Burial Configuration . . . . . . . . . 79

46 Isothermal Plot at 1 Year for Spent Fuel Buried in Granite at an Areal Loading of $90 \mathrm{kH}$ per Acre Using a Multi-Level Burial Configuration . . . . . . . . . .

47 Isothermal Plot at 5 Years for Spent Fuel Buried in Granite at an Areal Loading of $90 \mathrm{~kW}$ per Acre Using a Multi-Level Burial Configuration . . . . . . . . . .

48 Isothermal Flot at 50 Years for Spent Fuel Buried in Granite $=i c$ an Areal Loading of $90 \mathrm{~kW}$ per Acre Using a Mulci-Level Burial Configuration . . . . . . . . . . 



\section{FOREWORD}

This report was prepared by the Engineering Division of Union Carbide Corporation, Nuclear Division, in cooperation with the Office of Waste Isolation and is part of the National Uaste Terminal Storage Progran. The principal objective of this program is to establish facilities in various deep geologic formations at several locations in the United States which will safeiy dispose of comercial radioactive waste. This report considers the waste to be either unreprocessed spent fuel or high-level waste. As part of the Thermal Aralysis Studies of the office of Waste lsolation, this report compares the thermal responses to the burial of spent fuel and high-level waste in hypothetical repositories in salt and granite, using both single- and multi-level burial configurations. 


\section{SURMARY}

This report presents a scoping study of the feasibility of using a multi-layer terminal repository design in both salt and granite formations to store either high-lével waste or spent fuel. Calculations have been made to determine temperature prufiles within the repository and to provide an estimate of the thermal uplift that can be expected.

Near-field models developed to compare temperature profiles in the regions close to the waste canisters indicated that maximum thermal gradients and maximum temperature increases could be significantly reduced by changing from a single to a multi-layer repository design. For both high-level waste and for spent fuel, the maximum temperature

- increase in the multi-level repositories was reduced to approximately $60 \%$ of the temperature increase predicted for the single-level repositories at the same areal loading.

After the near-field models had verified that maximum thermal gradients and temperature increases could be reduced by using a multilevel repository design, a series of far-field models was developed. The far-field models used to provide qualitative comparisons of the maximum thermal uplift Indicate that the thermal uplift is roughly proportional to the energy supplied to the formation. Changing from a single- to a multi-layer repository but keeping the areal loading constant results in increased thermal uplifts. 


\section{INTRODUCTION}

Greni:- formations have been proposed as an alternative to salt formations for use as terminal repositories for spent fuel (SF) and highlevel waste (HLW). Because excavation costs in hard rock, such as granite, are substantially greater than those in salt, it has been suggested that a multi-level storage concept, in which a number of waste canisters are buried in a single vertical hole, could be used to reduce excavation costs. It may be possible to increase the permissible areal heat loads without adverse effects either on the envirorment or on containment integrity.

Energy generated by the decay of the radioactive waste is dissipated into the surrounding medium by conduction and is transmitted to the surface of the earth wher? it is released into he atmosphere. As the energy is released into the geologic formation. temperatures increase within the medium. These increased temperatures cause adverse structurai, thermal, and environmental effects, such as decreased thermal conductivity, accelerated creep rate, and increased thermal uplift. The decreased thermal conductivity will cause increased temperatures and tinermal gradients, which in turn cause increased thermal stresses. Accelerated creep of the formation leads to accelerated room closure: Thermal uplift, caused by thermal expansion of the rock mass, can have adverse effects on the integrity of the containment and on tile environment. To maintain structural integrity within the repository and to attain an acceptable environment impact, ft 1 s necessary to limit the encrgy release into the formation. Limiting the energy release also 
Iimit, the temperature gradients, temperature increases, and thermal uplift within the rock mass, as these effects are approximately proportional to the energy release.

The purpose of this study is to determine the feasibility of a multi-level burial scheme in a granite formation. The multi-level burial scheme used in this study, which assumes three waste canisters located in a single vertical hole with $100 \mathrm{ft}$ of concrete fill between the canisters, is shown in Fig. 1.

The temperature profile and therral uplift predicted for the singielevel repository concep. shown in Fig. 2 are compared with the results calculated for the multi-level scheme at the same areal loading, so that the effects of multi-level storage may be estimated. Repositories in salt formations are also analyzed for purposes of comparison with repositories in granite formations.

Vertical dispersion of the heat source, resulting from a multilevel storage concept will yield a lower volumetric heat-generation rate, as a larger volume of waste is assum:d to release the same amount of energy. The reduced volumetric heat-generation rate, coupled with an increased heat transfer area, will result in lower maximum temperatures in a multi-level repository.

This scoping study develops repository models for hypothetical salt and granite formations. Although the properties and stratigraphy may be typical of actual sites, the models do not represent any particular site. ine hypothet fcal. repositories are assumed to cover a circular area of 2000 acres ( $5266 \mathrm{ft}$ radils). Mine construction is assumed to be room and pillar, with the room floor at a depth of $2000 \mathrm{ft}$. Sixty-foot-wide 


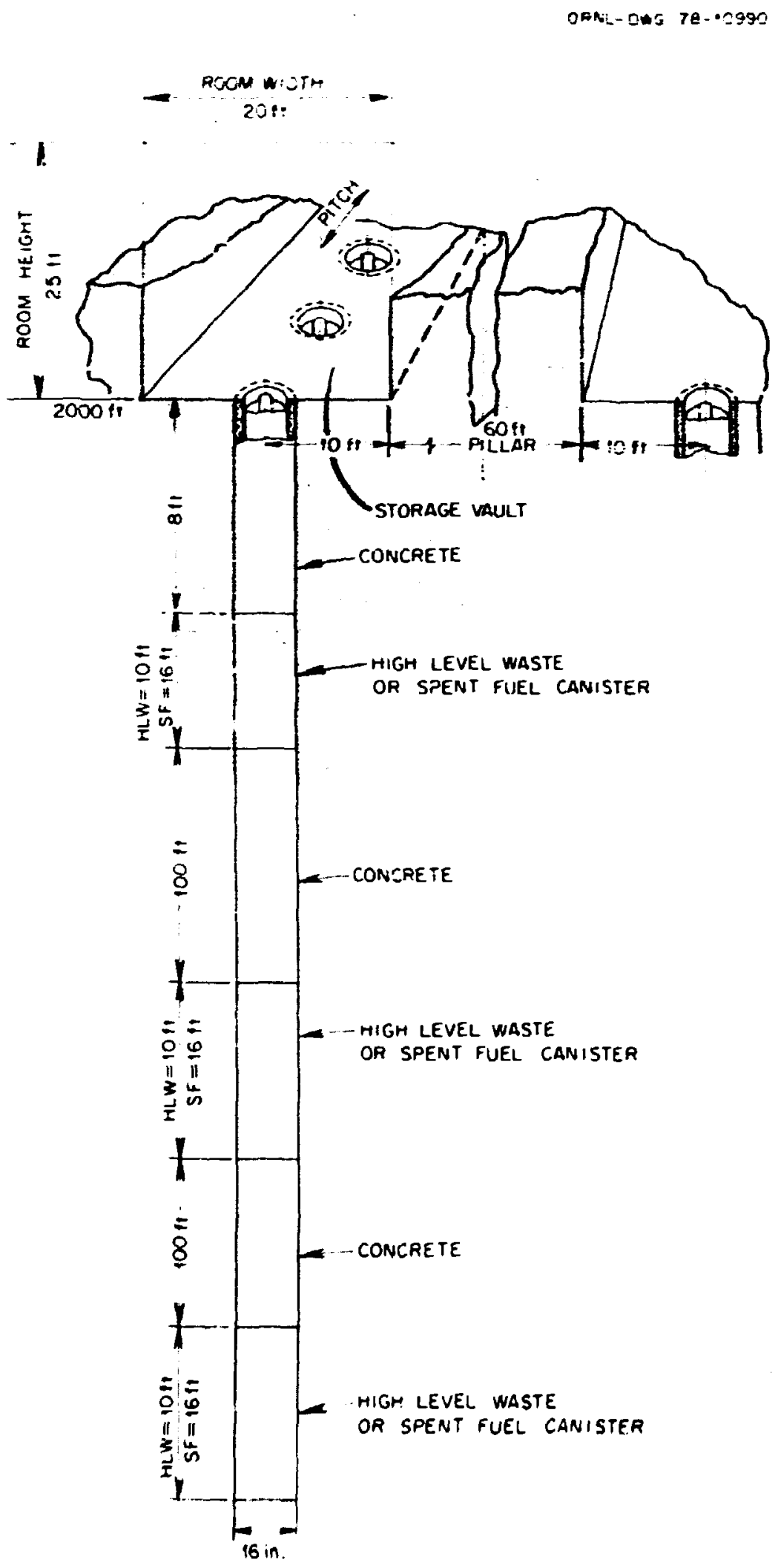

Fig. 1. Multi-level Storage configuration. 
ORNL-OWG 78-10991

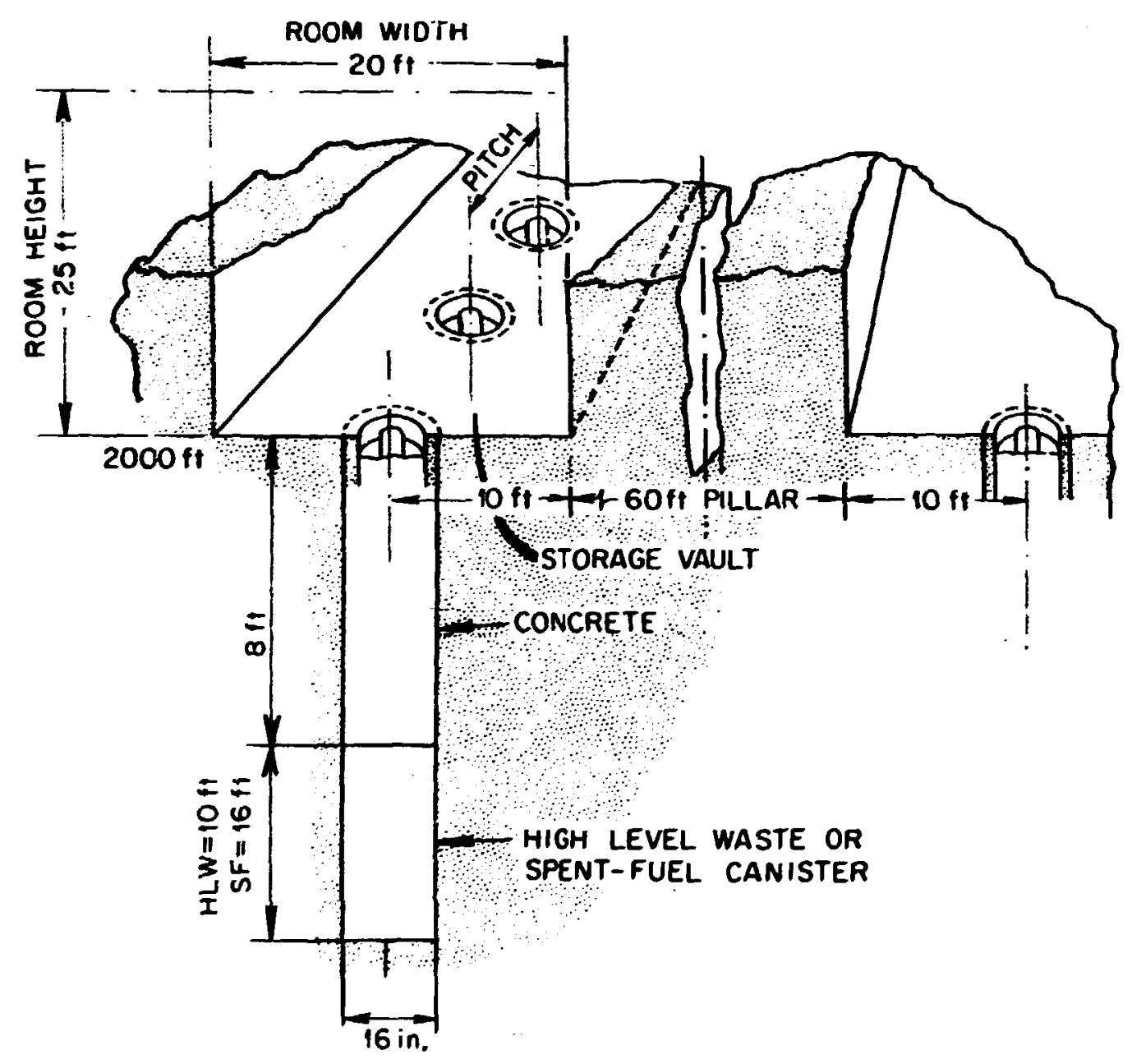

Fig. 2. Single-Level Storage Configuration. 
pillars separate roons 25 feet high by 20 feet wide. haste canisters are buried $\dot{b}$ il vertica! holes in the floor so that the highest canister is $\mathrm{S} f \mathrm{f}$ below roon floor level. Concrete is used to backfill the hc'e up to room floor level and $t$ separate the canisters in the multilr.vel storage conceprs.

Two-dimensional, cartesian, near-field thermal models were developed for qualitatize comparisons of pillar temperatures and local temperatures in the media surrounding the waste, ans far-field modeis of the entire repository were developed so that comparisons of rhermal uplifts for the dit cerent burial schemes could be made. 


\section{SOLUTION TECHNIQUE}

A 'arge system of nonlinear partiai differential equations must be solved in order to calculate the transient. cemperature distributions resulting from the plzcemen: of a decaying heat source in a medium in which the thermal diffusivity is temperature dependent. HEATING5, a general purpose, finice-difference, heat rransfer code, ${ }^{l}$ was chosen to perform the thermal calculation:

\section{I Thermal Model}

h.EATING is desinged to solve steady-state and transient heat conduction problems with terperature- and spatially-dependent thermal properties as well as time-dependent heat-generation rates. Boundary conditions may be specified as adtabatic, forced convection, natural

convection, radiation, isothermal, or as constant heat flux. Variouss expicit and implicit techniques are available for the solution of transient heat conduction problems.

The flexibility of HEATING5 and the fact that the author has had extensive experience using the code led to the selection of HEAiING5 as the means of calculating temperature distributions resulting from the different repository concepts.

HEATING5 is Jesigned to solve a transient problem by numerical schemes which include the Classical Explicit Procedure, Levy's modification to the Classical Explicit Procedure, the Crank-Nicholson technique, and the Classical Implicit Procedure. Because it is stable for a time 
step of any size, the Crank-Nicholson techniqi:e was selected as the solution technique for the transient analysis.

Heat is generated within the radioactive waste material by radioactive decay. Because radioactive decay for a given waste is a sum of exponcntials with respect to time, exponential interpolation of the dec'y curves was used in an attempt to obtain more accurate results than wruld be the case for linear interpolation. Linear interpolation would orerestimate the energy for a decaying exponential. HEATING5 was modified so that exponential interpolation rather than linear interpolation of the decay curve would be made between the available data points, and a modification was made to allow a thermal uplift calculation to be made internal to the code.

\subsection{Thermal Uplift Model}

Energy generated by the decaying waste increases the temperature within the repository and results in a volumetric thermal expansion of the material. This thermal expansion causes an uplift of the rock mass in which the waste is buried. The maximum thermal uplift will be at the center of the repository, where the maximum increase in temperature within the strata will occur for the asisumed model. Because calculated uplifts :or the different repository concepts are intended to be used for qualitative comparisons only, a simnlified, conservative, onedimensional model. was formulated to calculate the maximum thermal uplfit. The uplift model is based on the assumption that the repository will be constrained within its 5266 it radtal boundary and allowed to move frecly in the axial Jirection. A constant temperature pioflle across the 
repository, equal to the maximum temperature at any given elevation, was assumed to simplify the model. The resulting highly conservative model of the tharmal uplift is expressed by

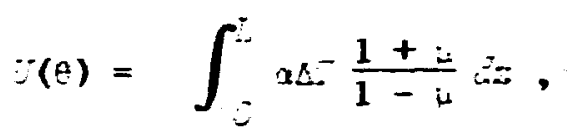

where

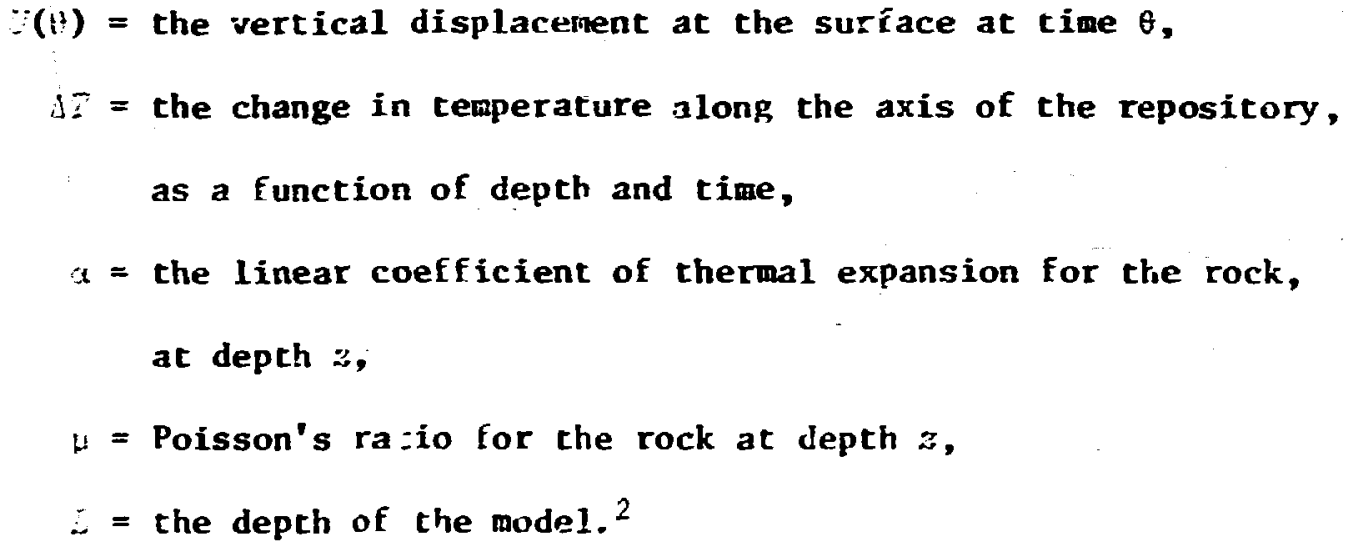

The astual calculation of the thermal uplift was made by taking the predicted temperature profile and numerically integra ing, using trapezodial integration of the above equation. 


\section{HEAT SOURCES AND DECAY RATES}

The heat sources studied are assumed to be either 10-year-old, PWR high-level waste (HLK) or PWR spent fuel (SF). A spent fuel element containing 0.4614 metric tons of uranium (MTU), is modeled as a homogeneous heai-generating region $16 \mathrm{in}$. in diameter and $16 \mathrm{ft}$ long. The high-level waste is contained in canisters $16 \mathrm{in}$. in diameter and $10 \mathrm{ft}$ long with 2.09 MTU per canister with an active length of $8 \mathrm{ft}$ at the bottom of the canister.

The time-degenoenc heat-generation rates used in this study for high-level waste and spent fuel are those calculated by $D$. W. Turner, ${ }^{3}$ through the use of the ORIGEN computer code. ${ }^{4}$ The initial heatgeneration rates at burial for the SF and HLW canisters are $0.55 \mathrm{~kW}$ and $2,2 \mathrm{~kW}$ per canister, respectively.

Normalized heat-generation rates for both SF and HLW were obtained by dividing the time-dependent heat-generation rates by their values at burial. Exponential interpolation between the data points was used to establish the normalized decay (heat-generation rate) curves shown in Fig. 3. 


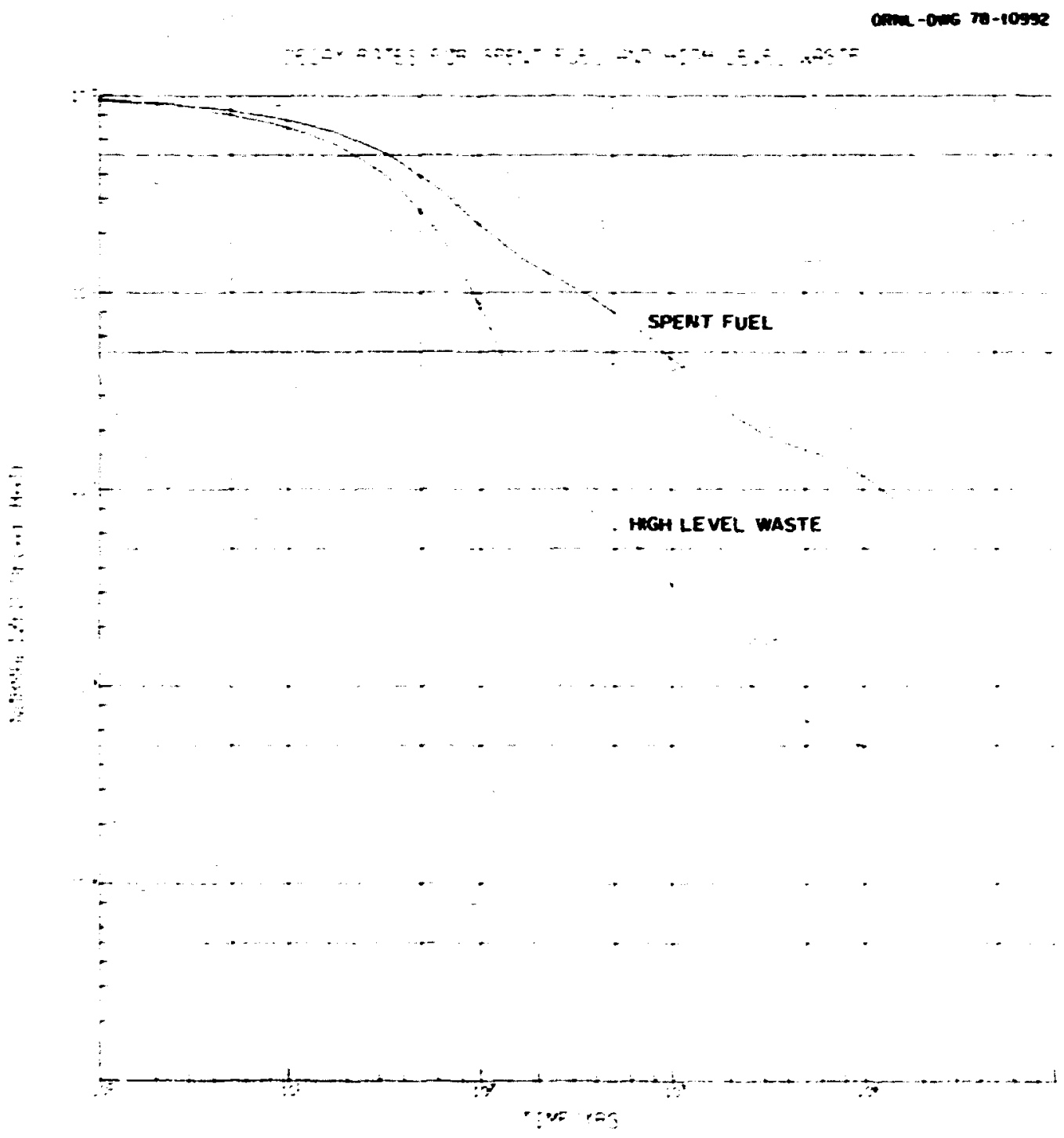

fig. 3. Necay Rates of Spent Fuel and High-Level Waste. 


\section{ENERGY SUPPLIED TO THE FORMA:ION}

Energy released by decay of HLW and SF is first absorbed by the surrounding geologic formation, and then it is conducted to the surface and released to the environment. The tutal amount of energy released from the waste to the rock mass is obtained by integration of the decay curves with respect to time.

Figure 4 shows a comparison of the thermal energy generated by it high-level waste canister to that generated by a spent-fuel ass.ambly. After approximately 3000 years, the same amount of energy has been generated by either a single canister of high-level waste or an assewbly or spent fuel.

The energy releases per acre are compared in Fig. 5 for high-level vaste and spent fuel, with areal loadings of $150 \mathrm{~kW} /$ acre and $60 \mathrm{~kW} / \mathrm{acre}$, respectively. The same amoun: of energy has been released by each after approximately 600 years. 
14

num-ons $70-$ roses

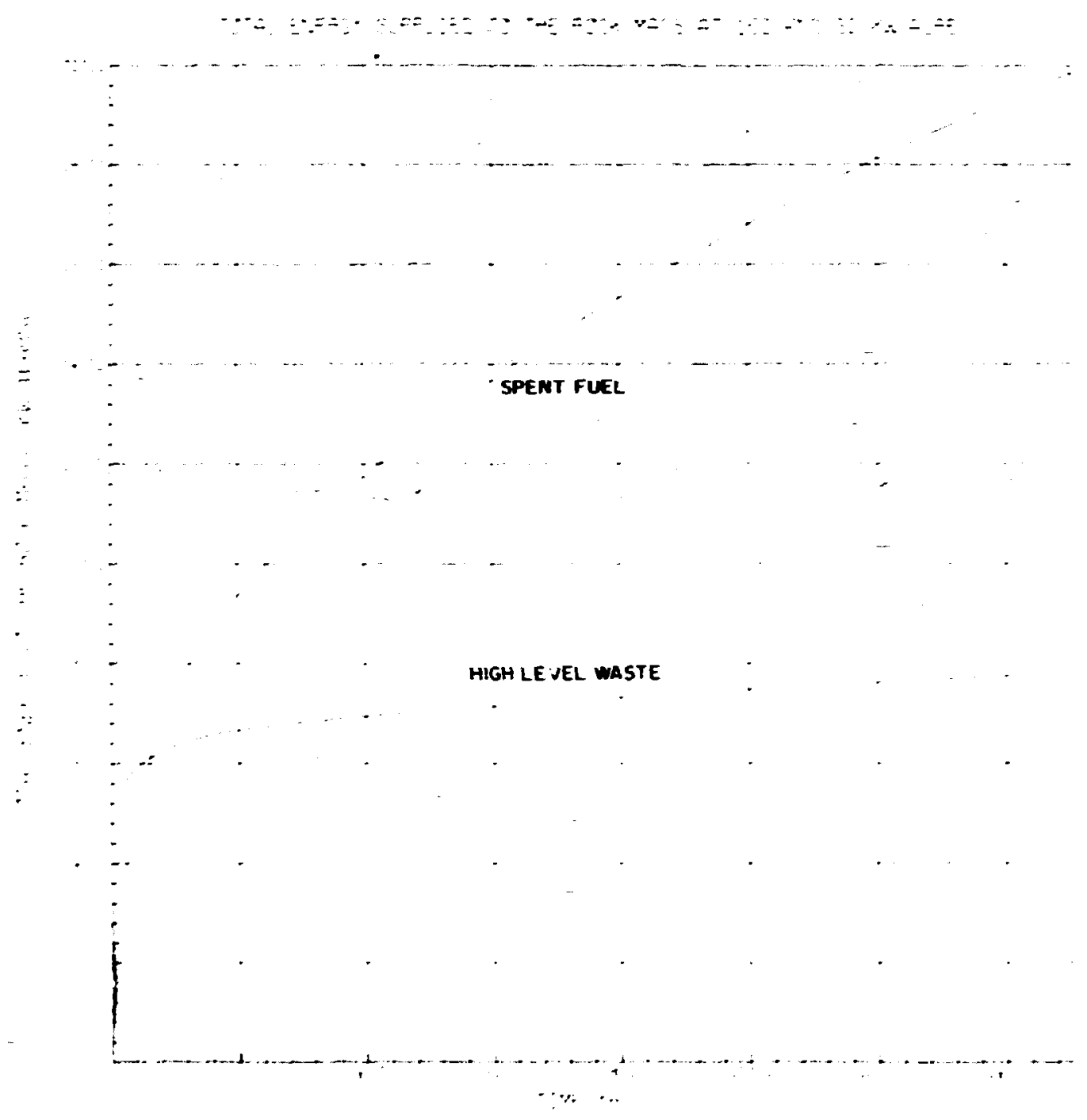

Fig. 5. To cal Energy Supplied to the Rock Mass for High-Level Waste and Spent Fuel at Areal Loadings of $150 \mathrm{~kW} / \mathrm{acre}$ and $60 \mathrm{~kW} / \mathrm{acre}$. 


\section{STRATIGRAPHY}

Hypothetical stratigraphies have been chosen for salt and for granite formations because the stratigraphy of a formation will ve sitc dependent. The salt formation is assumed to have an overburden with a constant thermal conductivity extending from the surface to a depth of $800 \mathrm{ft}$ and a homogeneous body of salt, with temperaturedependent thermal conductivity below $800 \mathrm{ft}$. The granite formation was assumed to consist of a single homogeneous budy of granite, with temperature-dependent thermal conductivity extending downard from ground level. 


\section{THERRLAL-PHY IICAL PROPERTIES}

Thermal-physical propertie:; used in this study, as summarized in Table 1, are typical properties of soil, concrete, salt, and granite. Since comparison of salt and granite repositories is part of the scope of this study, it is of interest to compare the properties of salt and granite. The thermal conductivities of salt and granite both derrease with increasing temperature, as shown in Fig. 6. Because the thermal conductivity of salt is approximately twice that of granite and it is easier for energy to diffuse away from the waste in salt than in granite, lower remperatures would be expected in salt. Salt, however, has a coifficient of thermal expansion approximately five times that of granite. 
Table 1. Therme-physlial properties

\begin{tabular}{|c|c|c|c|c|c|c|c|}
\hline Macerial & $\begin{array}{c}\text { Temperature } \\
\left({ }^{\circ} \mathrm{F}\right)\end{array}$ & $\begin{array}{c}\text { Thermal } \\
\text { conduct } 1 v 1 t y \\
\left(B t u / h r \cdot f t 0^{\circ} \mathrm{F}\right)\end{array}$ & $\begin{array}{l}\text { Density } \\
\left(1 \mathrm{~b} / \mathrm{t}^{3}\right)\end{array}$ & $\begin{array}{c}\text { Heial sapiaclly } \\
(B t w / 1 \mathrm{~b} \cdot \bullet \mathrm{F})\end{array}$ & $\begin{array}{c}\text { Polsson's: } \\
\text { Riltlod }\end{array}$ & Imlshlvily" & 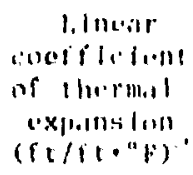 \\
\hline Grandte & $\begin{array}{r}32 \\
122 \\
212 \\
392\end{array}$ & $\begin{array}{l}1.61 \\
1.51 \\
1.43 \\
1.33\end{array}$ & 165 & 0.2 & 10.15 & 0,45 & $\begin{array}{c}4.3 \cdot 10^{-6} \\
\end{array}$ \\
\hline Salte: & $\begin{array}{r}32 \\
122 \\
212 \\
302 \\
392 \\
482 \\
572 \\
662 \\
752\end{array}$ & $\begin{array}{l}3.53 \\
2.90 \\
2.43 \\
2.08 \\
1.80 \\
1.60 \\
1.44 \\
1.33 \\
1.20\end{array}$ & 135 & $n .2$ & 0.4 & 11.9 & $23.5 \cdot 10^{-4}$ \\
\hline Coner- $\therefore$ & & 0.5 & 125 & 0.21 & & & \\
\hline Warburden: & & 1.0 & 120 & 0.2 & 0.2 & & $4 \cdot 10^{-6}$ \\
\hline
\end{tabular}

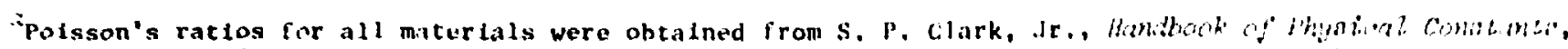
Geological Soriety of Amerlica, New York, 1966.

"The thermal emissivities of salt and granite are arsumed values.

"The coefficients of thermal exransion for salt and grantte were ohtalned from s. P. Clark, Ir., i.m.

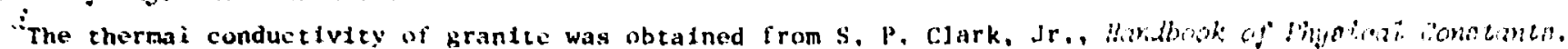

"The density and spectif le heat of grante were obtained from A. J. Chapman, Hiat Tuanafer, Marmlllim. Now York, 1974.

"The thermal conductivity of salt was obtalned from F, Blroh and H. Clarke, Am, a. Sai, 238: 613-35 (1940).

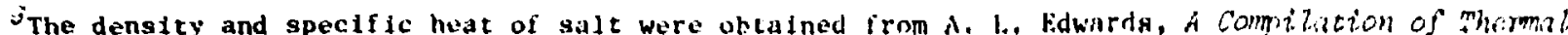

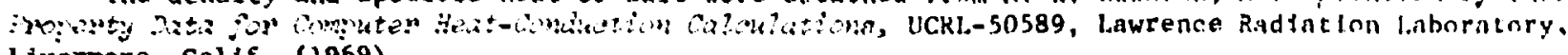
Livermore, calif. (1969).

'Thermal properties of concrete were obtained from $A$. I. Chapman, Heat tranafer.

All properties of the overburden are assumed values. 


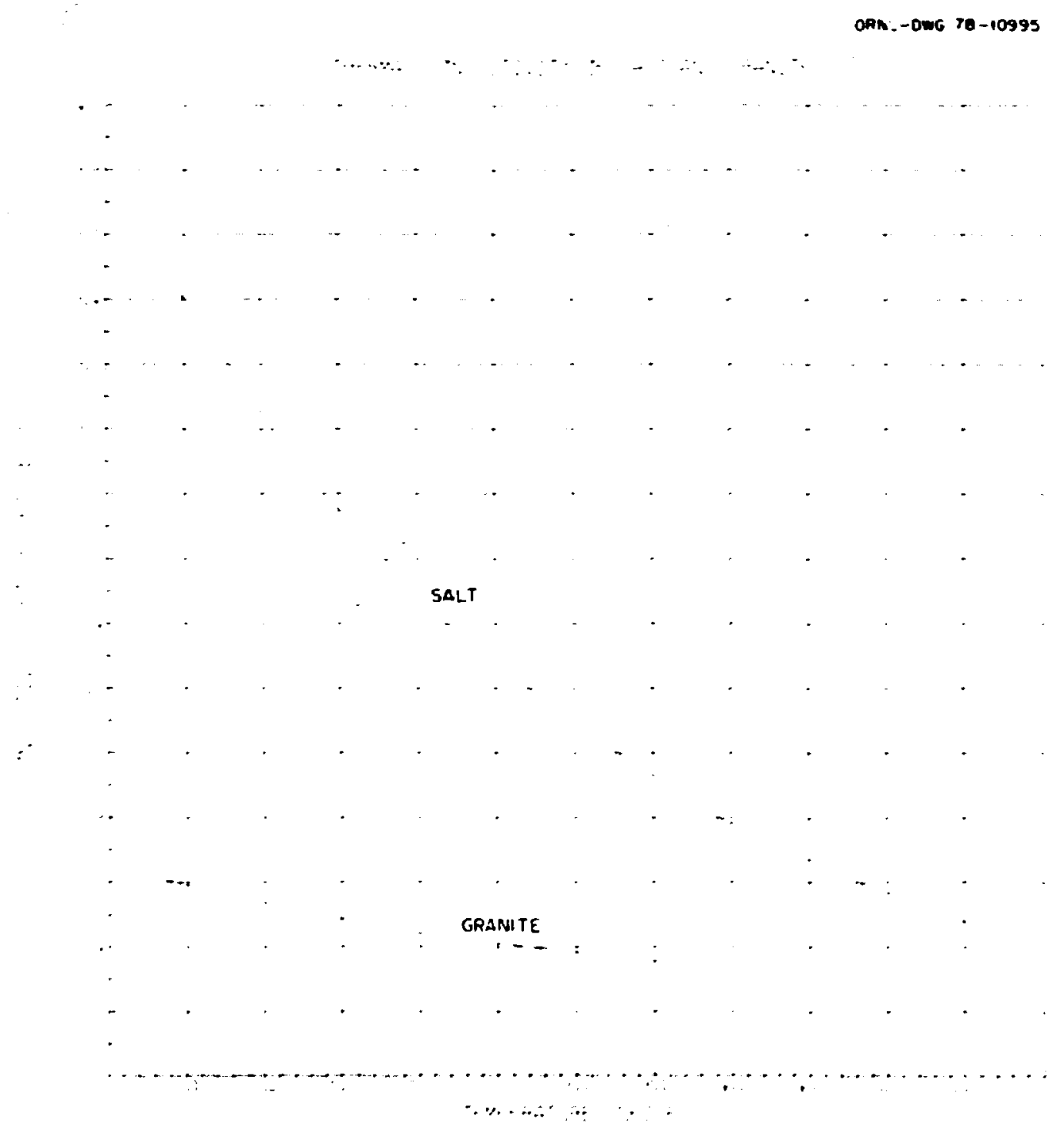

Fig. 6. Therna: conductivities of salt and cranite. 


\section{BOUNDARY AND INITIAL CONDITIONS}

Boundary conditions specified sor both the near- and far-field models used in this study include the ground-level surface temperature and the geothermal heat flux. A radiative boundary condition was also applied across th? room in the near-field models.

\subsection{Iscthermal Boundary Condition}

Ground level surface temperatures are subject to both diurnal and seascnal fluctuations. Observations have shown that these fluctuations decrease with depth and that they are negligible at depths below $50 \mathrm{ft} .5$

Thermal transfents included in this study span time frames of up to 7500 years. It is clear that time steps significantly greater than one year must be used to obtain solutions that are econowically feasible. However, if time steps greater than one year are used, it becomes impossible to model the diurnal and seasonal pertubations in the ground surface temperature. Therefore, it ras decided to assume a constant surface temperature of $60^{\circ} \mathrm{F}$, which is approximatily the mean surface temperature within the continental United States. ${ }^{6}$ This assumption should not serfously limit the usefulness of the results of the study.

\subsection{Geothermal Heat Flux}

The geothermal heat flux is site dependent. Therefore, the mean goethermal heat flux $\left(0.0167 \mathrm{Btu} / \mathrm{hr} \cdot \mathrm{ft}^{2}\right)$ for the continental united States 6 was used in this analysis and was imposed on the lower (zdirection) boundary of all heat transfer models used in this report. 
8. 3 Radiation Boundary Tondition for the Near-Field Models

A significant amount of heat is transferred by radiation heat transfer among the floor, walls, and ceiling of the room. Because HEATINCS cannot wodel radiation heat transfer between nonparallel surfaces, the radiation heal transfer from tne walls to the floor and ceiling was neglected.

Radiation heat transfar is dependent on the surface conditions and materials of the radiating surfaces as well as on the geometry of the surfaces. The geometrical dependence is expressed in terms of a radiation shape or view factor, and the surface properties are included in the thermal emissivities of the surfaces.

A radiation view factor of 0.35 was calculated for two infinitely long parallel planes, $20 \mathrm{ft}$ wide, which are separated by a_distance of $25 \mathrm{ft}$. Thermal emissivities of 0.9 and 0.45 were assumed for the radiating salt and granite surfaces, respectively.

\subsection{Initial Conditions}

Initial conditions were established by calculation of the steadystate temperature profile that existed within the formation before excavation had begun. The steady-state profile was established by appiying a geothermal heat flux the base of the model and an fsothermal bounlary condicion at ground level. 


\section{NEAR-FIELD MODELS}

Two-dimensional, $x-z$, cartesian, near-field thermal models developed for comparison of the different repository concepts are intended to be used for qualitative comparisons of pillar temperatures and local temperatures in the media surrounding the waste. As shown in Figs. 1 and 2, the pitch between adjacent,rows of waste canisters is $80 \mathrm{ft}$. Symmetry of the repository makes possible development of a near-field model spanning only $40 \mathrm{ft}$. The near-field thermal analysfs was limited to a span of 50 years that covers the time in which the mine is excavated, the waste is deposited, and the mine is backfilled. Implicit to any iwo-dimensional modeJ is the assumption of uniformity in the third dimension. Therefore, formulation of a twodimensional cartesian near-field model is equivalent to the assumption that the heat-generating regfons representing the waste are infinitely long in the $y$-direction. In reality, the heat-generation regions in an actual repository are concentrated in waste canisters. The ef fect of dispersing or spreading out the heat-generating regions is to decrease the volumetric heat-generation rate in the thermal model. According1y, the near-field models will underpredict temperatures in the repository in areas close to the waste. A more accurate prediction of the temperature profile would require development of three-dimensfonal repository models, which is beyrond the scope of this study.

Pisrametric studies utflizing one-dimensional models indicated that extension of the near-field models to a depth of 5 'jJo $\mathrm{ft}$ would ensure an Iscthermal boundary throughout a 50-year transicant. 
Boundary conditions applied to the near-field models, as descrihed in Sect. 8, include a geothernai heat flux applied at a depth of $5000 \mathrm{ft}$, in isotheraal boundary cemperature applieci at ground level, and a radiative boundary condition across the room.

Radiation is the predominant mode of hcat transfer across the room.

Thersfore, it was decided to neglect conduction and convective heat transfer so that computer costs could be decreased by simplification of tue model.

Near-field models used to analyze the burial of high-lever vaste and spent fuel in both granite and siat formations are summarized in Table 2.

Tále 2. Summary of near-fiald models

\begin{tabular}{|c|c|c|c|c|c|c|c|c|}
\hline \multirow{2}{*}{$\begin{array}{l}\text { rype of } \\
\text { rodel }\end{array}$} & \multicolumn{3}{|c|}{ Spent tuel } & \multicolumn{5}{|c|}{ Hich-level waste } \\
\hline & $60 \frac{\mathrm{kh}}{\text { acre }}$ & $90 \frac{\mathrm{kW}}{\mathrm{acre}}$ & $180-\frac{\mathrm{kk}}{\mathrm{ac}: 2}$ & $1.50 \frac{\mathrm{k} k}{\mathrm{a}=\mathrm{re}}$ & 180 & $\frac{\mathrm{kW}}{\mathrm{acre}}$ & 210 & $\frac{\mathrm{kW}}{\text { acre }}$ \\
\hline Enelo-level & $x$ & $\therefore$ & & $x$ & & $\mathrm{x}$ & & \\
\hline$\because a t i-i \cos 1$ & & $x$ & $\therefore$ & & & $\mathrm{x}$ & & $\mathrm{x}$ \\
\hline
\end{tabular}

\subsection{Burial sudels}

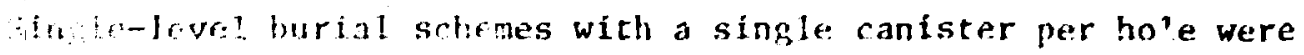

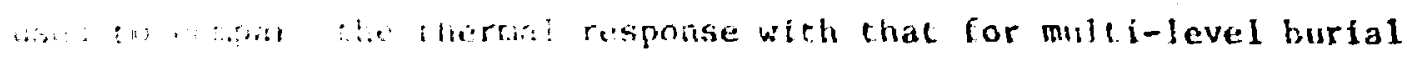

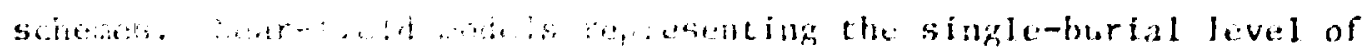

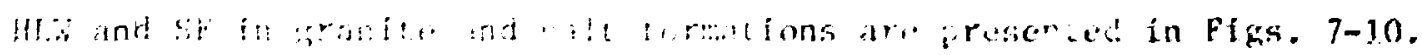

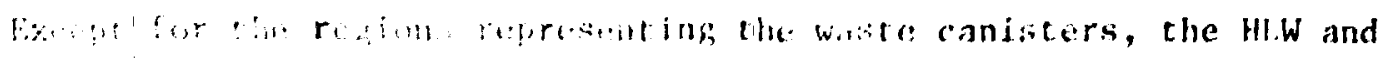
$\therefore$ nod! : ine idretirai. 


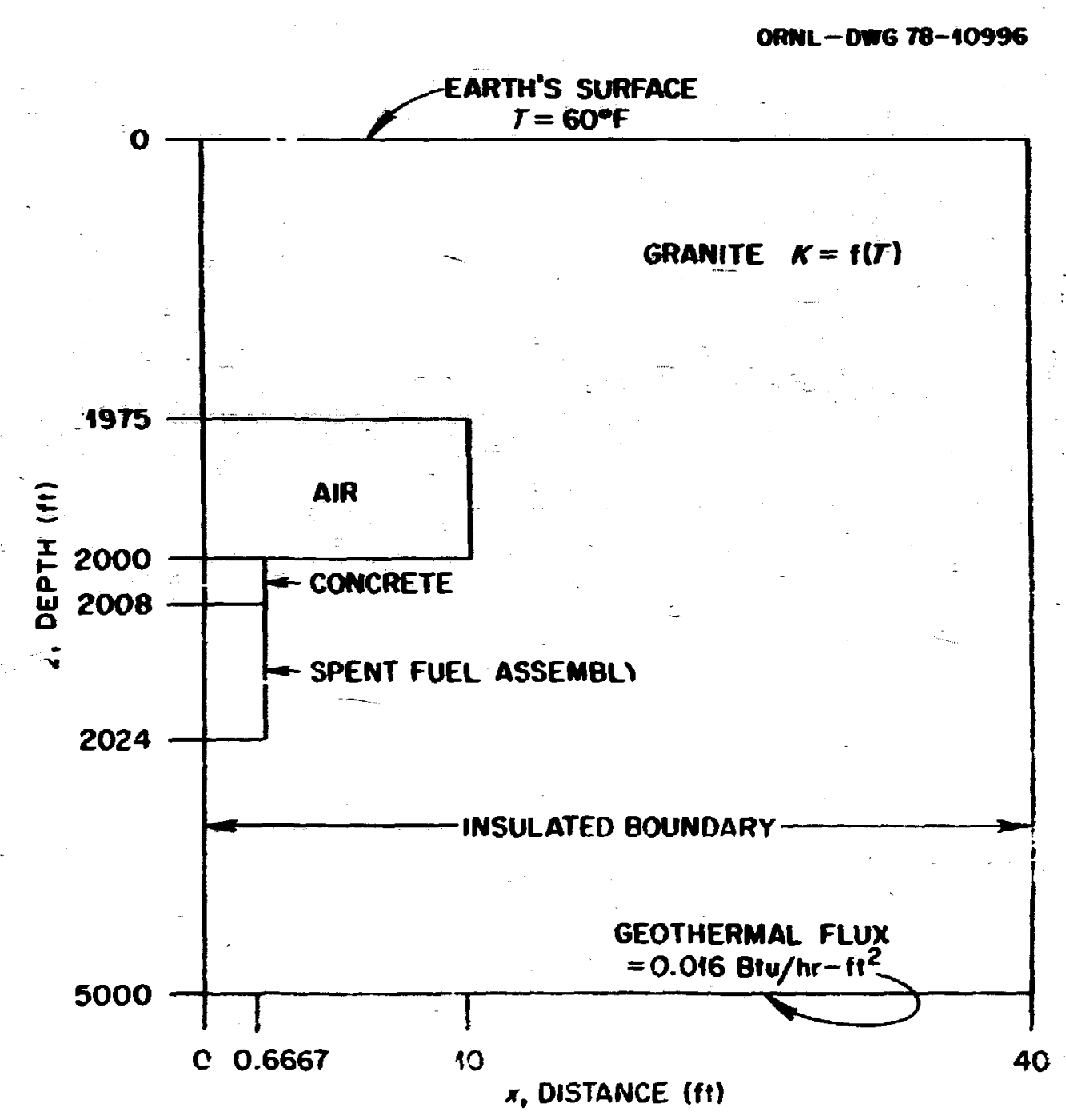

Fig. 7. Near-Field Single-Level Thermal Model for Storage of Spent Puel in Granfte. 


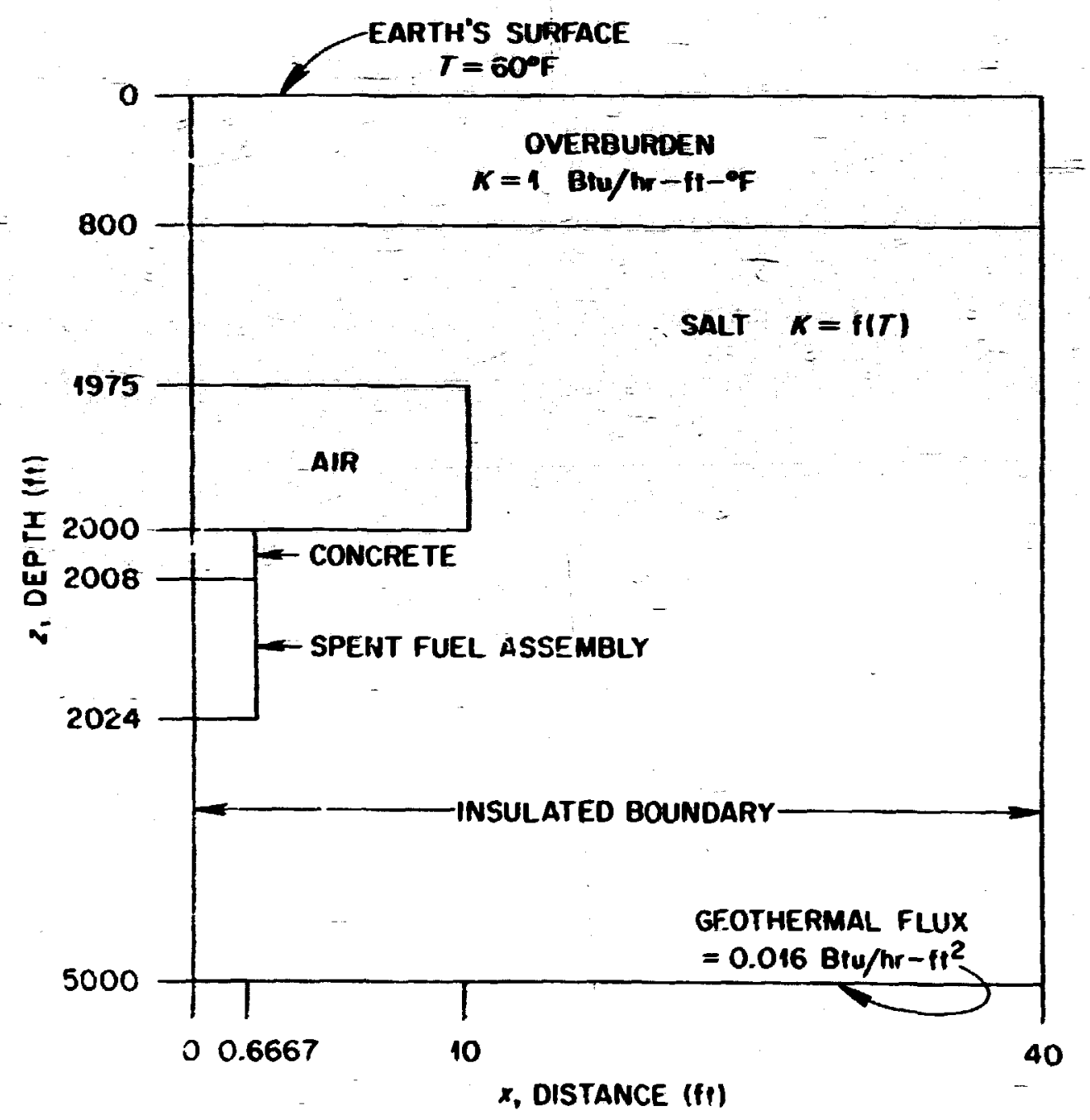

Fig. 8. Near-Field Single-Level Thermal Model for Storage of Spent Fuel in Sait. 


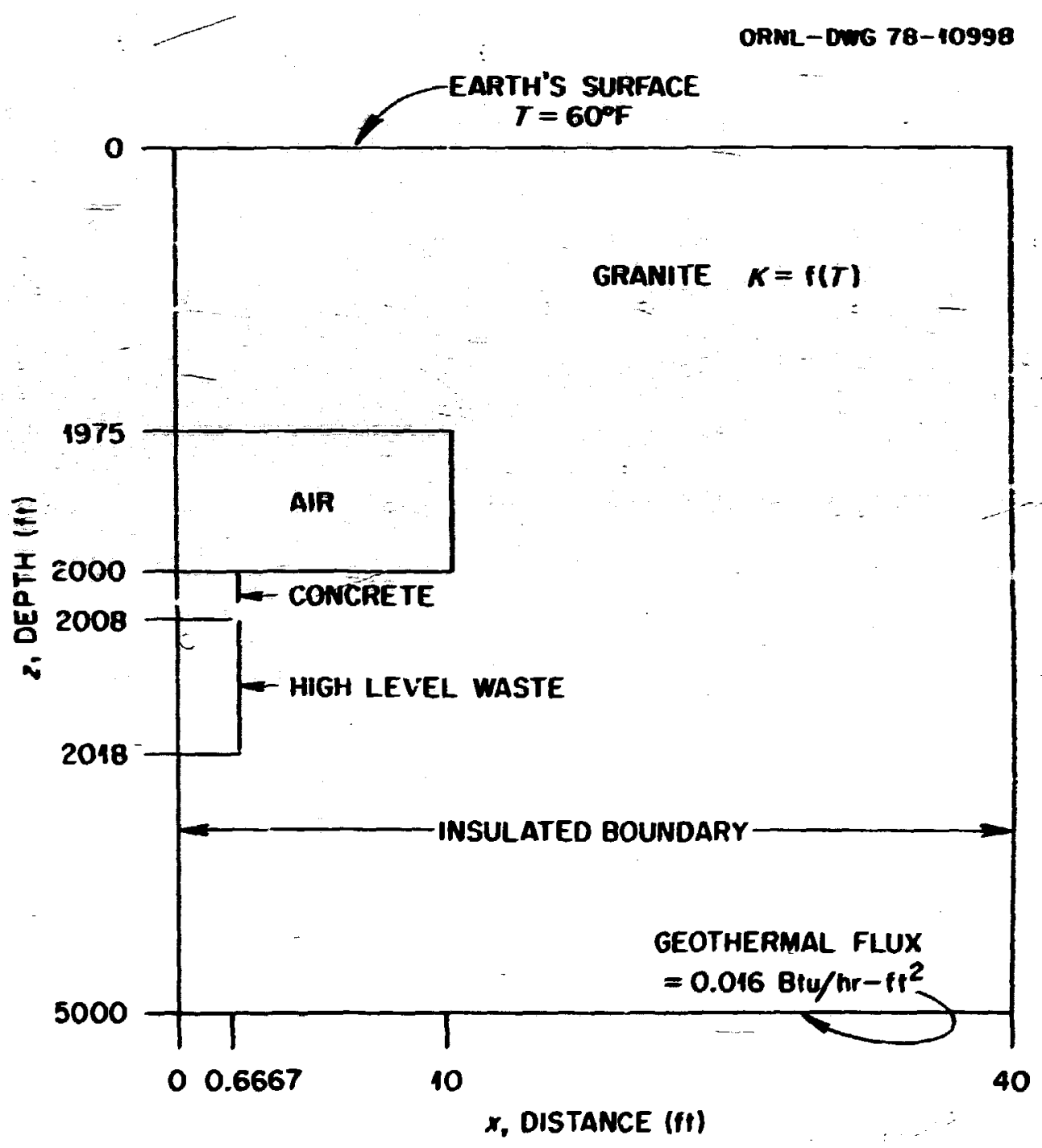

Fig. 9. Near-Field Single-Level Thermal Model for Storage of High-level Waste in Grantie. 


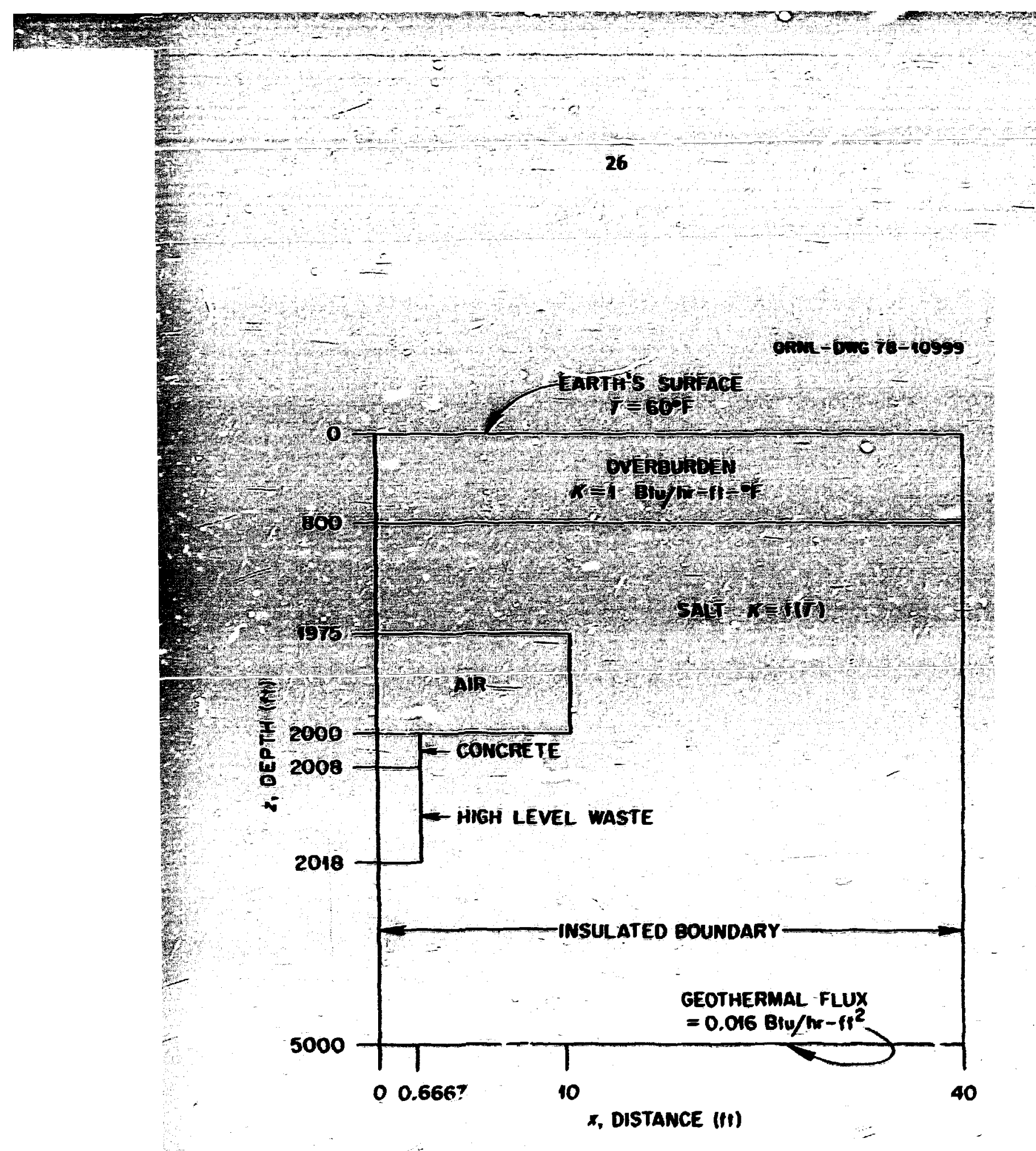

Fig. 10. Near-Field single-Level Therwal Model for storage of High-Level $K \cdot \cdots$ in Talt. 
Themal properties of the region representing the waste are assumed to be the sane is that of the surrounding geological formation. Hultlevel repository podels, as shown in figs. I1-14, consider the burial of three uaste canisters in each vertical hole, Concrete is used to cap the boles as welf as to separate the faste canisters.

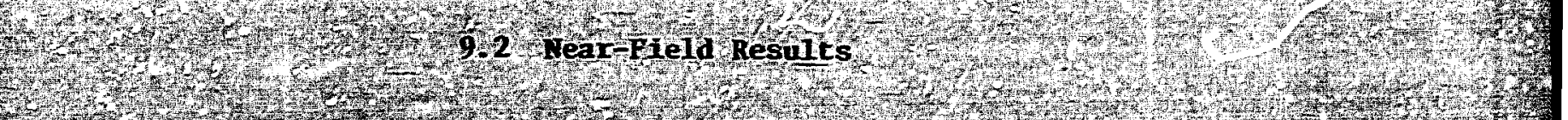

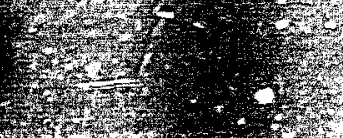

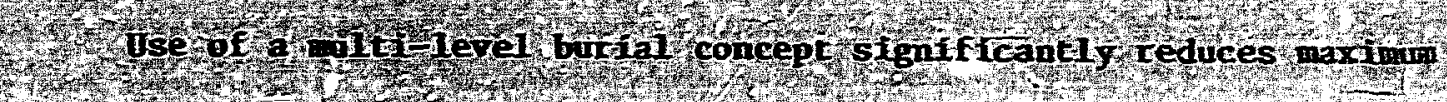
coeruge reposito 4 temperature increases for the same areal thermal loading. These maximun temperature increases occur at the canister nicplane for the single-level modeis, and at the midplane of the center canister for the auli-level models. The predtcted peak average temperature Increases in the rock formation that occur at the outer radius of the waste are sumarized in Table 3.

The magnitude and time of a peak temperature increase depend on the geometry of the thermal model, the thermal properties of the medium, and the decay rate of the vaste material. The actual time of peak average temperature increase is difficult to determine beca:sic of the smali slops. of the time-temperature curve. Therefore, the predictec time of the peak average temperature increase may be as much as 5 years in error.

The results sumarized in Table 3 show that an additional 20 years were required for the SF, single-ievel burials to reach a maximum average temperature increase, as compared to the HLW, single-level burial scheme. The additional time required for the SF to reach a maximum average temperature increase tesults from the different decay rates of SF and HLW for the same inftial thermal loading. 


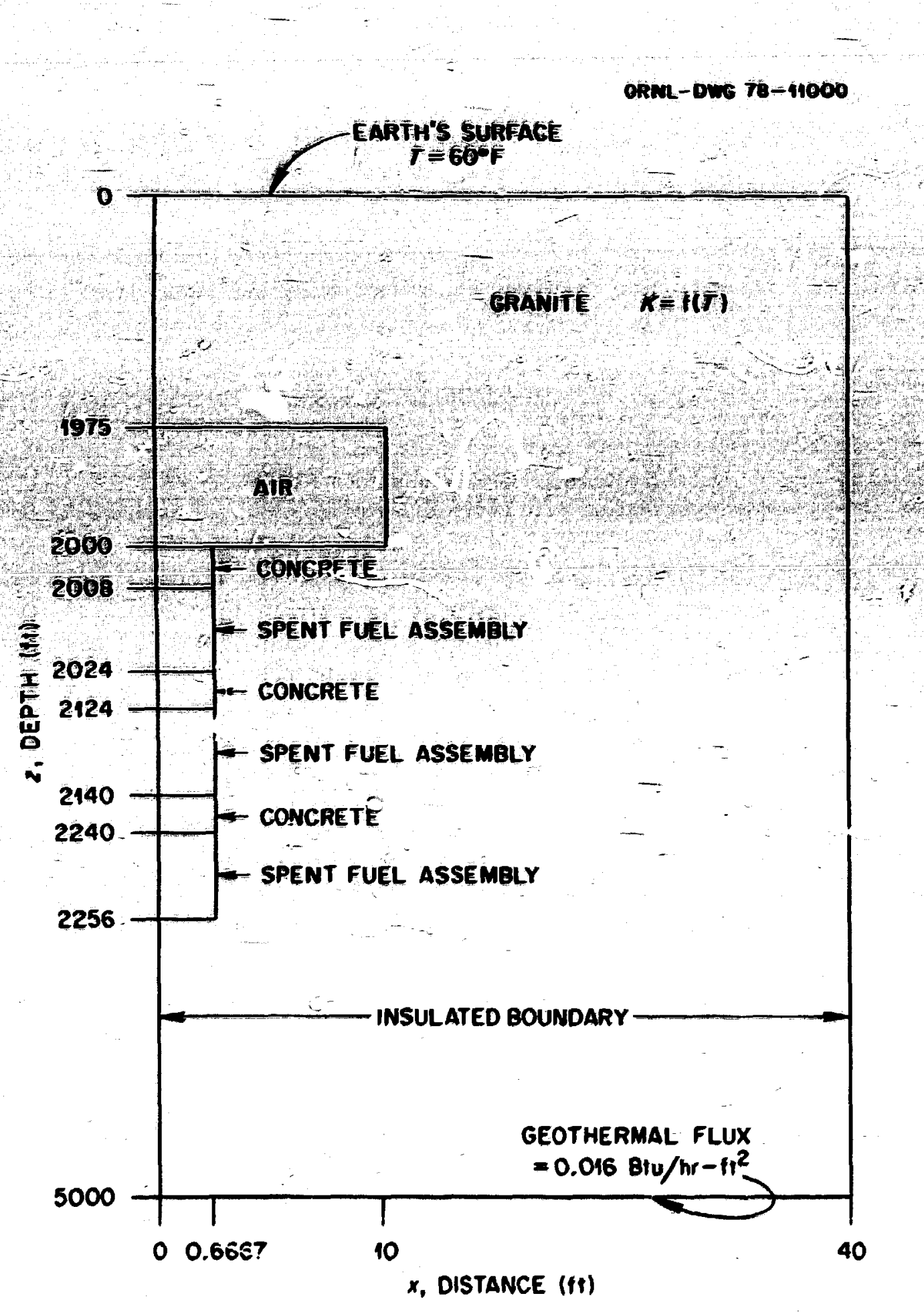

Fig. 11. Near-field Multi-Level Thermal Model for Storage of Spent Fuel in Granite. 


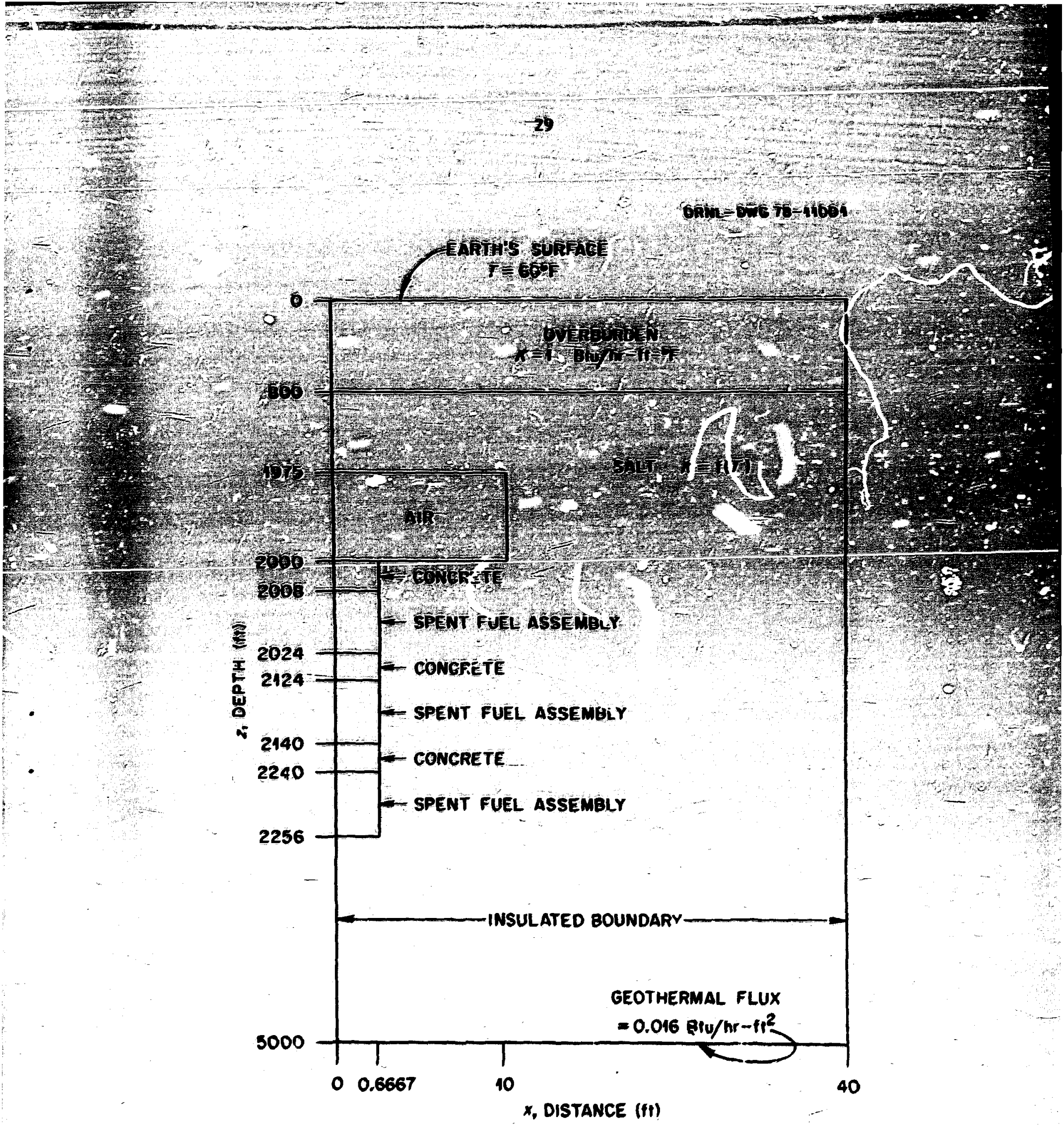

Fig. 12. Near-Field Multi-Level Thermal Model for Storage of Spent Fuel in Salt. 


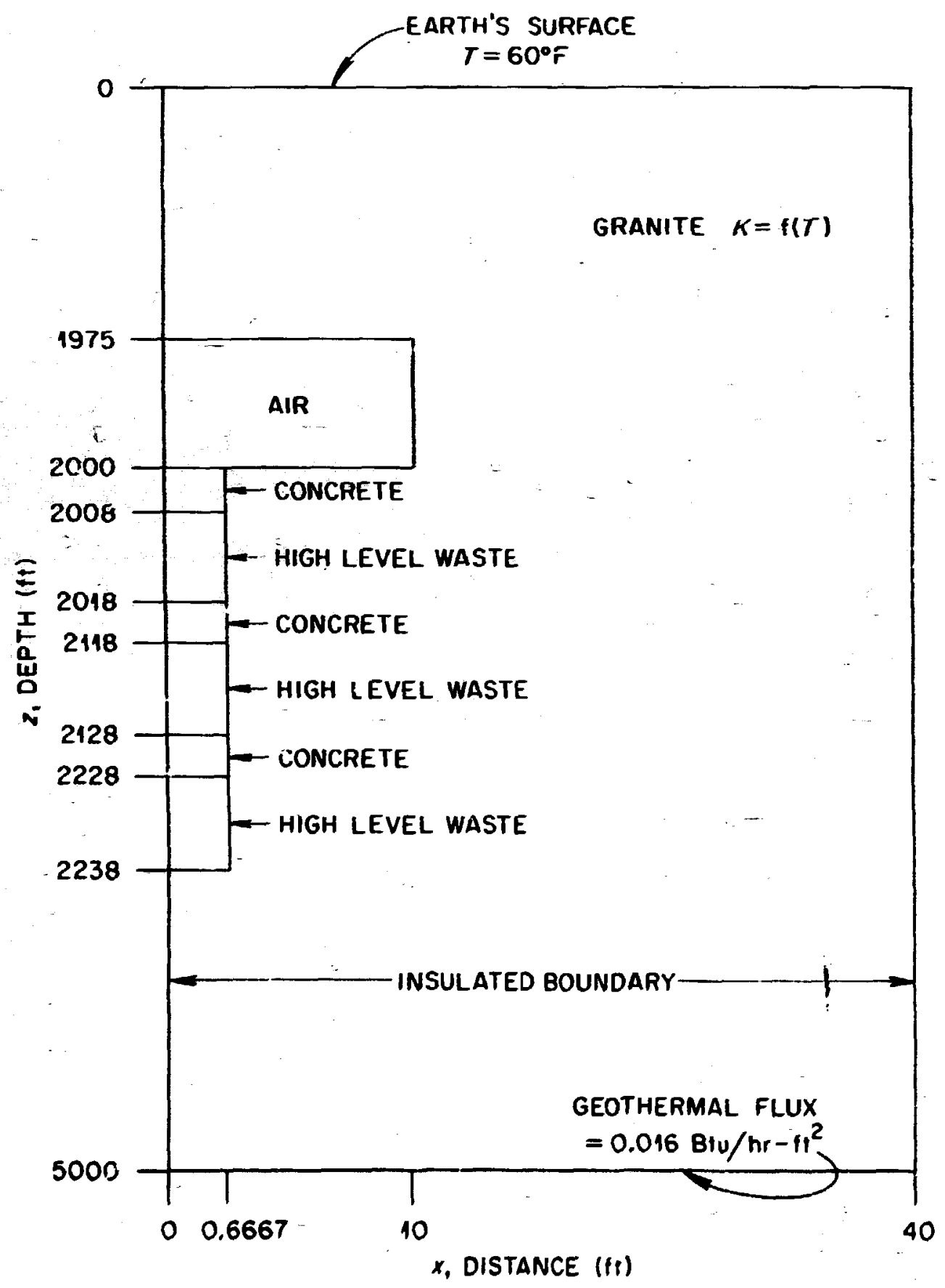

Fig. 13. Near-Field Multi-level Thermal Model for Storage of High-Level Waste in Grantie. 


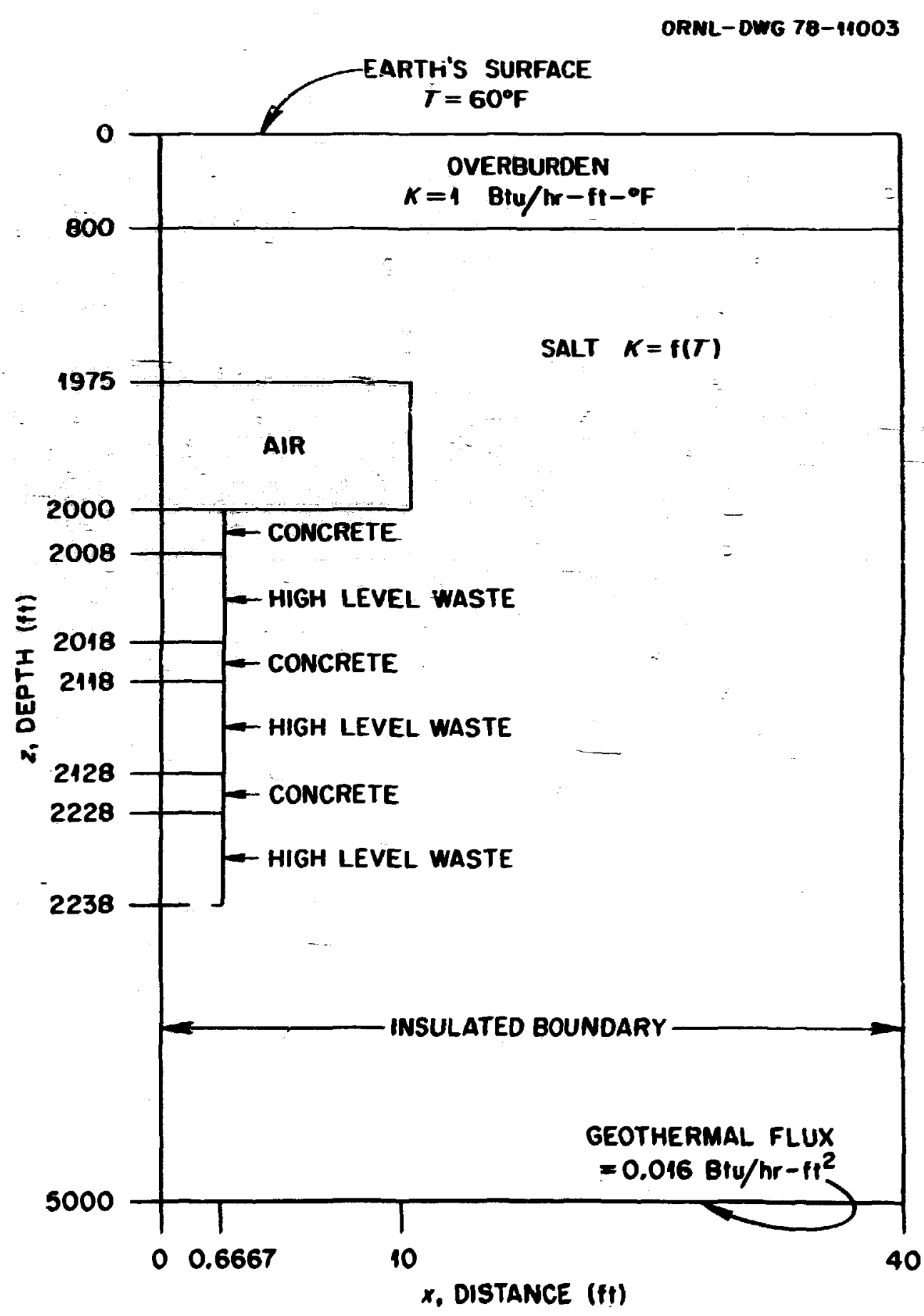

Fig. 14. Near-Field Multi-Level Thermal Model for Storage of High-Leve1 Waste in Salt. 
Table 3. Maximum average temperature increases predicted by the near-field models $a$

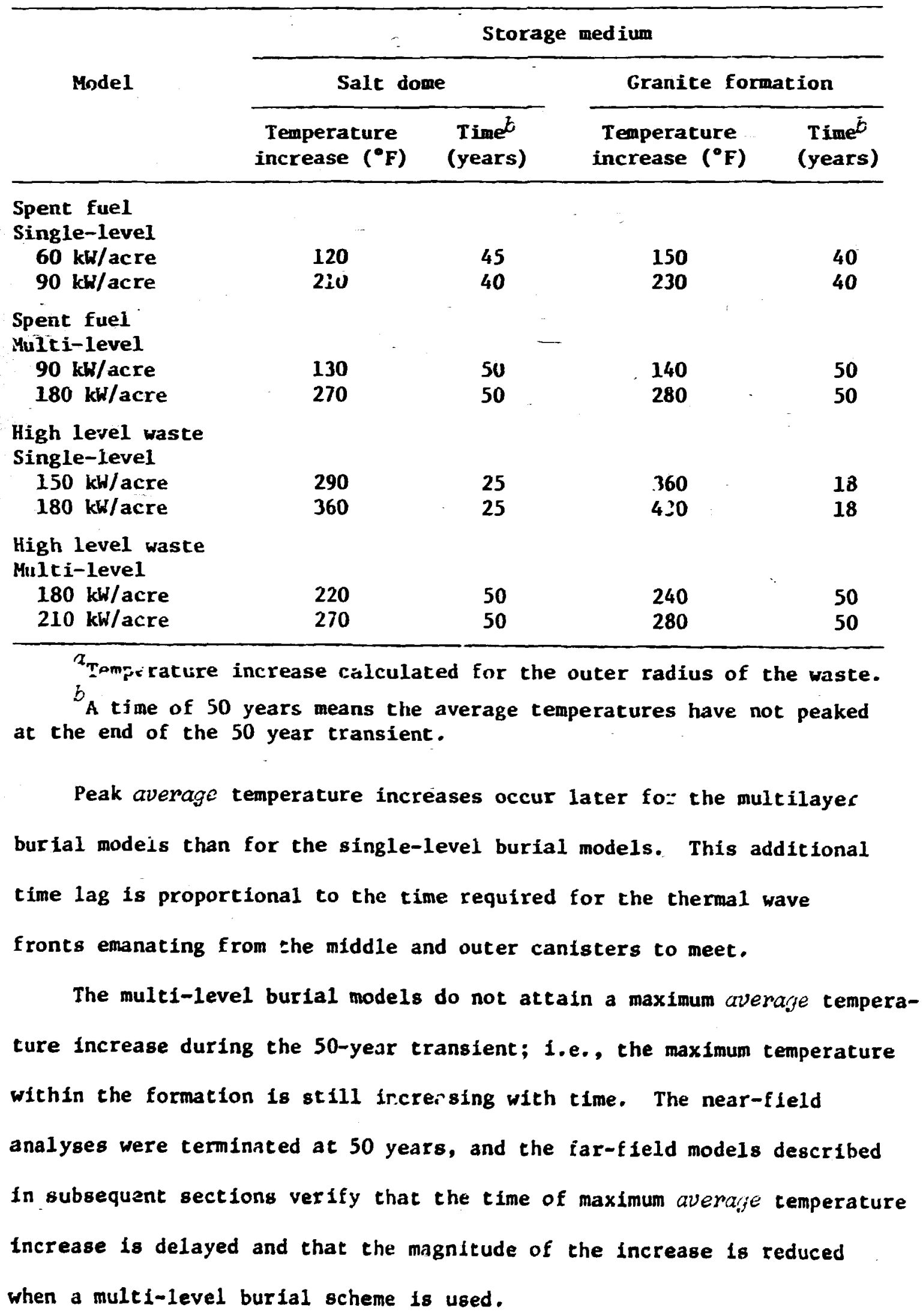




\section{FAR-FIELD MODELS}

Two-dimensional, cylindrical, far-field thermal models have been developed for comparison of the single- and multi-level repository concepts. Results of the car-field analyses are used co make qualitative comparisons of predicted temperatures and thermal uplifts between the different burial schemes. Because the primary purpose of the farfield analyses in this report is to predict the magnitude of the maximum thermal uplift, the transient calculations were terminated at 2500 years or the tine of maximum uplift, whichever is later.

Since the far-field analyses will cover time spans of thousands of years, the time in which the rooms are not backfilled (less than 50 years) is negligible when compared with the time in which they are backfilled. Therefore, the excavated areas in the repository arc assumed to be backfilled, with the backfill material having identica? properties of the surrounding geologic formation throughout the farfield analysis.

Heat generated by the radioactive decay of the waste was uniformly distributed in 2000-acre circular disks (5266 ft radius) and having properties of the surrounding medium. The waste is conservatively assumed to be loaded simultaneously throughout the repository. 3oth the radial and axtal boundaries of the models were chosen to extend to $15,000 \mathrm{ft}$. The $15,000 \mathrm{ft}$ boundirles were chosen so as to ensure isothernal boundaries throughout the transient analysis. Parametric studies utflizing one-dimensional models were used to determine the location of the fsothermal boundaries. Boundary conditions applied to 
th: far-field models, as described in Sect. 8, include a geothermal heat flux applied at a depth of $15,000 \mathrm{ft}$ and an isothermal boundary temperature of $60^{\circ} \mathrm{F}$ applied at ground level. Far-field models used in this sturly are sumwarized in Table 4.

Table 4. Summary of far-field models

\begin{tabular}{|c|c|c|c|c|c|c|c|c|}
\hline \multirow{2}{*}{$\begin{array}{l}\text { Type of } \\
\text { model }\end{array}$} & \multicolumn{4}{|c|}{ Spent fuel } & \multicolumn{4}{|c|}{ High-level waste } \\
\hline & 60 & kW/acre & 180 & kW/acre & 150 & $\mathrm{kH} / \mathrm{ac}=\mathrm{e}$ & 210 & $\mathrm{~kW} / \mathrm{acre}$ \\
\hline Single-level & & $x^{x}$ & & & & $\mathbf{x}$ & & \\
\hline Mulci-level & & & & $x$ & $\therefore$ & -.. & & $\mathbf{x}$ \\
\hline
\end{tabular}

\subsection{Single-Level Far-Field Models}

Far-field models representing the single-level schemes for the burial of HLW and SF in salt and granice formations are presented $i_{\text {is }}$ Figs. 15-18. The heat-genarating region representing the waste is modeled as a single homogeneous disk.

\subsection{Multi-Level Far-Field Motels}

Multi-level models, shown in Figs. 19-22, depict the burfal of three waste canisters in each vertical hole. Heat-generating regions representing the waste are modeled as three paralle 1 , homogeneous disks. 


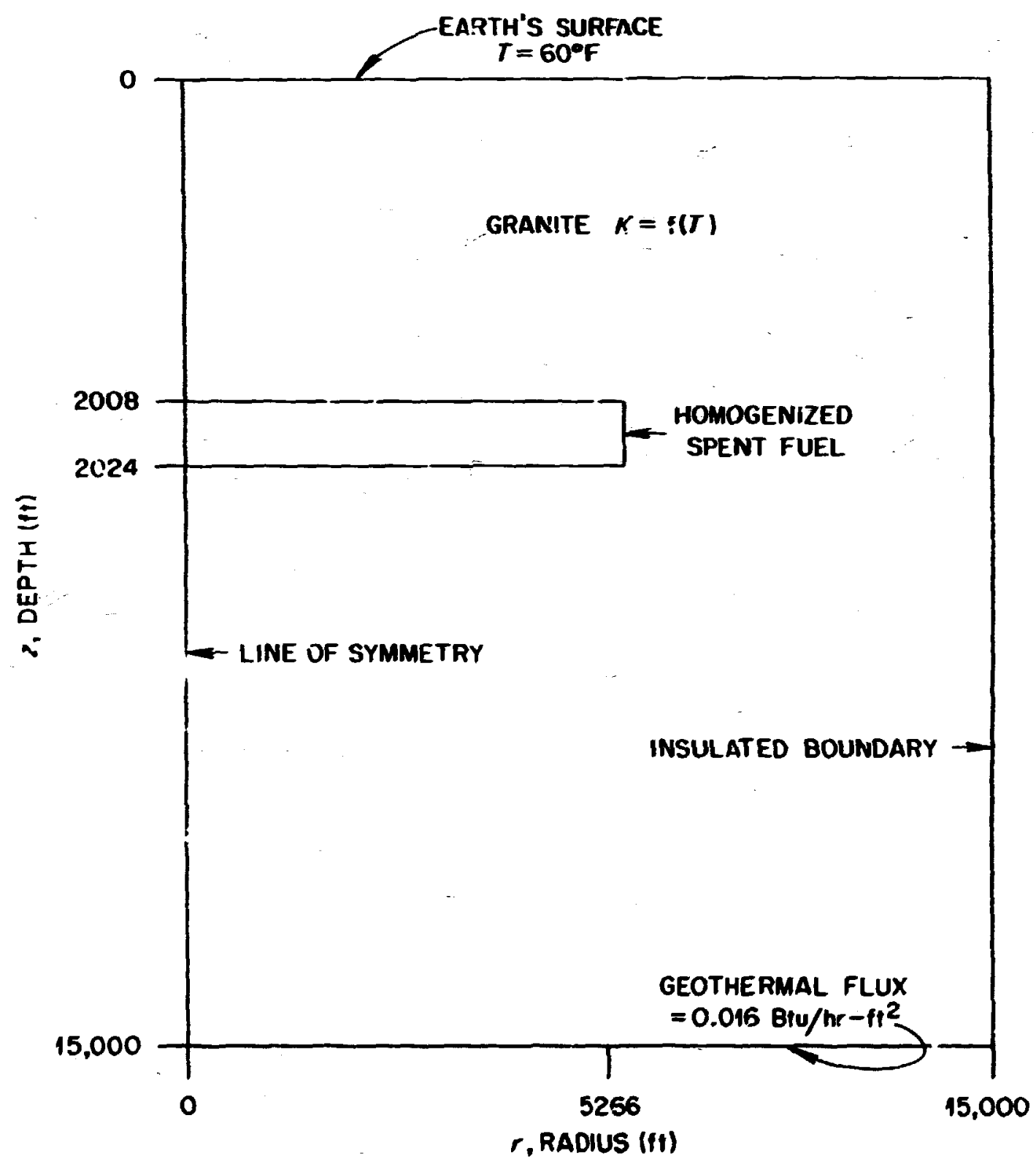

Fig. 15. Far-Field Single-Level Thermal Model for Storage of Spent Puel in Granite. 


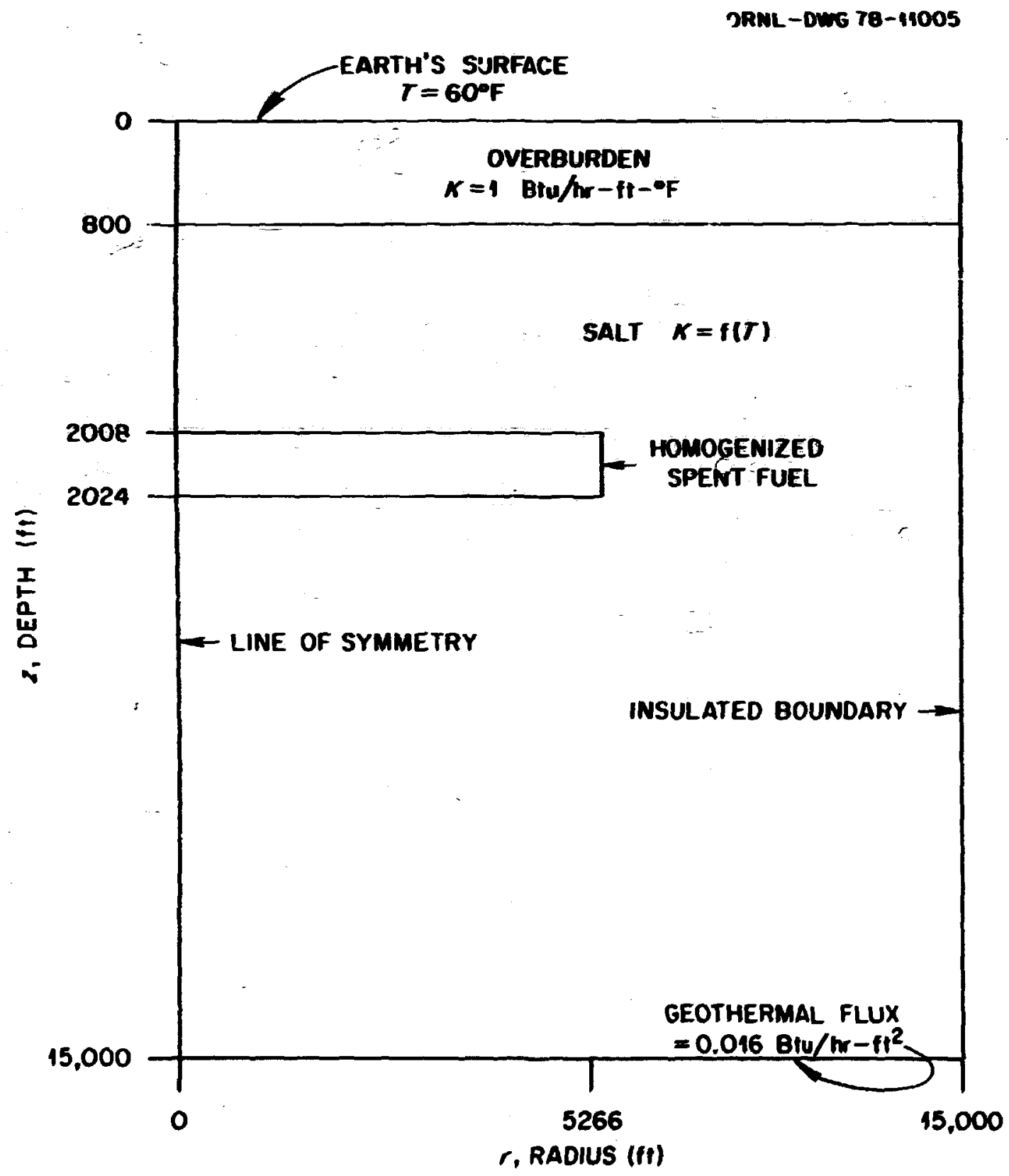

Fig. 16. Far-Field Single-Level Thermal Model for Storage of Spent Fuel in Salt. 


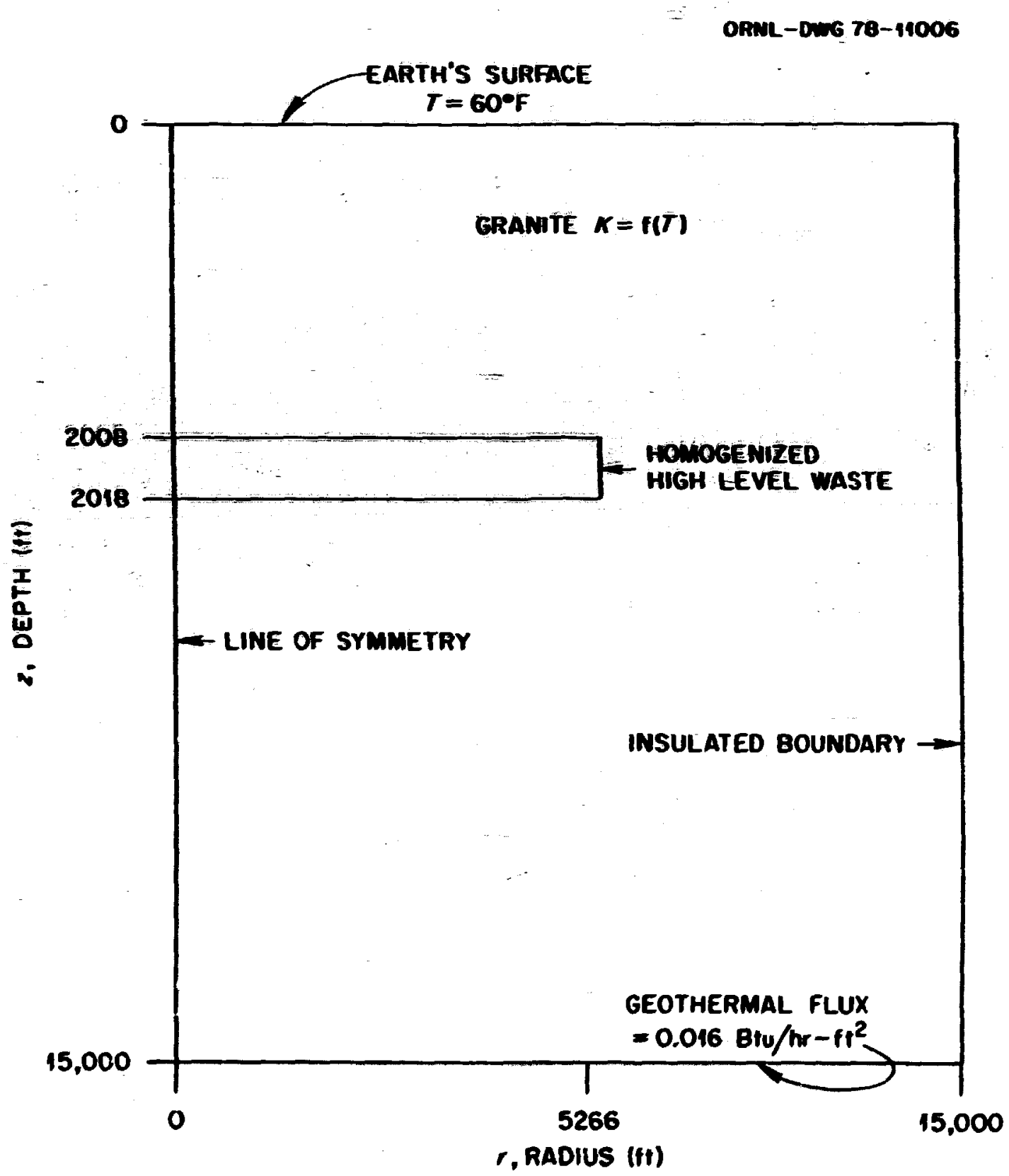

Fig. 17. Fir-Field Single-Level Thermal Model for Storage of High-level Waste in Granite. 
ORNL-DWG 78-41007

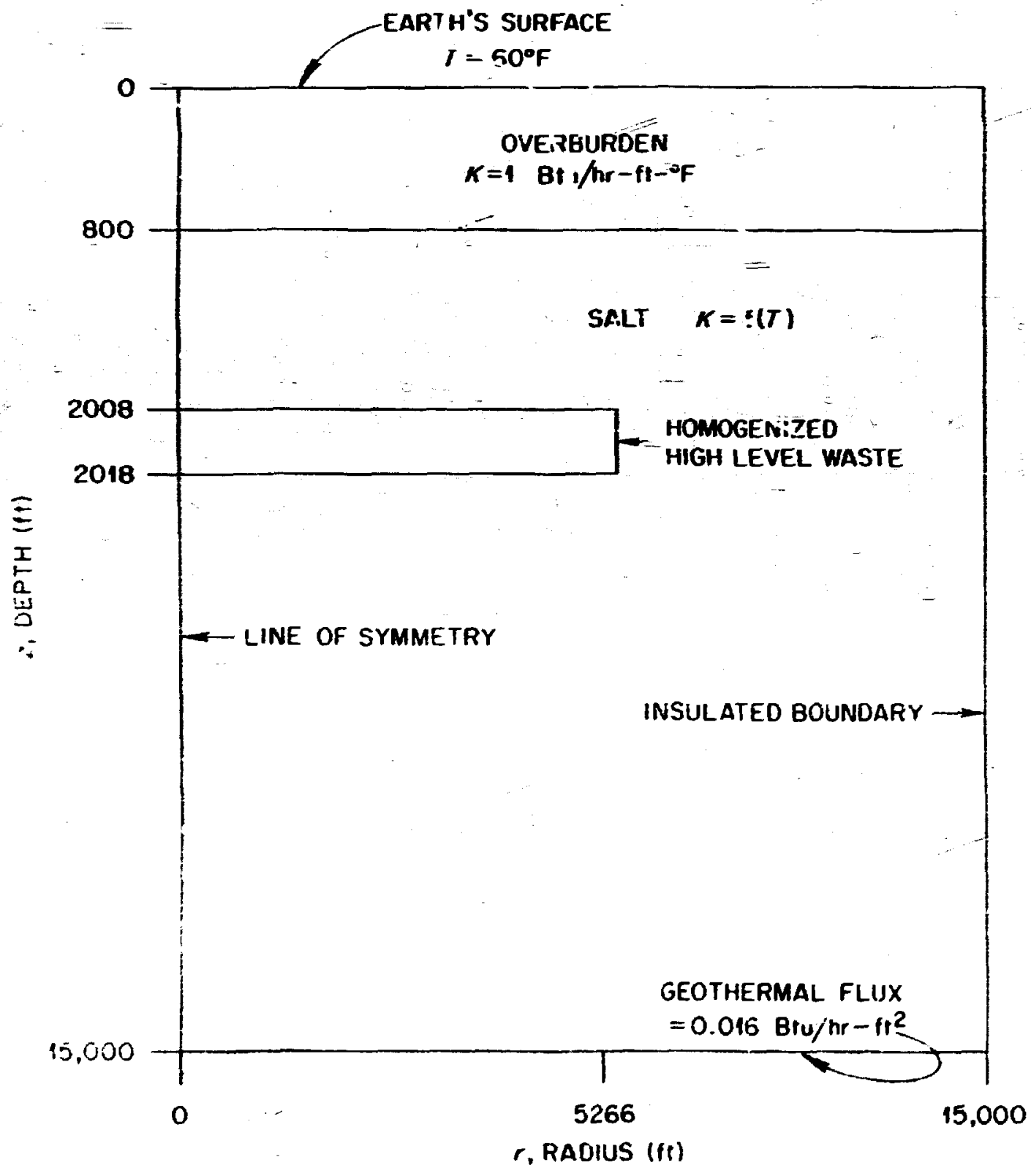

If: Id. Far-field single-ievel Thermal Model for storage of

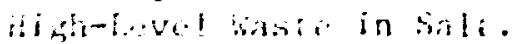




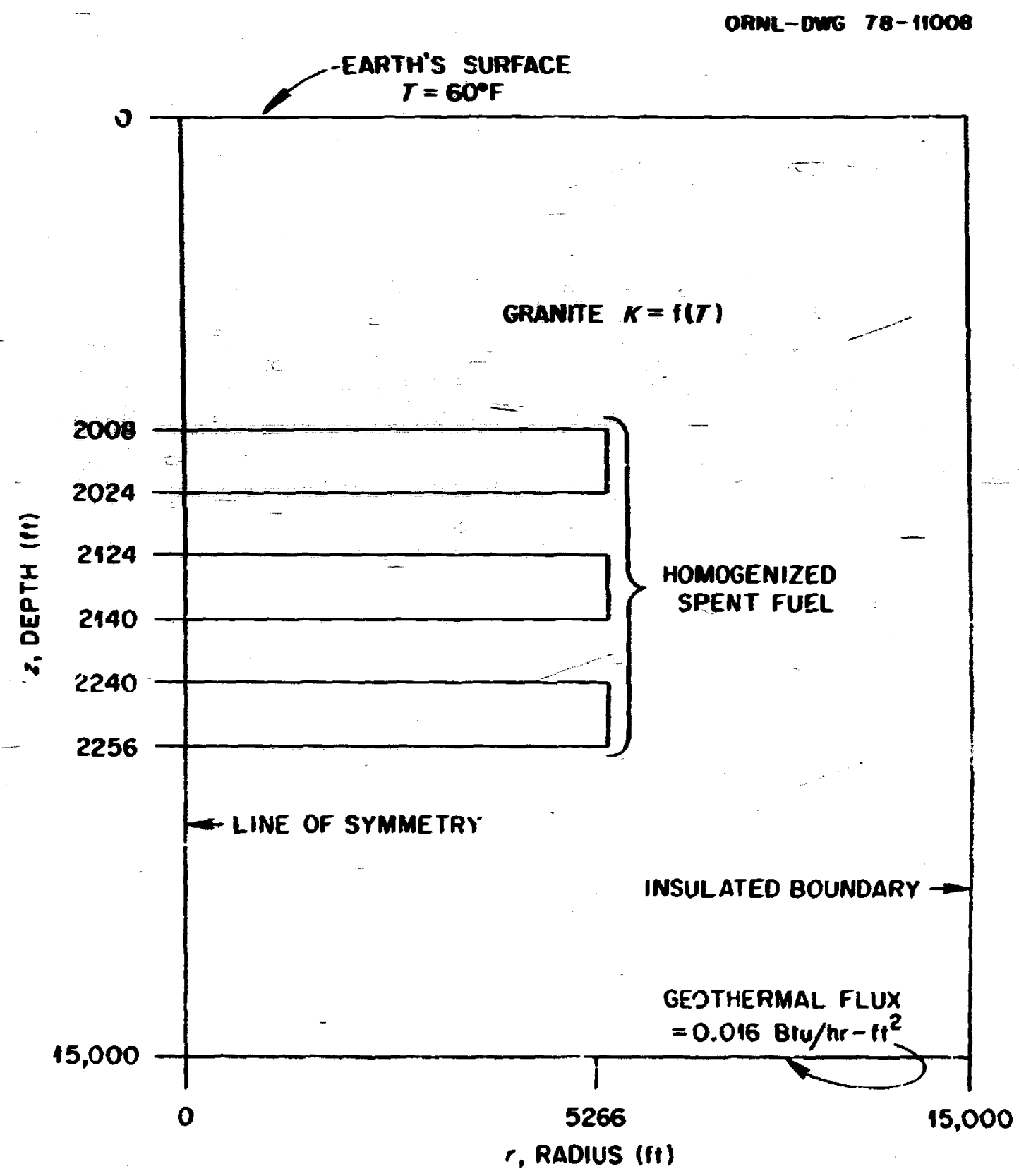

Pig. 19. Tar-Pield Multi-Level Thermal Model for Storage of Spent Fuel in Grantte. 


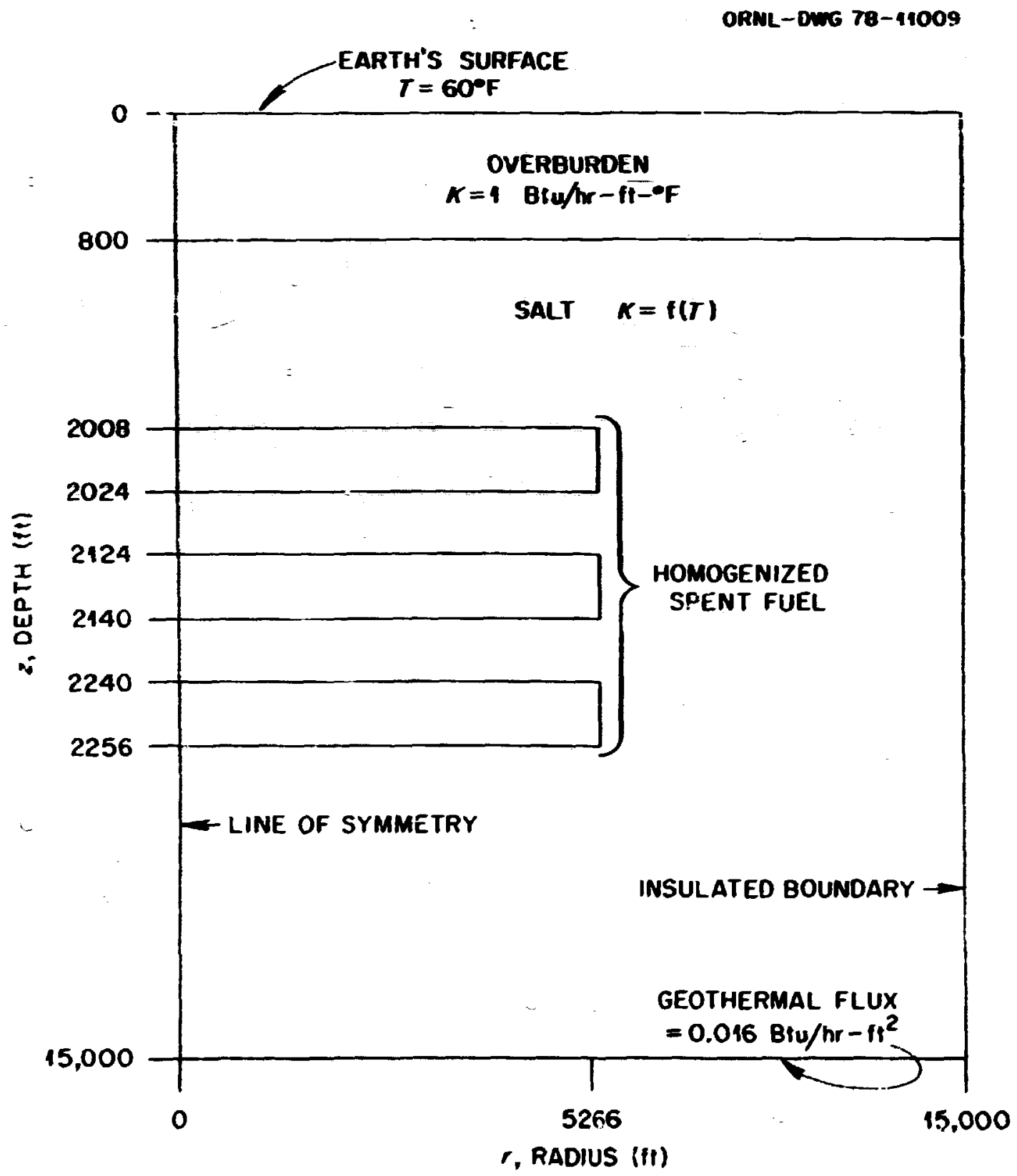

Fig. 20. Far-field Nilti-level Thermal Model for Storage of Spent Fiel in Salt. 


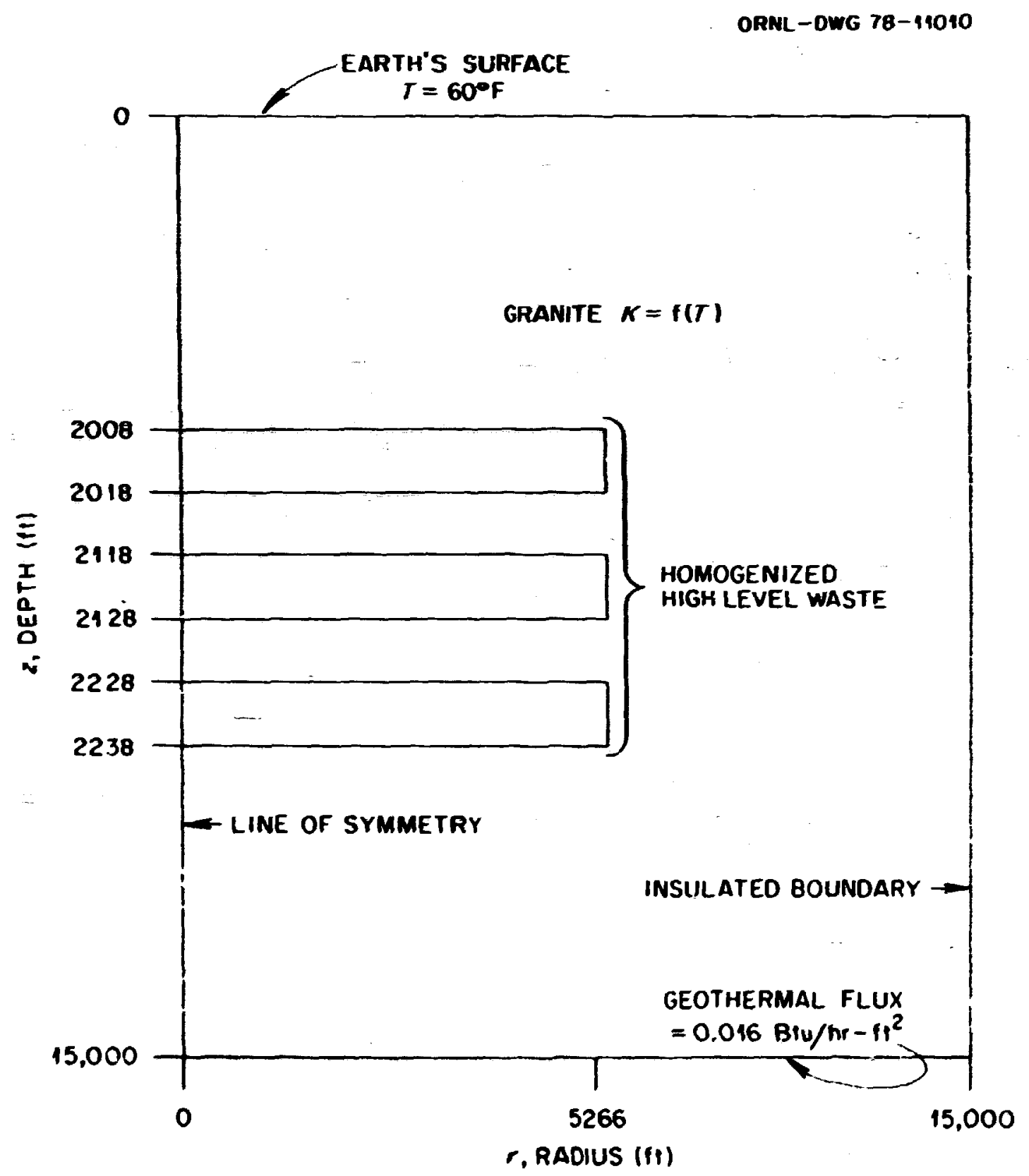

Fig. 21. Far-Field Multi-Level Thermal Model for Storage of High-level Waste in Granite. 


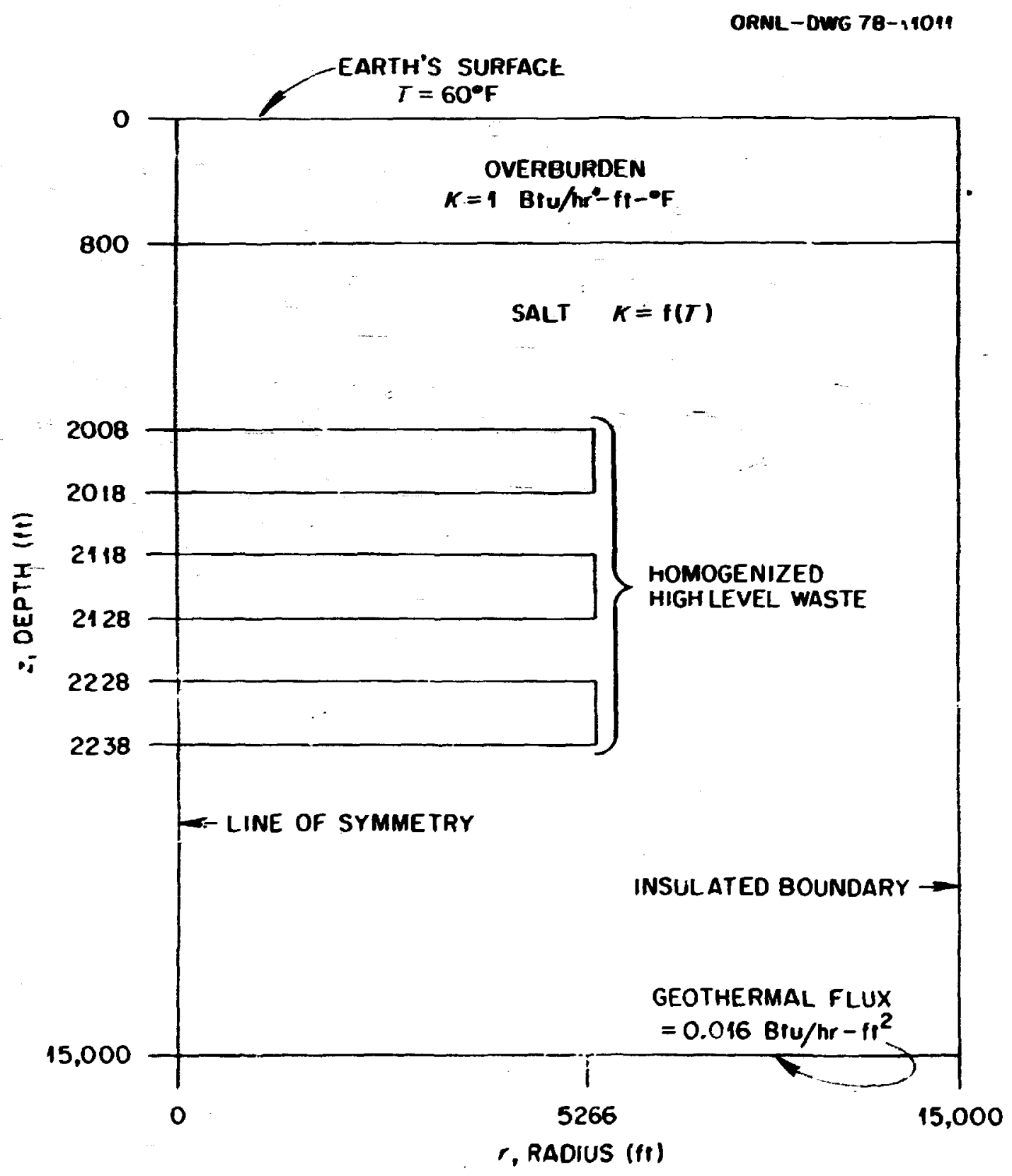

Fig. 22. Far-Field Multi-Level Thermal Model for Storage of High-level Waste in Salt. 


\subsection{Comparison of Maximum Average Temperature Increases}

The far-field models as $w \geq 11$ as the near-field models show that utilization of a multi-layer burial sche ge will result in a reduced peak average temperature increase. Homogenization of the heat-generating regions will result, of course, in lower ma::imum averaje temperatures that will occur ar a later time. These maximum average temperatures occur at the center of the repository at the midplane of the hea:generating region (or regions). A sumary of maximum average cemper ure, incr ses, prodicted by the far-field models is prosented in Table 5.

rable 5. Maxim:m average temperature increases calculated by the far-field mociels $s^{a}$

\begin{tabular}{l} 
Model \\
\cline { 2 - 4 } \\
$\begin{array}{l}\text { Temperature } \\
\text { increase }\left({ }^{\circ} \mathrm{F}\right)\end{array}$ (years)
\end{tabular}




\subsection{Comparison of Maximum Thermal Uplifts}

Thermal uplift in a repository is dependent on the repository material properties, the rate of energy supply to the formation, the total energy supplied to the formation, and the location of the energy source within the repository.

A simplified uplift model, as described in Sect. 3.2, was used to calculate the thermal uplift for each far-field calculation. Predicted uplifts are summarized in Table 6 and presented in graphical form in Figs, 23 and 24 .

Table 6. Sunmary of maximum thermal uplift

\begin{tabular}{|c|c|c|c|c|}
\hline \multirow{3}{*}{ Model } & \multicolumn{4}{|c|}{ Storage medium } \\
\hline & \multicolumn{2}{|c|}{ Salt dome } & \multicolumn{2}{|c|}{ Granite formation } \\
\hline & $\begin{array}{l}\text { Uplifta } \\
(f t)\end{array}$ & $\begin{array}{c}\text { Time } \\
\text { (years) }\end{array}$ & $\begin{array}{l}\text { Uplift } \\
\text { (ft) }\end{array}$ & $\begin{array}{l}\text { Time } \\
\text { (years) }\end{array}$ \\
\hline $\begin{array}{l}\text { Spent fuel } \\
60 \mathrm{~kW} / \text { acre single-level } \\
180 \mathrm{~kW} / \text { acre multi-level }\end{array}$ & $\begin{array}{l}12 \\
36\end{array}$ & $\begin{array}{l}3500 \\
4000\end{array}$ & $\begin{array}{l}1.2 \\
3.9\end{array}$ & $\begin{array}{l}7000 \\
7500\end{array}$ \\
\hline High-level waste & & & & - \\
\hline $\begin{array}{l}150 \mathrm{~kW} / \text { acre single-level } \\
210 \mathrm{~kW} / \text { acre multi-level }\end{array}$ & $\begin{array}{r}8 \\
11\end{array}$ & $\begin{array}{l}700 \\
800\end{array}$ & $\begin{array}{l}0.79 \\
1.1\end{array}$ & $\begin{array}{l}1000 \\
1250\end{array}$ \\
\hline \multicolumn{5}{|c|}{$\begin{array}{l}a_{\text {The predicted magnitudes of thermal uplift are highly conservative }} \\
\text { upper limits, and they should be used for qualitative comparison only. } \\
b \text { The predicted times of peak thermal uplift were taken at the } \\
\text { print-out time at which the peak uplift occurred. As a finite number of } \\
\text { print-out times were used, the times of peak uplift should be considered } \\
\text { as estimates, and they should be used for qualitasive comparisons only. }\end{array}$} \\
\hline
\end{tabular}

Examination of the maximum uplifts tabulated in Table 6 indicates that the thermal uplift is roughly proportional to the energy supplied to the formation. For example, increasing the "real. loading from 


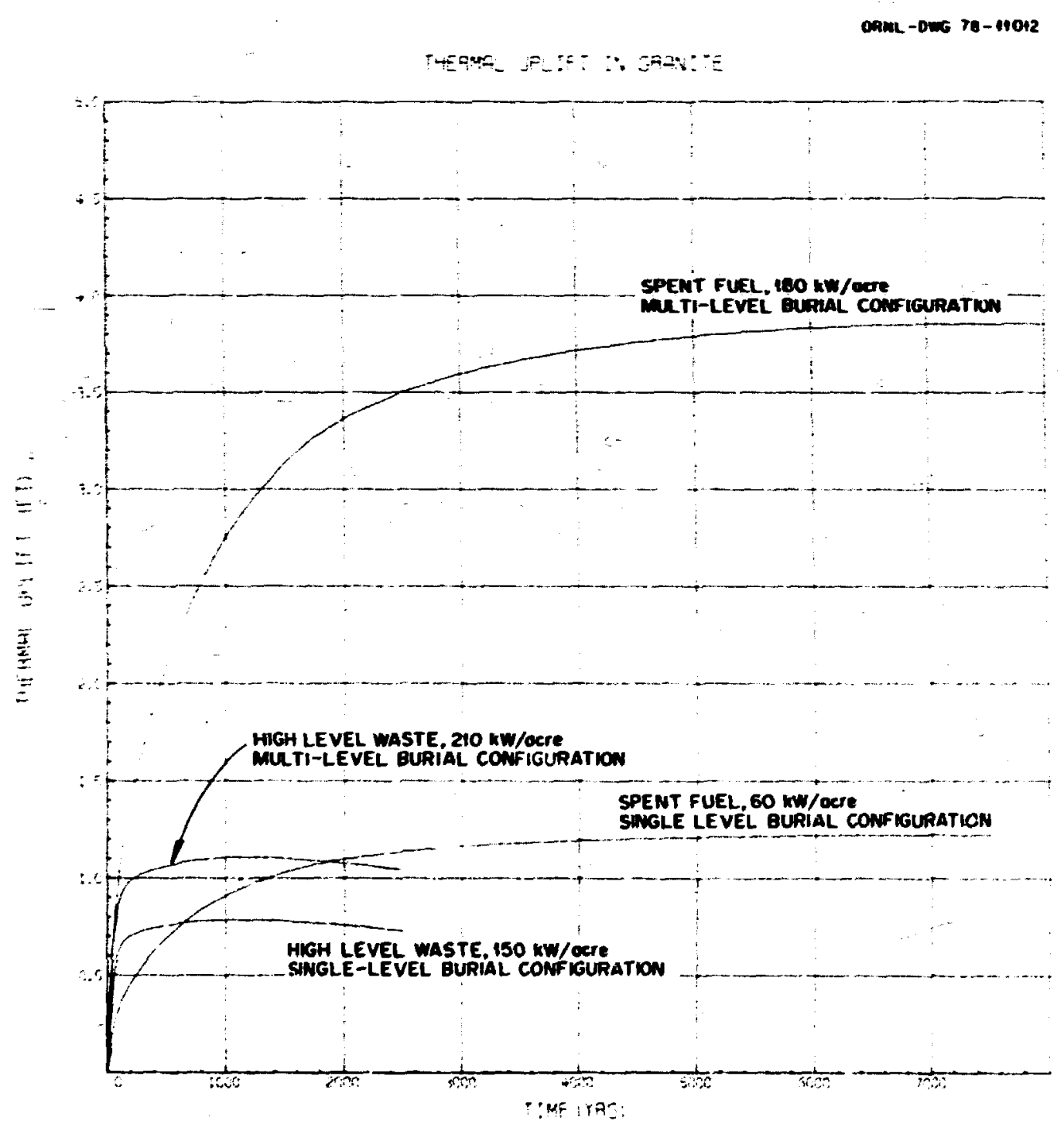

Ffg. 23. Thermal Uplift in Granite. 


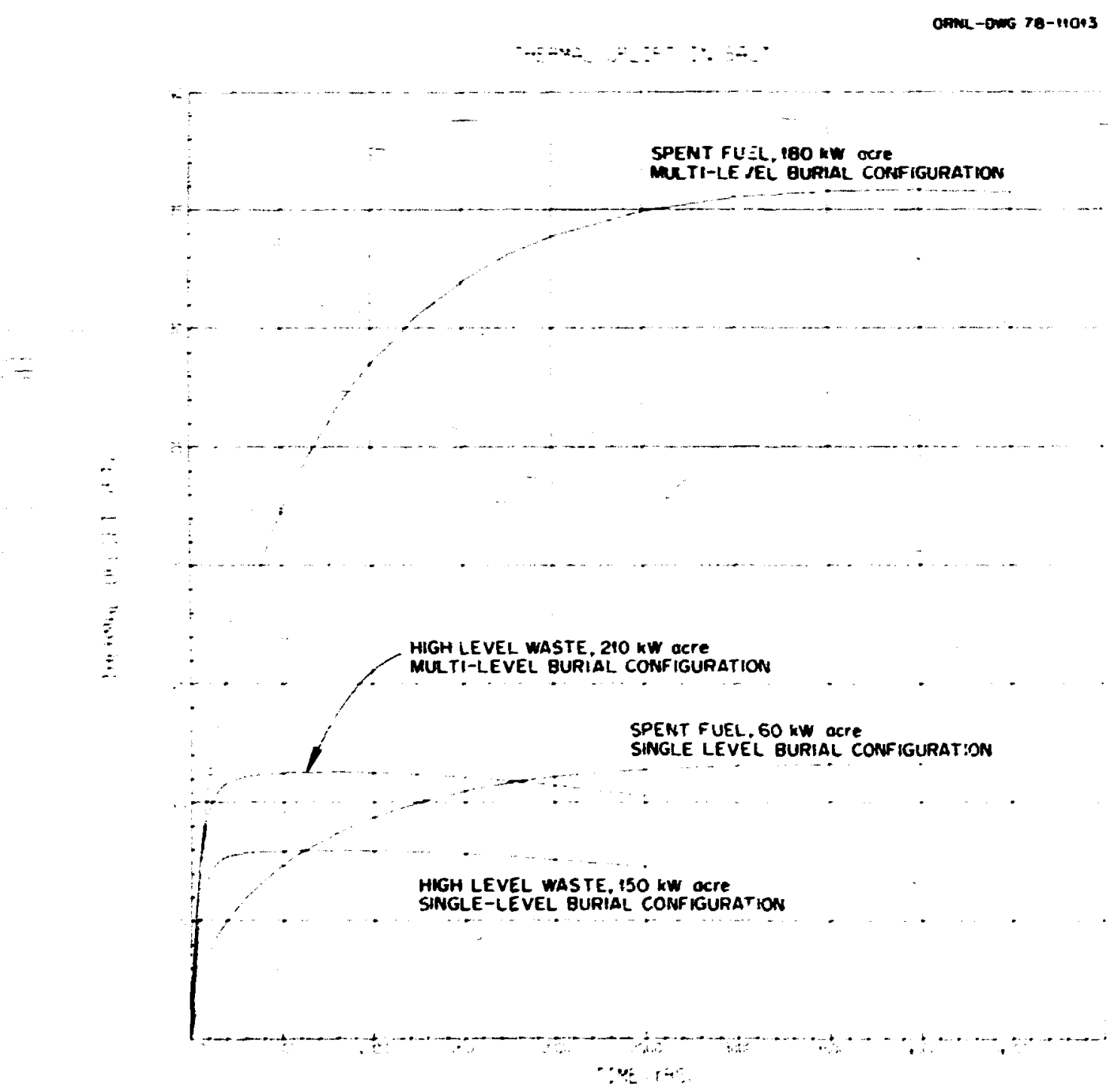

Fig. 24. Thermal Uplift in Salt. 
$60 \mathrm{~kW} /$ acre to $180 \mathrm{~kW} /$ acre results in the peak uplift increasing by a factor of 3.3 for the burial of spent fuel in granite and of 3.1 in salt formations.

The uplift curves shown in Figs. 23 and 24 are relatively flat, and the maximum uplift is "maintained" over a span of hundreds of years. For example, for spent fuel loaded in a granite formation at $60 \mathrm{kw} / \mathrm{acre}$, the uplift does not peak until 7000 years. However, the peak, uplift is essentially reached after only 3000 years.

The predicted time at which the peak thermal uplift occurs varies from 700 to 7500 years, dependfing on both the burial configuration and the areal thermal loadings. Other studies have indicated that the time of maximum thermal uplift will occur substantially earlier. For example, high-level waste buried in a salt formation with an areal loading of $150 \mathrm{~kW}$ per acre, is predicted by Lincoln, Larson, and Sisson ${ }^{7}$ to reach a peak thermal uplift af-ter only 150 years, unlike the present study, which predicts that it will peak after 700 years. This discrepancy is st11l unresolved and will be the subject of future investigations. 


\section{Comparison of thermal Profiles}

Temperatures predicted throughout the transient analyses we:e generated as output from HEATINGS in the form of tabular data, and output from the near-field analysis was converted by $\approx$ post processor, HEATPLOT, ${ }^{8}$ into contour plots that depict lines of constant temperature increase. Examination of these contour plots yields additional insight into the thermal effects of the different repository concepts.

Representative contour plots of the near-field results at 1,5 , and 50 years after burial o. the waste in salt and granite formations are presented in Appendices $A$ and $B$, respectively.

\subsection{Single and Multi-Level Repositories}

It is of interest to examine and compare the temperature profiles predicted for the single-level and multi-level repository models in which the repository material, areal loading, and type of waste are identical.

There are two main thermal effects in cianging from a single-level to a multi-level repository. First, both thermal gradients and may.mum temperature increases are significantly reduced by dispersion of the waste in a multi-layer repository. Therefore; maximum thermal stresses are reduced. The maximum temperature increase in the multi-level repository considered in this study will occur at the midpiane of the middle canister of waste. For the assumed decay curves of HI.W and SF, the time of maximum temperature increase will occur after the thermal wave fronts emanating from the upper and lower canisters reach the 
middle canister. The additional time required for the wave fronts to reach the middle canister is the primary reasun that the time of maximum temperature increase occurs later in a multi-level repository than in a single-layer repository.

\subsection{Ef fect of the Repository Material Properties}

Comparisons of the results presented in Appendices $A$ and $B$ indicate that changing the repository material (i.e., thermal properties) has an appreciable effect on the results. Salt, which has a higher thermal conductivity than granite, will allow energy generated by the waste to diffuse faster. This increased heat diffusion accounts for lover temperature increases and therwal gradients being predicted for a salt repository. That the thermal expansion coefficient of salt is approximately five times larger than that of granite accounts for the much higher thermal uplift in a salt formation. 


\section{CONCLUSTONS AND RECOMMENDATIONS}

A scoping study has been completed to determine the effects of a multi-level, terminal repository design for tha storage of either high-level waste or spent fuel. Near-field calculations have been made in both salt and granite formations to estimate the ceuperature profile in the region close to the waste. Far-field calculations were also made so that qualitative comparisons of peak thermal uplifts could be made, for the same initial areal thermal ioading.

Results of this study indicate that thanging from a single- to a muit:-layer repository design yields decreased thermal gradients and cemperalutis increases. However, the peak thermal up Ift is increased by using a multi-iayer repository design for the same loading cenditione.

There are two primary reasons for the increased thermal uplift in a multi-layer repository. First, the axial dispersion of heat results in a larger amount of material being heated. Because the thermal conductivity of salt and granite decrease with temperature, and because of the existence of a geothermal gradient, the effect of moving the heat generating region downuard is to decrease the thermal conductivity of the surrounding medium. This reduced conductivity retards the dispersial of heat, which results in increased maximum temperatures and thermal uplifts.

Changing the repository material (i.e., thermal propertes) was found to have an appreciable effect on the results. The higher thermal conductivity of salt, as compared to that of granite, resulted in lower crmperature increases and thermal gradients being predicted for a salt repository. The higher thermal expansion coefficfent of salt also resulted in a much larger thermal uplift in a salt formation. 
The maxim thernal uplift in a repository is dependent on the waste material, areal loadiug, repository material, and the type of storage configiration used. At constant areal loading, as the nuber of-aste caniscers in a vertical hole is increased; two opposing effects occur: tive heat generating region is increased in the vertical direction, which tends to increase the maxim thermal uplift; iowever, the heat source becomes wore dispersed (with an increased heat transfer azea), which tends to decrease the maximan thermal uplift. Therefore, because of the many interacting factors that influence the maximum thermal uplift in a repository, the uplift results calculated as part of this study should not be extrapolated to other types of multi-level repository concepts.

Increased accuracy can be obtained by using the actual repository stratigraphy of a proposed site to formulate the thermal model. Furthermore, the thermophysical properties of the repository material should be measured and used in the analysis, since they are a key factor in the modeling accuracy.

After the model has been refined co reflect an actual rather than a hypothetical repository, both near- and far-field analyses should be repeated. If a multi-level repository still appears to be a feasible alternative, a detailed three-dimensional near-field model should be developed to estimate the temperature profile better in the regiun close to the waste canisters. This model should also be formulated so that the effects of air circulation and room cooling are considered. 


\section{REFEREICES}

1. D. W. Turner, D. C. Elrod, and I. I. Sinan-Tov, EEATIMG5 - An IBR' 360 Heat Conduction Drogran, Oak Ridge National laboratory, ORNW/CSD/TH-15 (March 1977).

2. Oral commication with J. E. Russell.

3. Internal correspondence from D. W. Turner to $W$. A. Burnett, August 1977.

4. M. J. Bell, ORIGEV: The ORNL Isotope Generation and Depletion Code, Oak Ridge National Laboratory, USAEC Report ORML-4628 (May 1973).

5. G. D. Smith et al., "Soil-Temperature Regimes, Their Characteristics and Predictability," USDA Soll Conservation Service, SCS-Tp-144 (April 1964).

6. B. Gutenberg, Physics of the Earth's Interior, Academic Press, New York, 1959.

7. R. C. Lincoln, D. W. Larson, and C. E. Sisson, Estimatea of Relative Amas for Limpoal in Bedded salt of LWR Wastes from ALtemate Fue Z Yclea, Sandia Laboratories, SAND 77-1816, January 1978. 
B. D. C. Elrod and D. W. Turner, HEATDSOT - I Temperature Dístrioution Plotting Program for SEATING5, Oak Ridge Gaseous Diffusion Plant, K/CSD/TA-11 (July 1977). 
Appendix A

THERMAL CONTOUR PLOTS FOR HASTE BURIAL IN SALT 


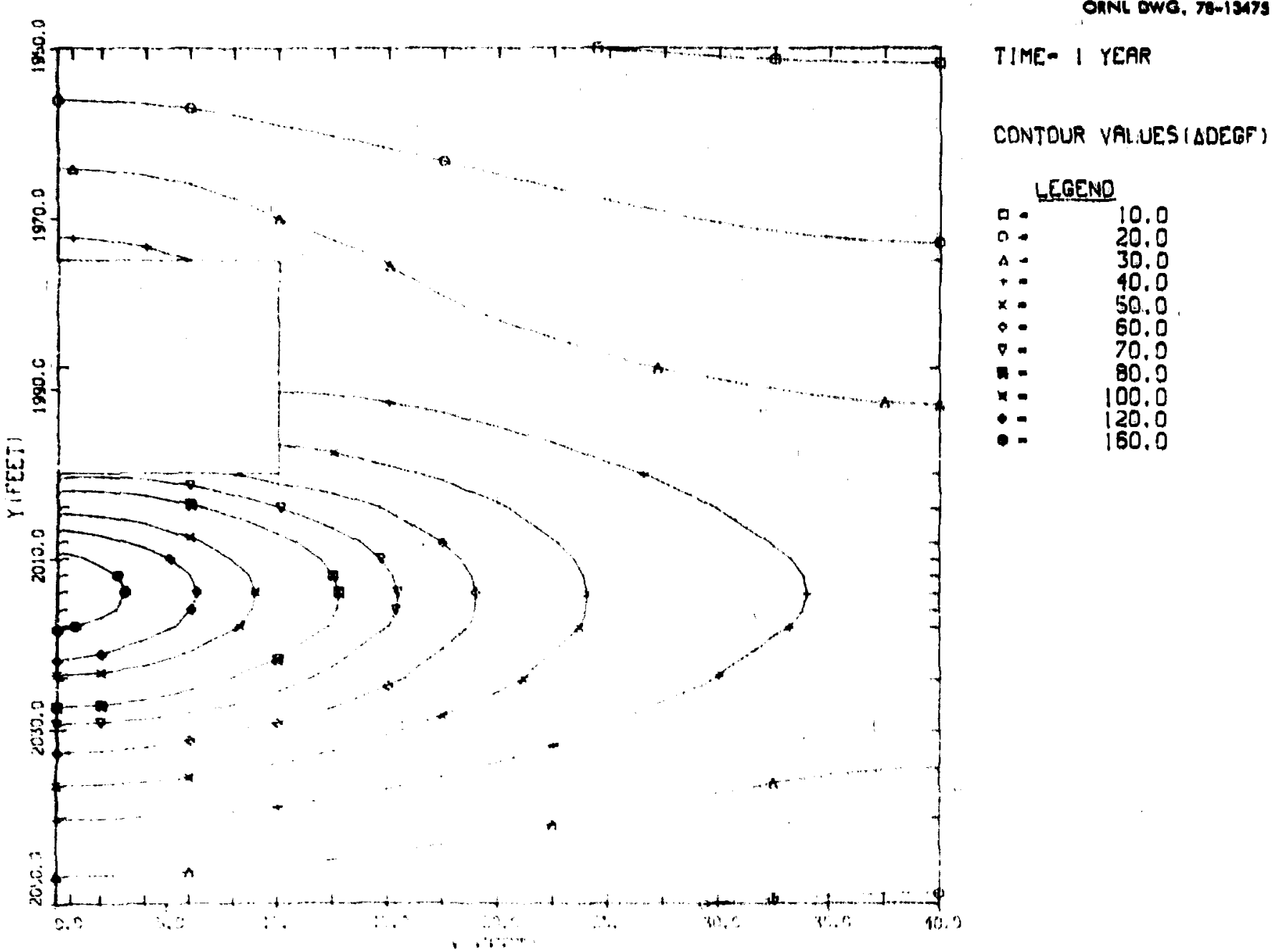

Fig. 25. Isothermal Plct at 1 Year for High-Level Waate Burled in Salt at an Areal loading of $180 \mathrm{~kW}$ per Acro Uaing a Single-Level Burial Configuration. 
ORNL DWO, 78-13476

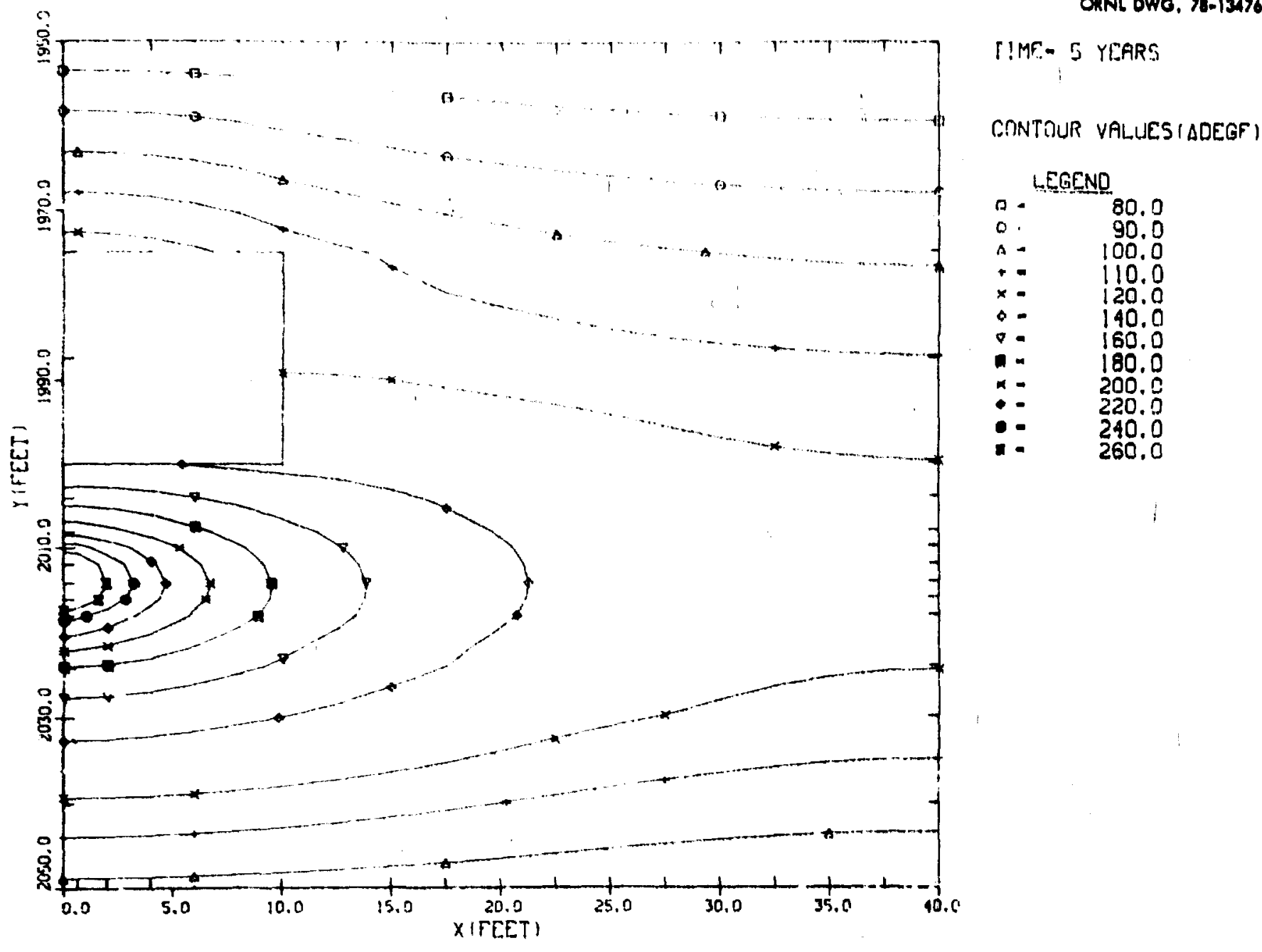

Fig. 20. Isothermal Plot at 5 Years for High-Level Waste Burled in Salt at an Areal Loading of $180 \mathrm{~kW}$ yer Acre Using a Single-Level Burial Configur con. 


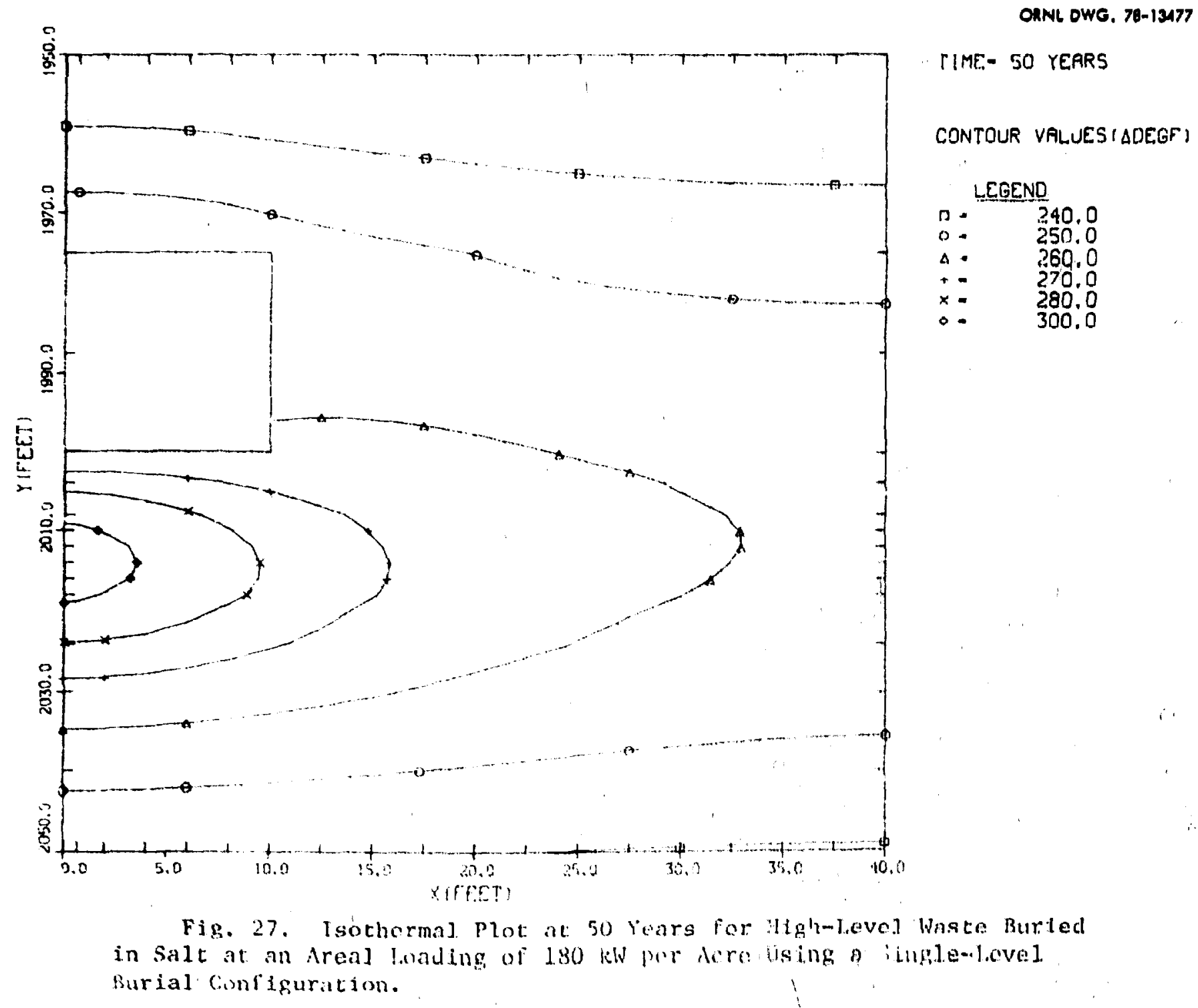


ORNL DWO, 78-13478

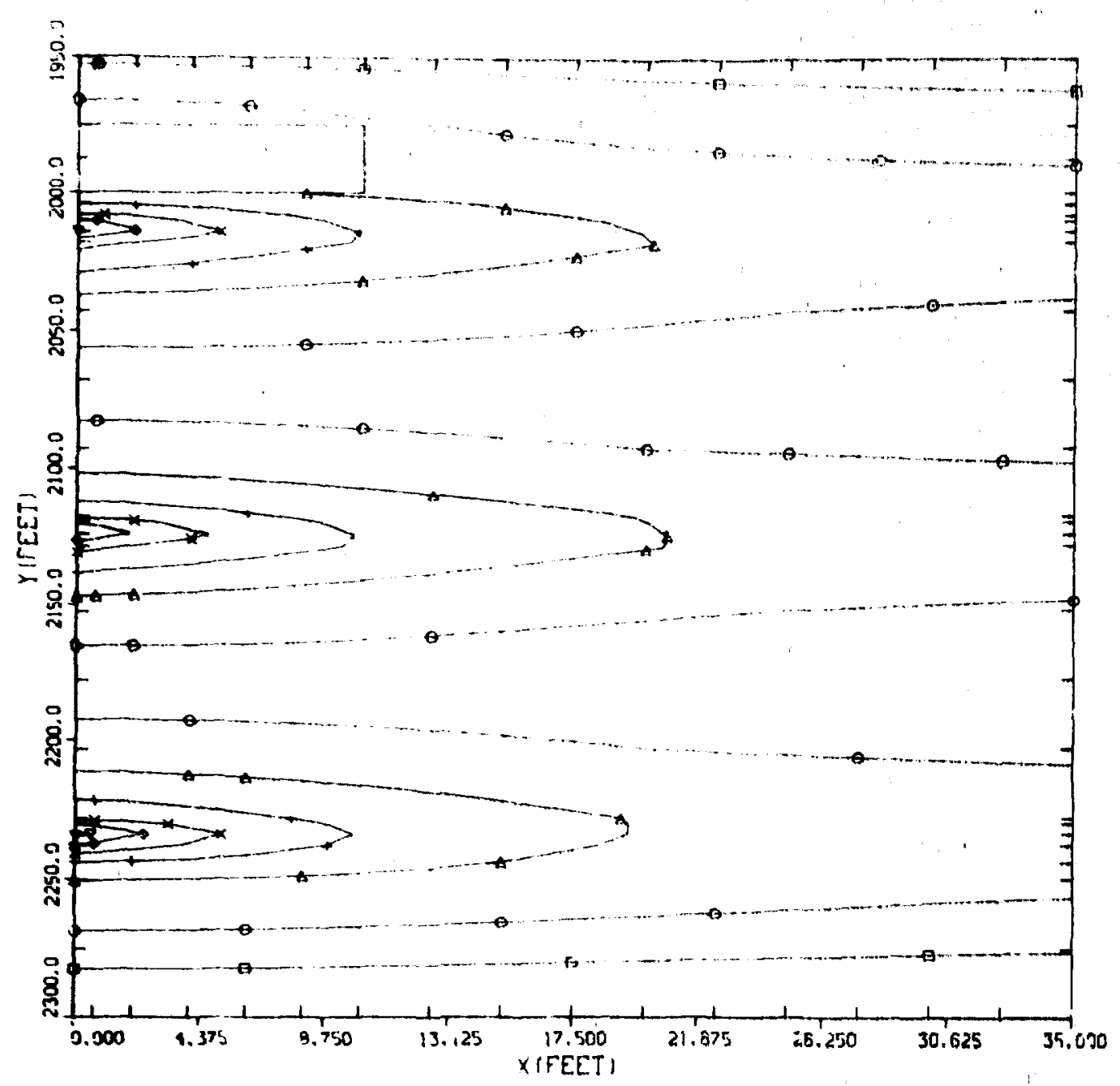

TIME- I YEAR

CONTDUR VALUESIADEGF)

LEGEND

5.5 .0

0.10 .0

$A=20.0$

$\therefore \quad 30.0$

$x=40.0$

$\begin{array}{ll}-: & 50.0 \\ & 60.0\end{array}$

Fig. 28. Isothermal Plot at 1 Year for High-Level Waste Burled in Salt at un Areal Loading of $180 \mathrm{~kW}$ per Acre Using a Mult1-Level Burlal Conf iguration. 
ORNL DWa, 7e-1349

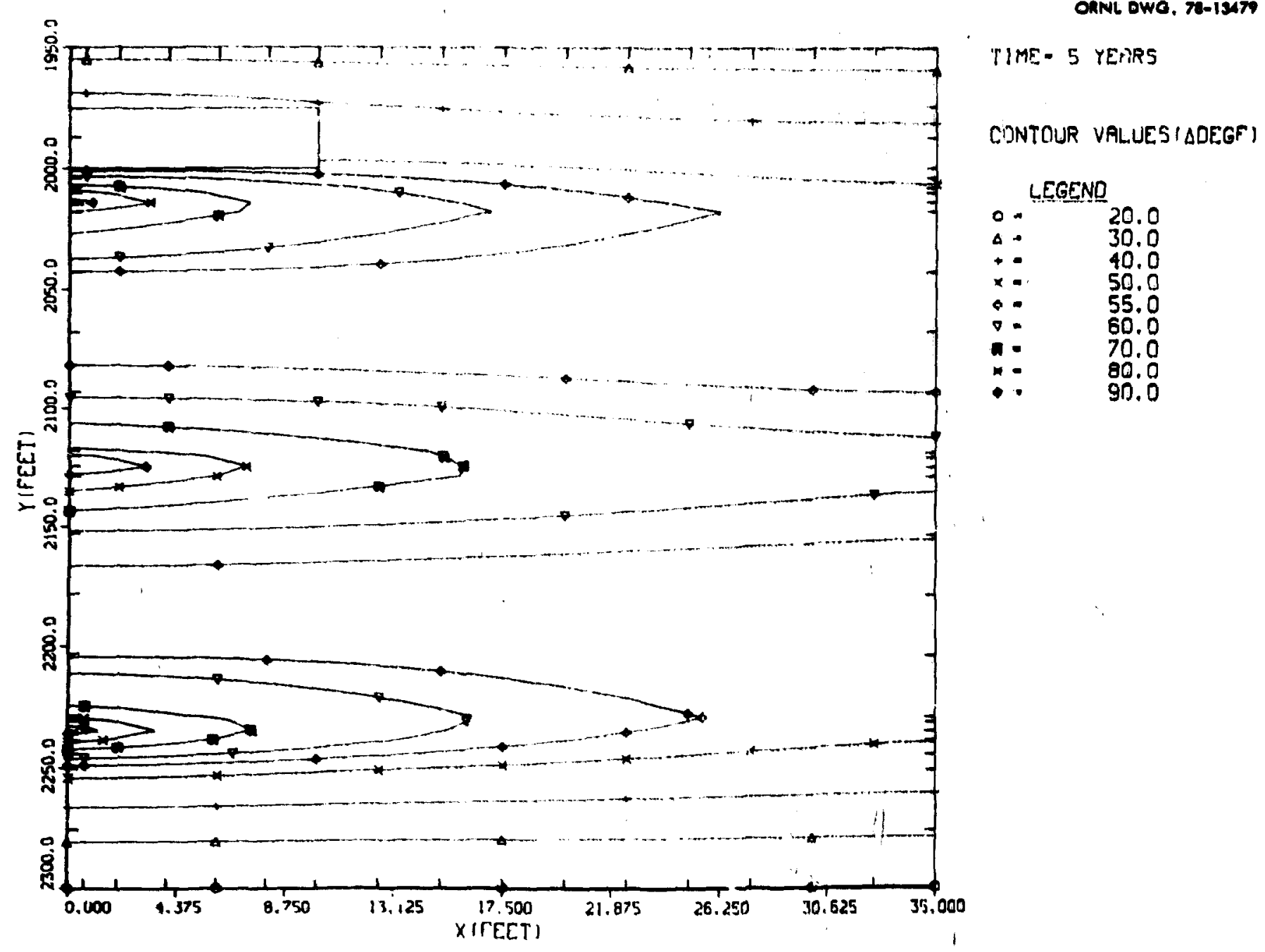

Fig. 29. Isothermal Plot at 5 Years for High-Level Waste Burled in Salt at an Areal Loading of $180 \mathrm{~kW}$ per Acre Using a Mult1-Level jurial Configuration. 


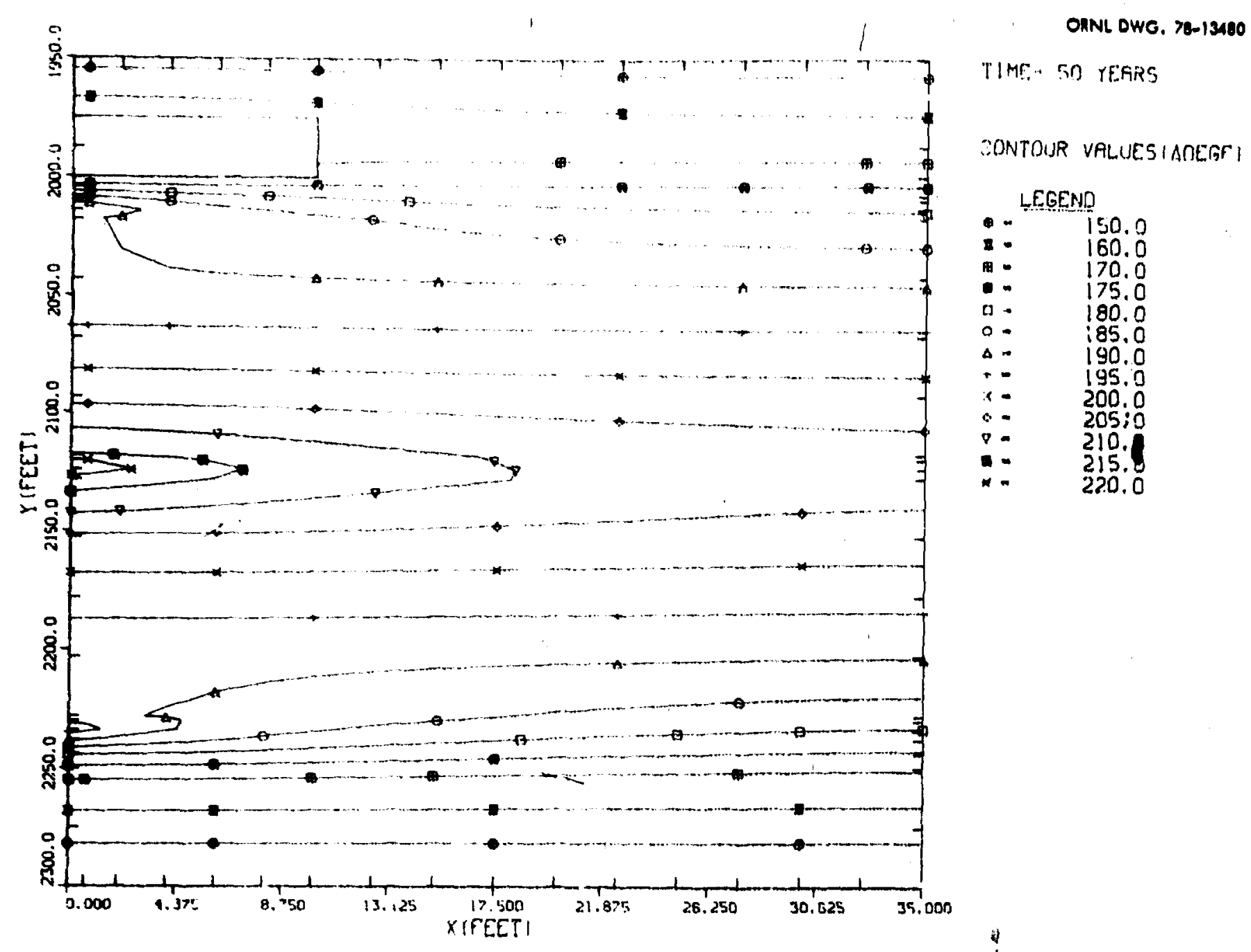

Fig. 30, Isothermal Plot at 50 Years for High-Level Waste Burlad in Salt at an Areal Loading of $180 \mathrm{~kW}$ per Acre Using a Multi-Level furfal Configuration. 


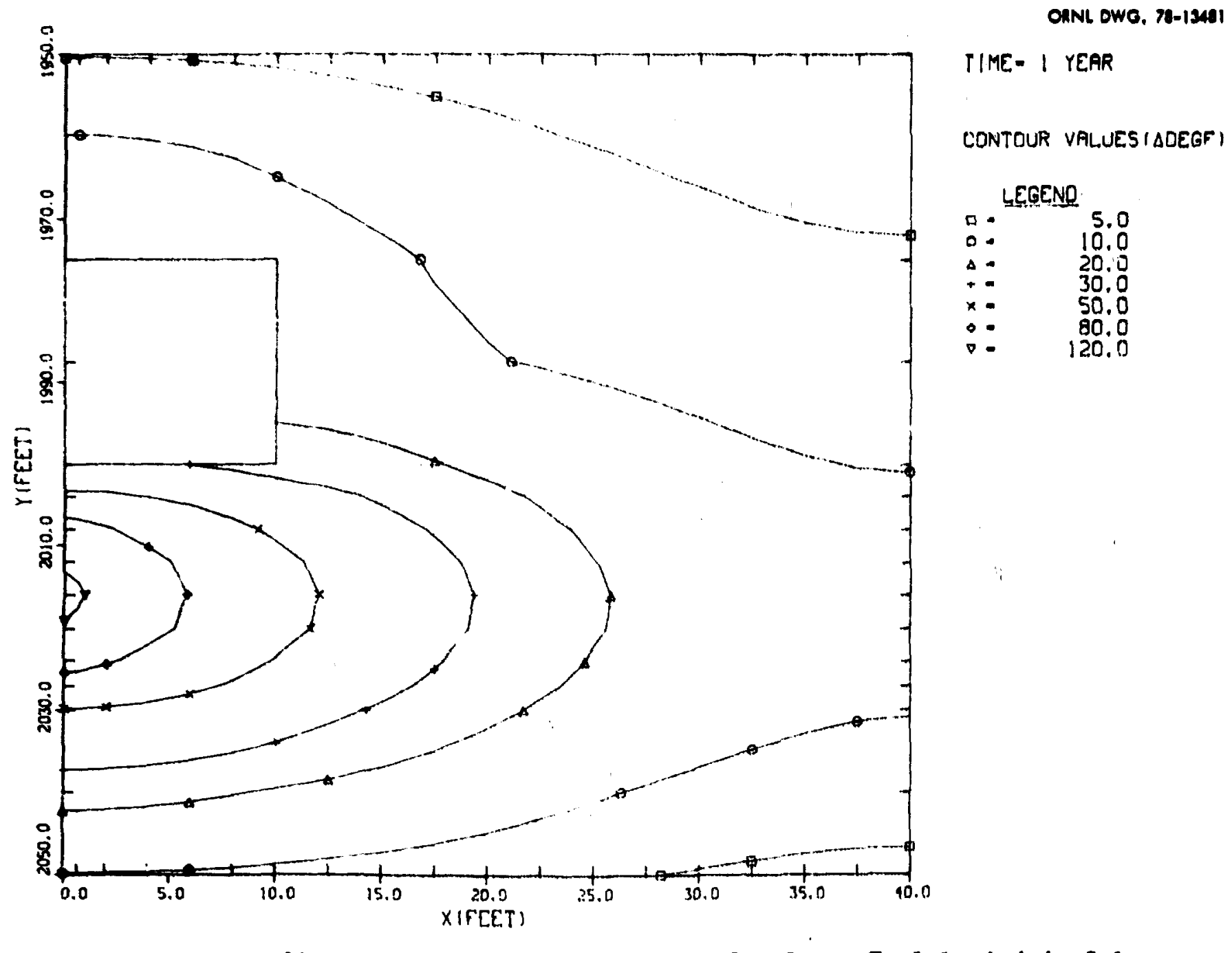

F1g. 31. Isotharmal Plot at 1 Year for Spent Fuel burled In Salt at an Areal Loading of $90 \mathrm{~kW}$ per Acre Using a Single-tevel Burlal Conf iguration. 
ORNL OWO. 70-13488

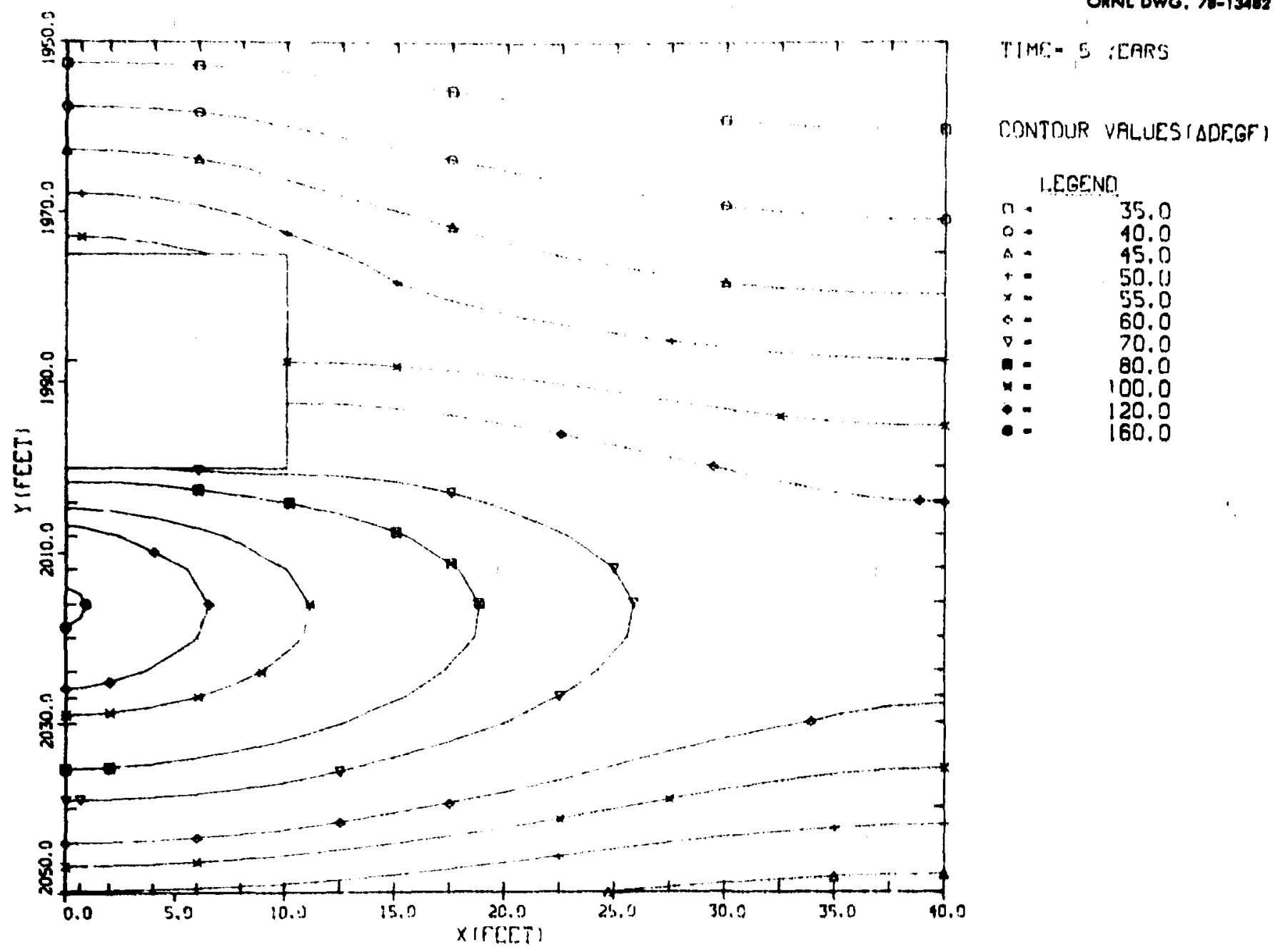

Fig. 32. Isothermal Plot at 5 Years for spent Fuel Buried in Salt at an Areal loading of $90 \mathrm{~kW}$ per Acre Using a Single-level Burla1 Conf iguration. 


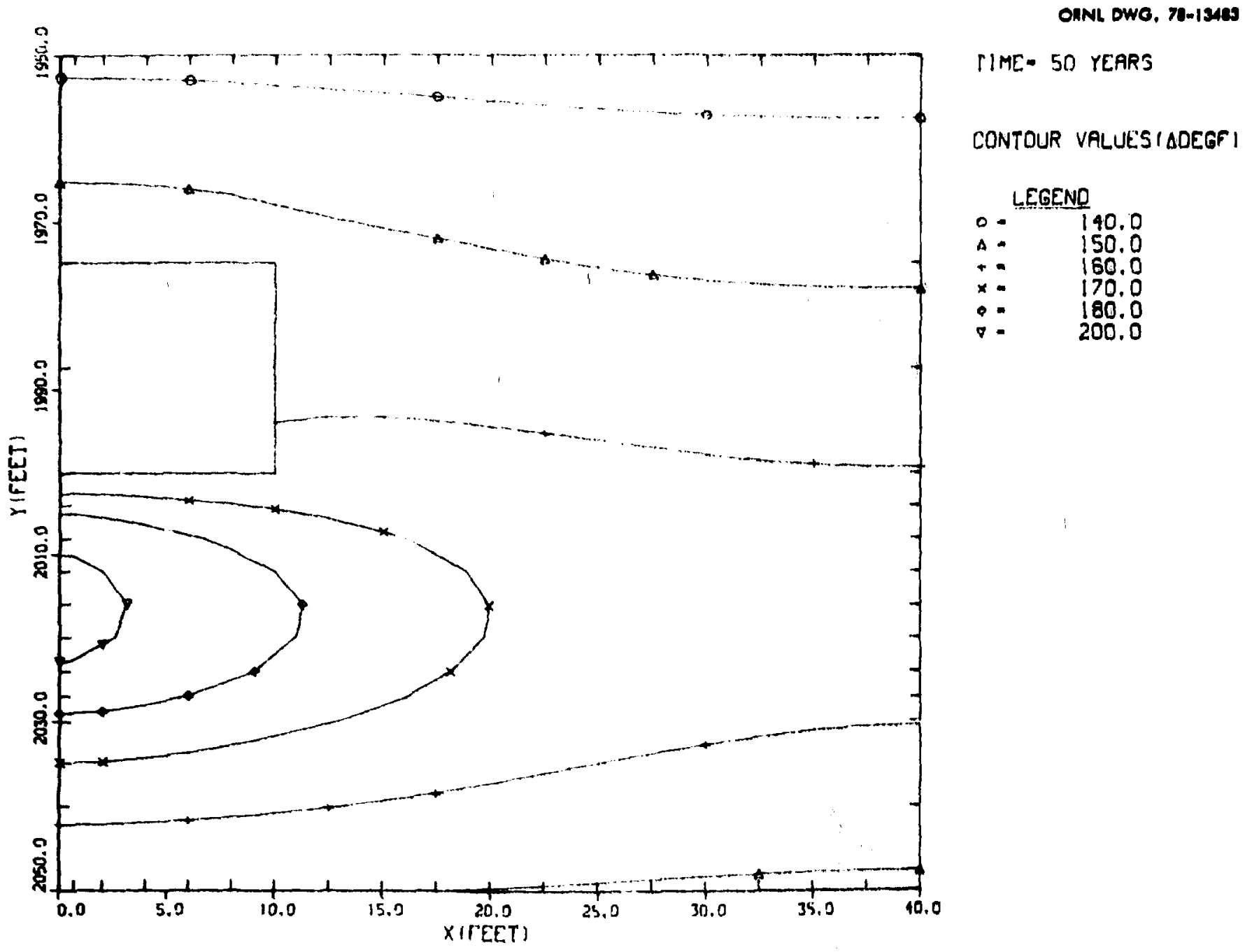

5ig. 33. Isothermal Plot at 50 Years for spent Fuel Buried in Salt at an Areal Loading of $90 \mathrm{~kW}$ per Acre Using a Single-Level Isirial Configuration. 


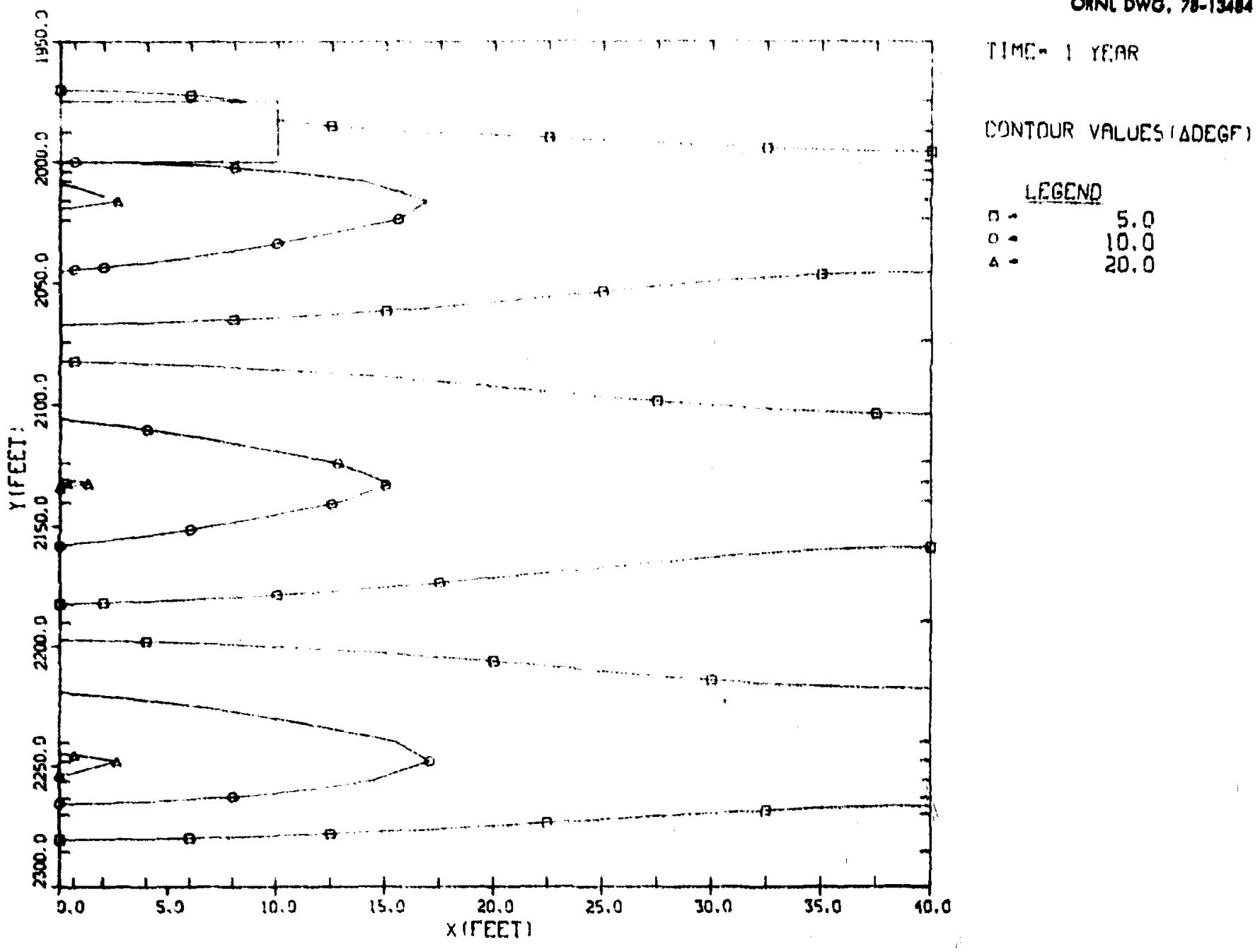

F18. 34. Isothermal. Plot at 1 Year for Spent Fuel Burled In Salt at ar. Areal Loading of $90 \mathrm{~kW}$ per Acre Using a Multl-Level Burlal Configuration. 


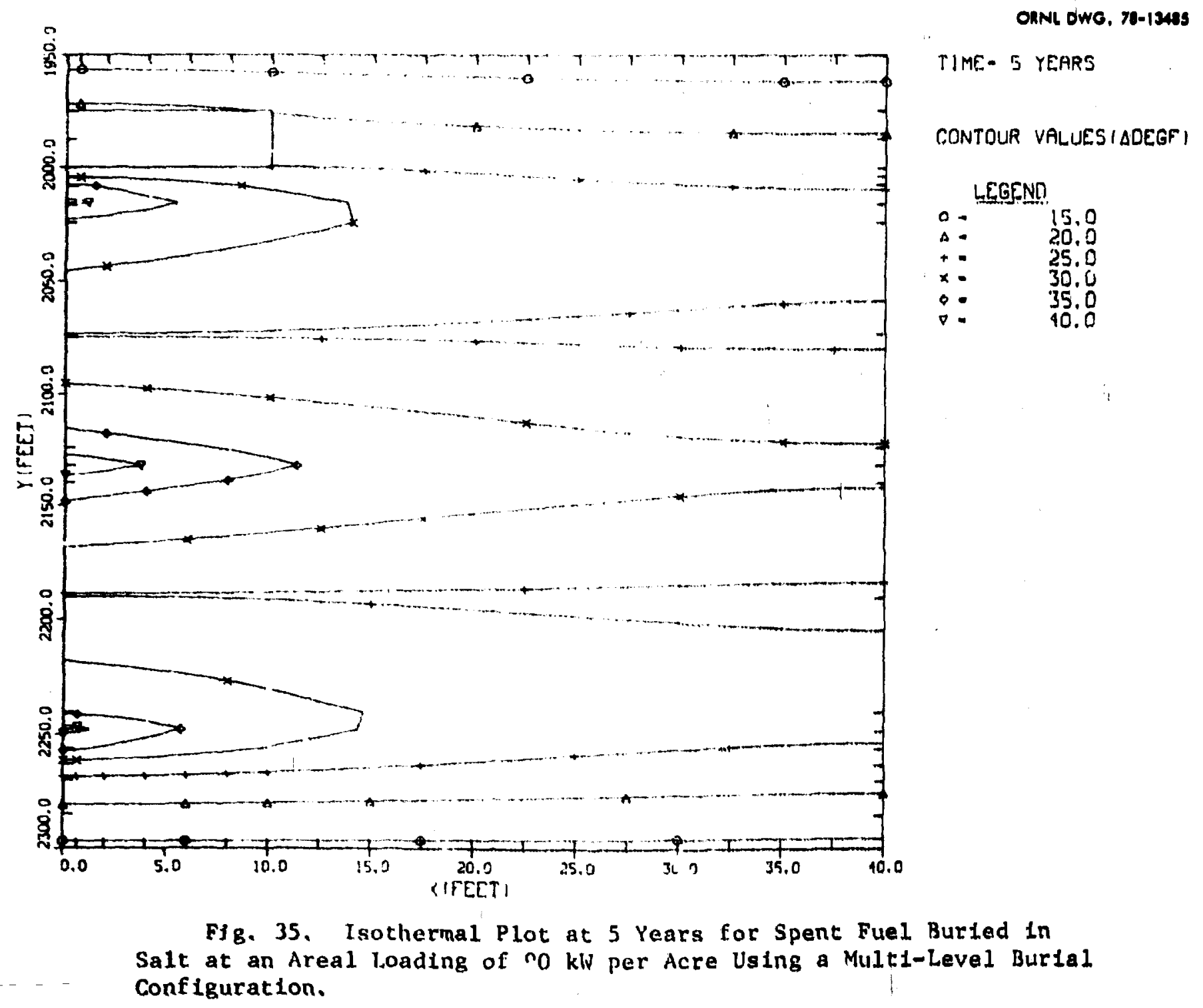




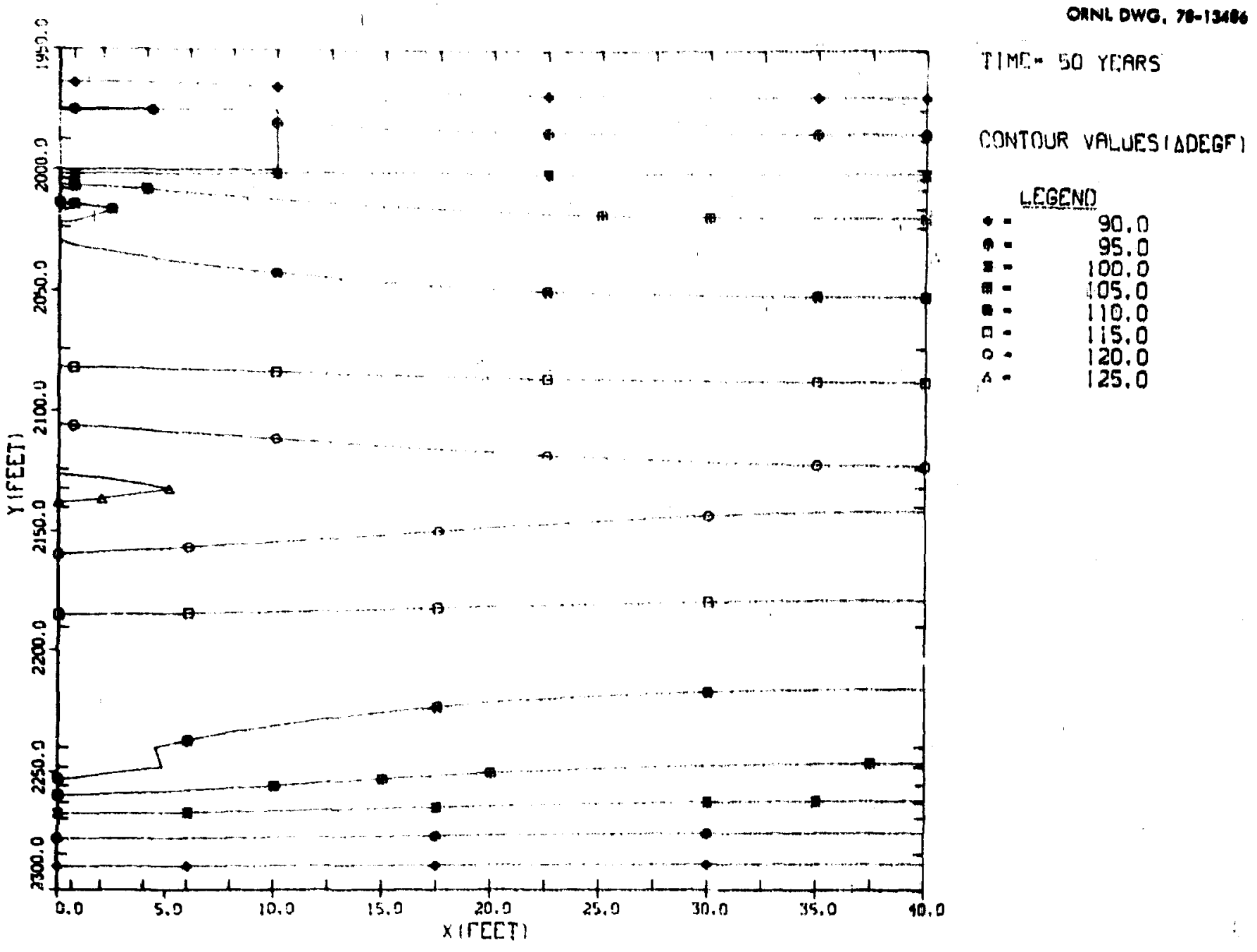

Fig. 36. Isothermal Plot at 50 Years for Spent Fuel Burled in Salt at an Areal Loading of $90 \mathrm{~kW}$ per Acre Using a Multi-Level Burlal Configuration. 
Appendix B

THERMAL CONTOUR PLOTS FOR BURIAL OF WASTE IN GRANITE 


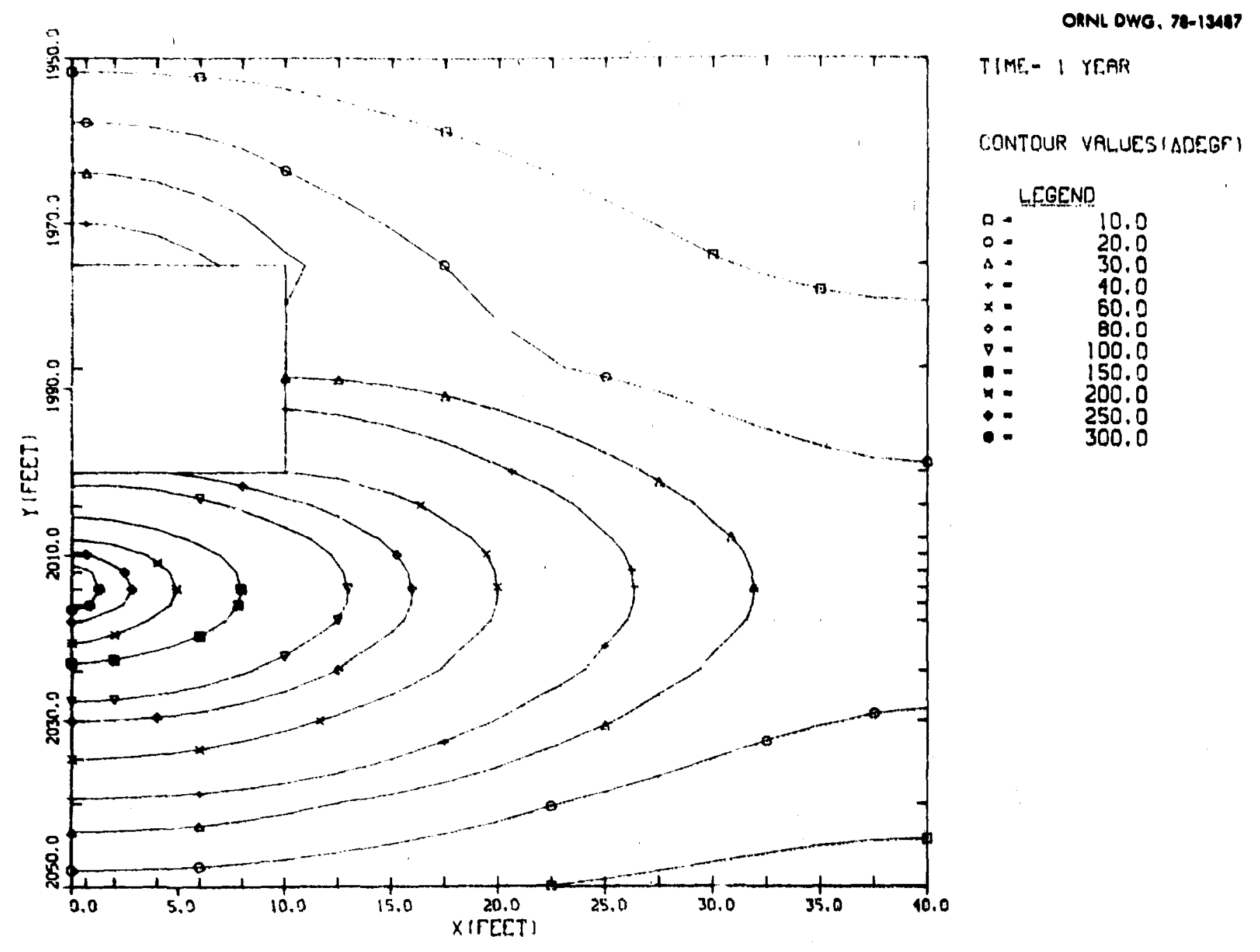

F1g. 37. Isothermal Plot at 1 Year for High-Level Waste Burled in Granite at an Areal Loading of $180 \mathrm{~kW}$ per Acre Using a Single-Level Burial Configuration. 



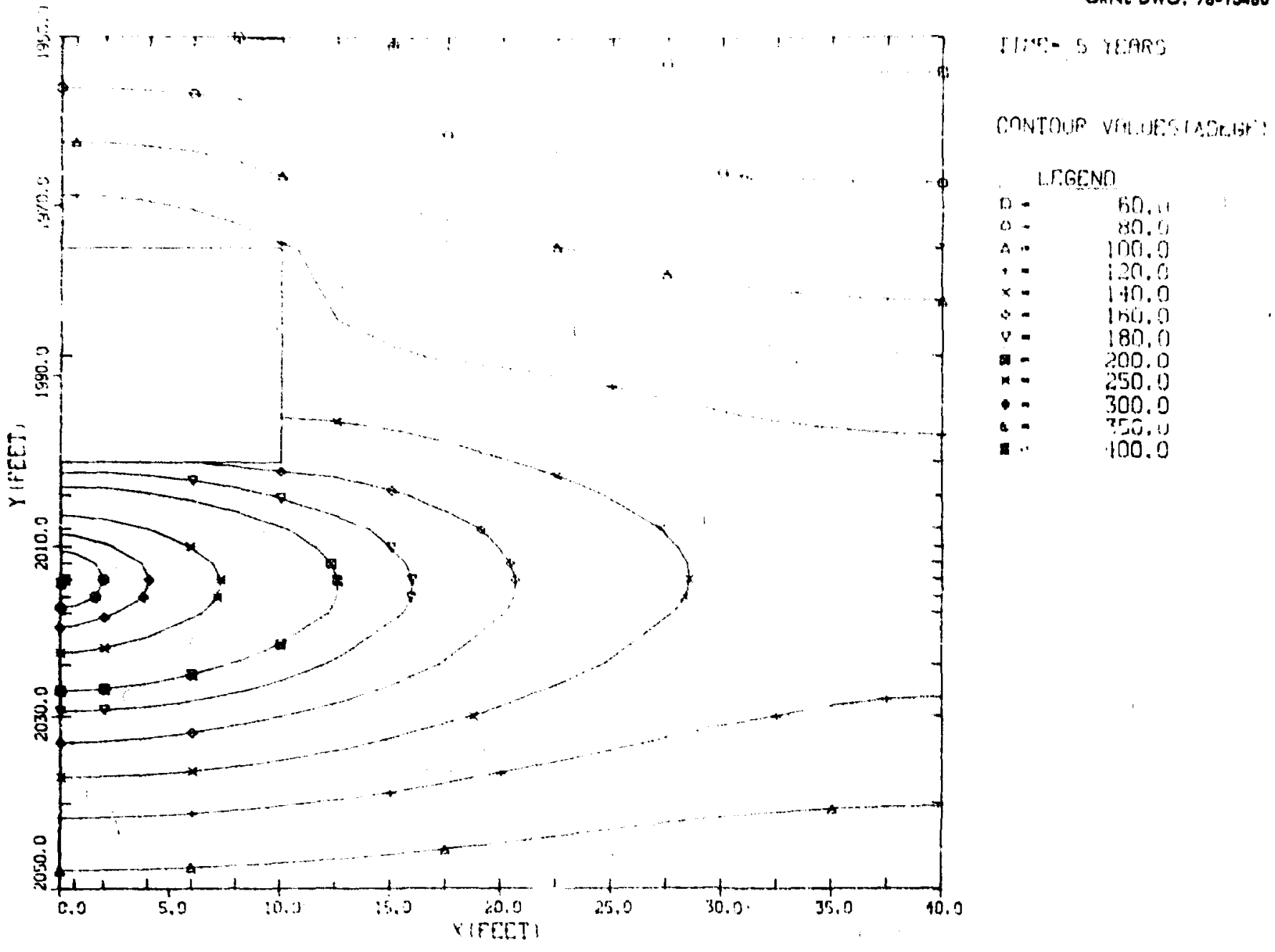

Fig. 38. Isothermal Plot at 5 Years for High-level Waste Burled In Granite at an Areal Loading of $180 \mathrm{k} \cdot \mathrm{W}$ per Acre Using a Single-Level Burial Configuration. 


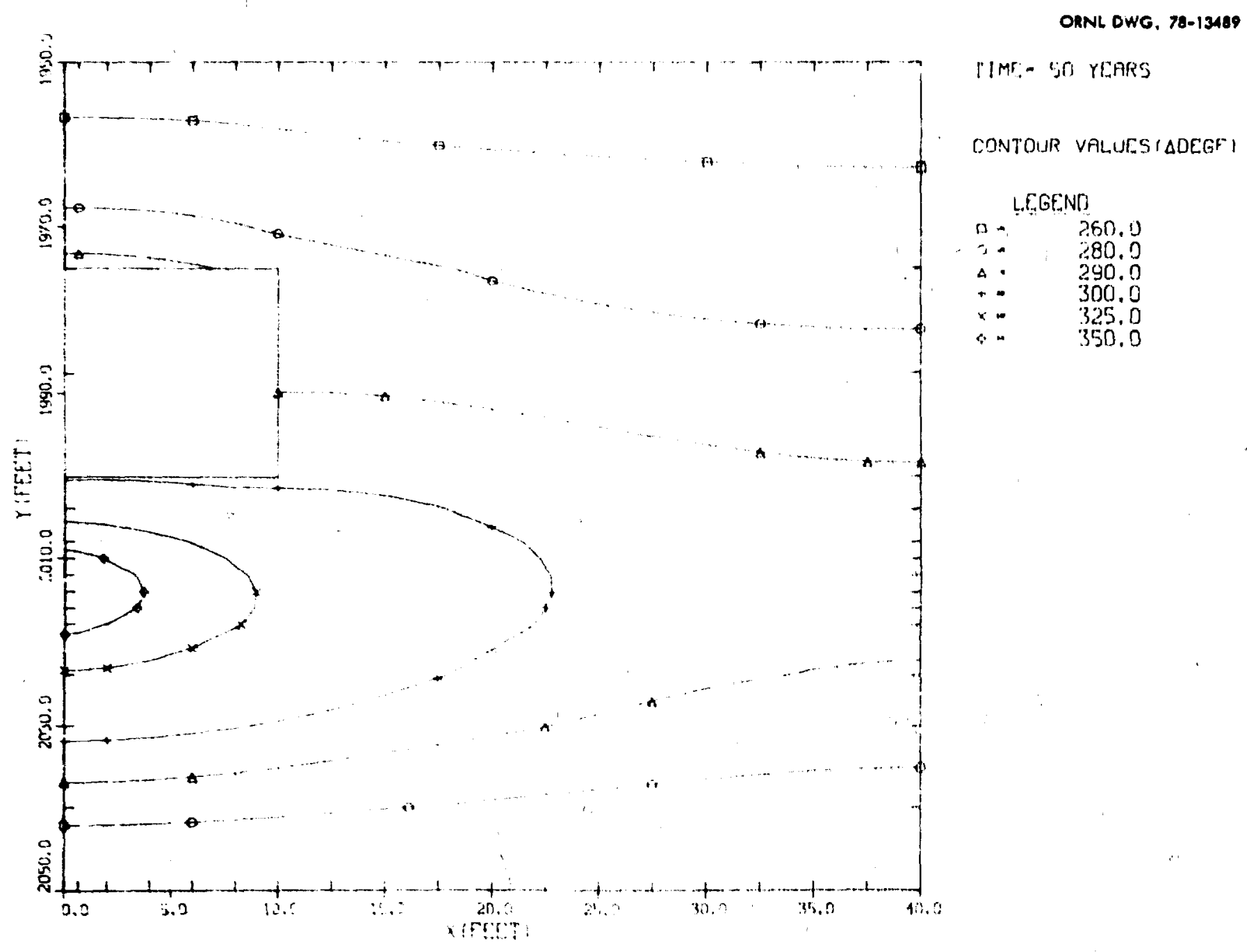

Fig. 39. Isothermal Plot at 50 Vears for Hgh-level Waste Burfed in Granite at on droul Loading of $180 \mathrm{~kW}$ per Acre listng a single-level Burial Configuration. 
ORNL DWG, 78-13490

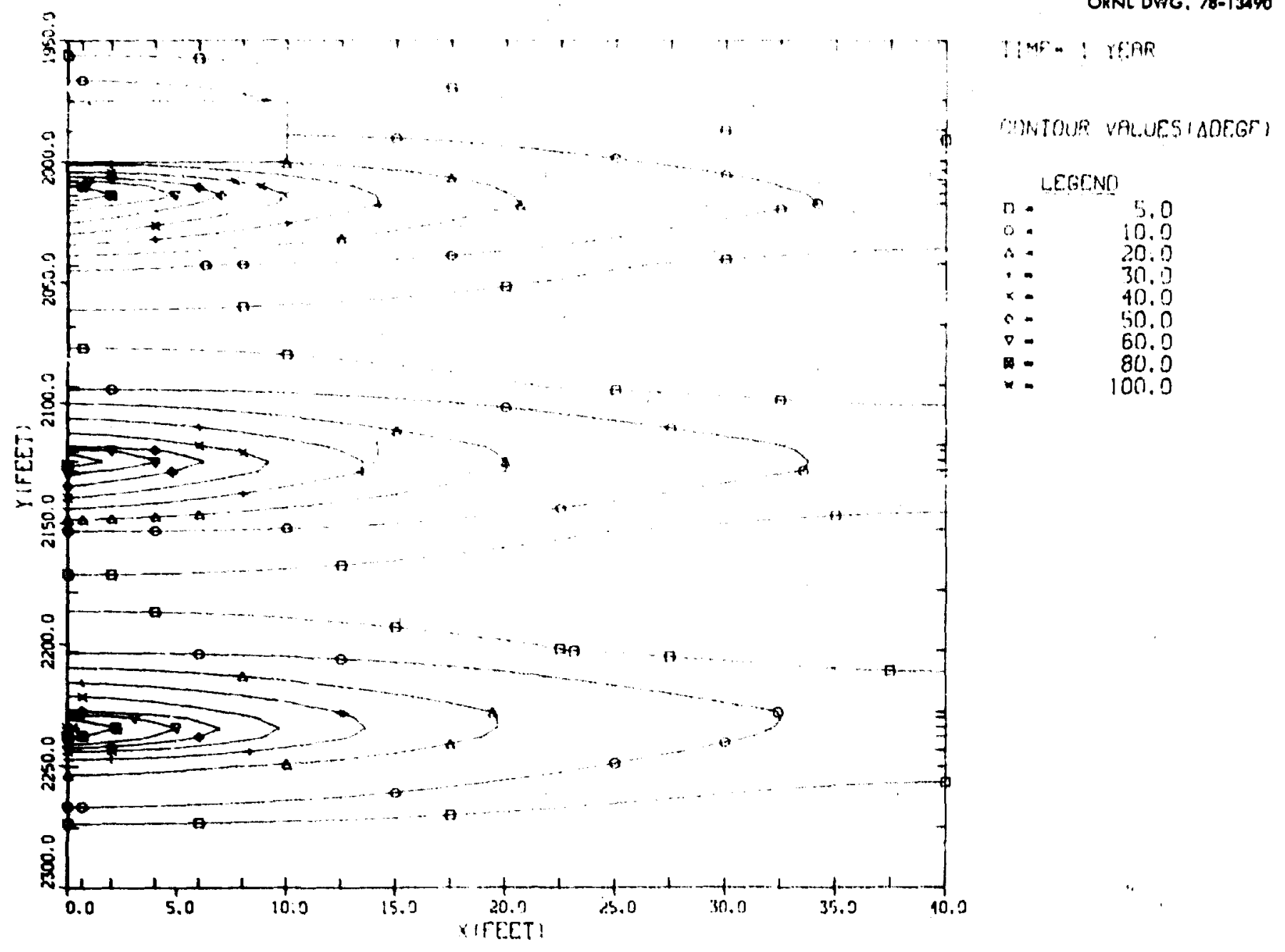

Fig. 40, Isothermal Plot at 1 Year for High-level Waste Burled in Granite at an Areal Loading of $180 \mathrm{~kW}$. per Acre Using a Multt-leve] Burial Configuration. 


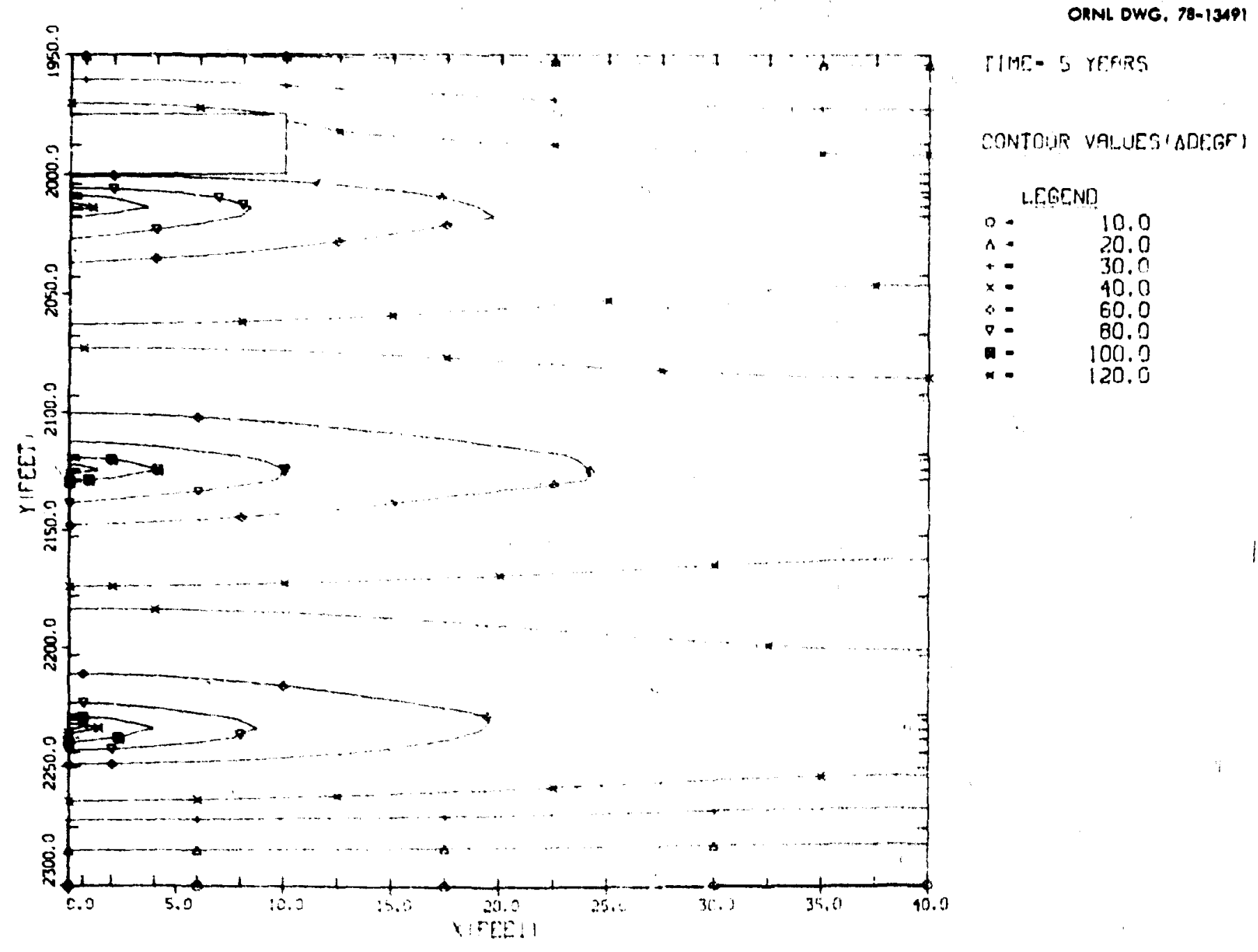

Fig. 41. Isothermal Plot at 5 Years for High-Level Waste Burled in Granite at an Areal loading of $180 \mathrm{~kW}$ per Acre lsing \& Multi-Level Burial Configuration. 
ORNL DWG, 78-13498

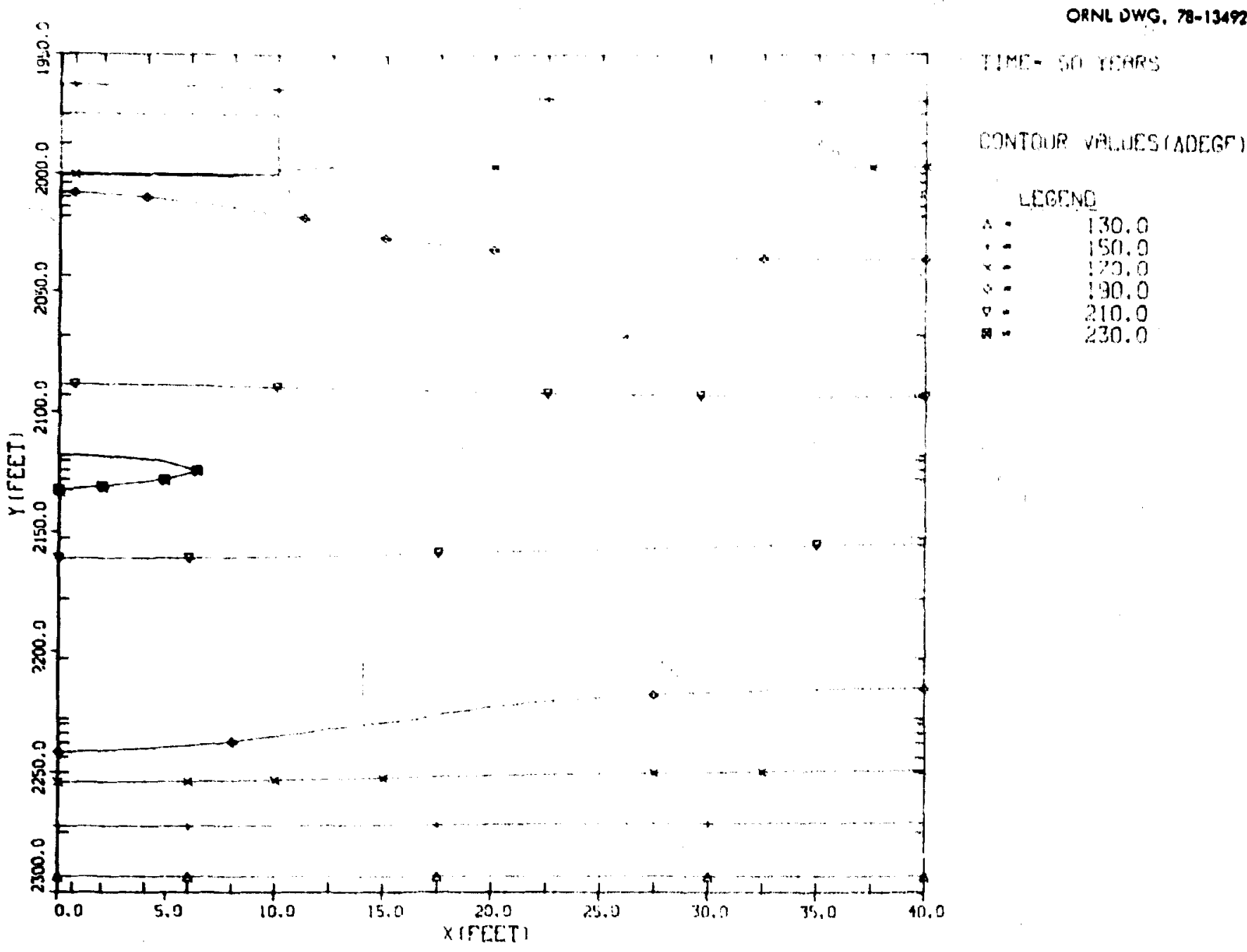

Fig. 42. Isothermal Plot at 50 Years for High-Level Waste Burfed in Cranite at an Areal Loading of $180 \mathrm{~kW}$ per Acre Using a Mult1-Level Burial Configuration. 
ORNL DWC, 78-13493

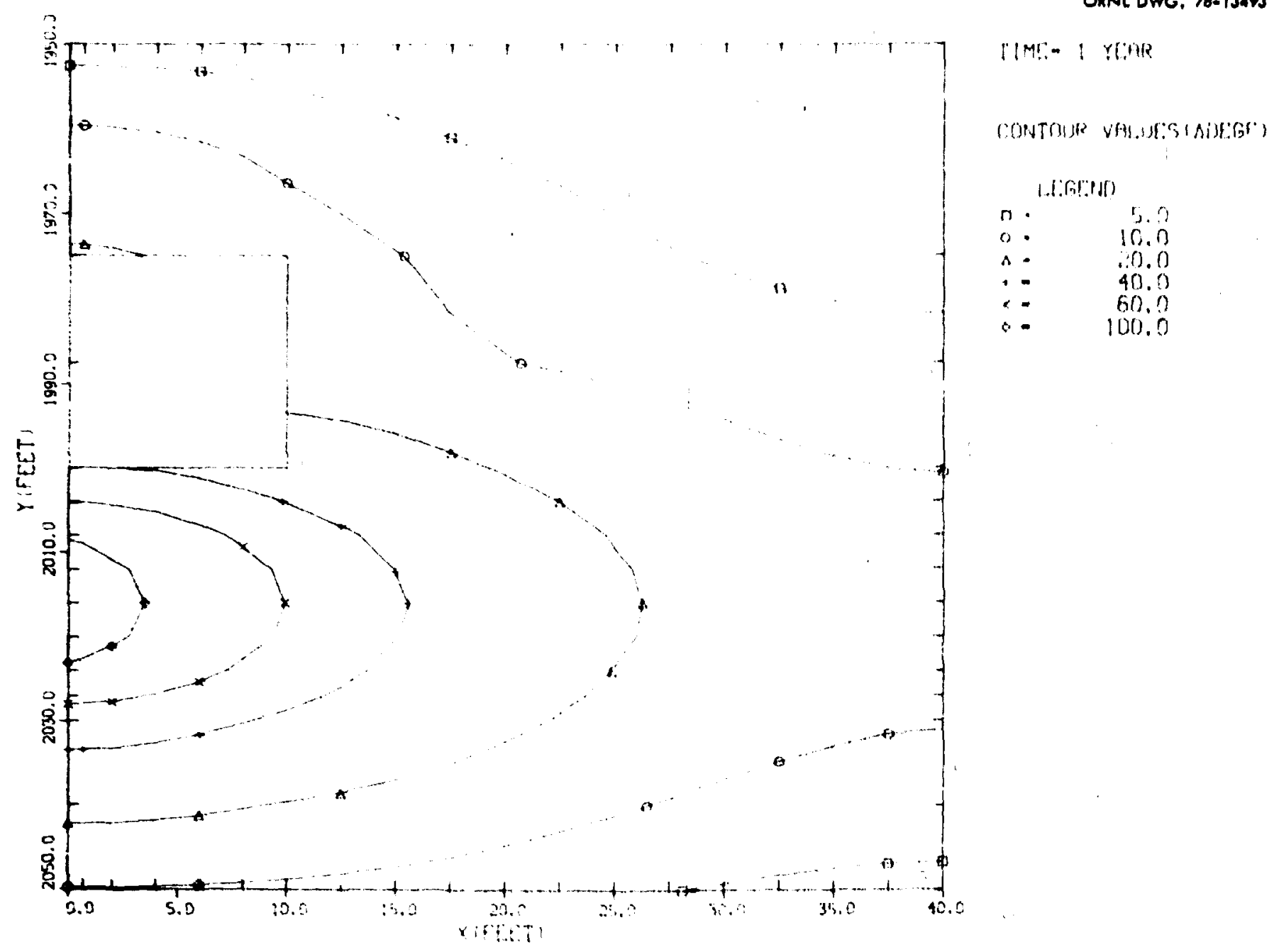

Fig. 43. Isothermal plot at 1 Year for spent Fuel Burled in Granite at an Areal loading of $90 \mathrm{~kW}$ per Acre Using a Single-level Burial configuration. 


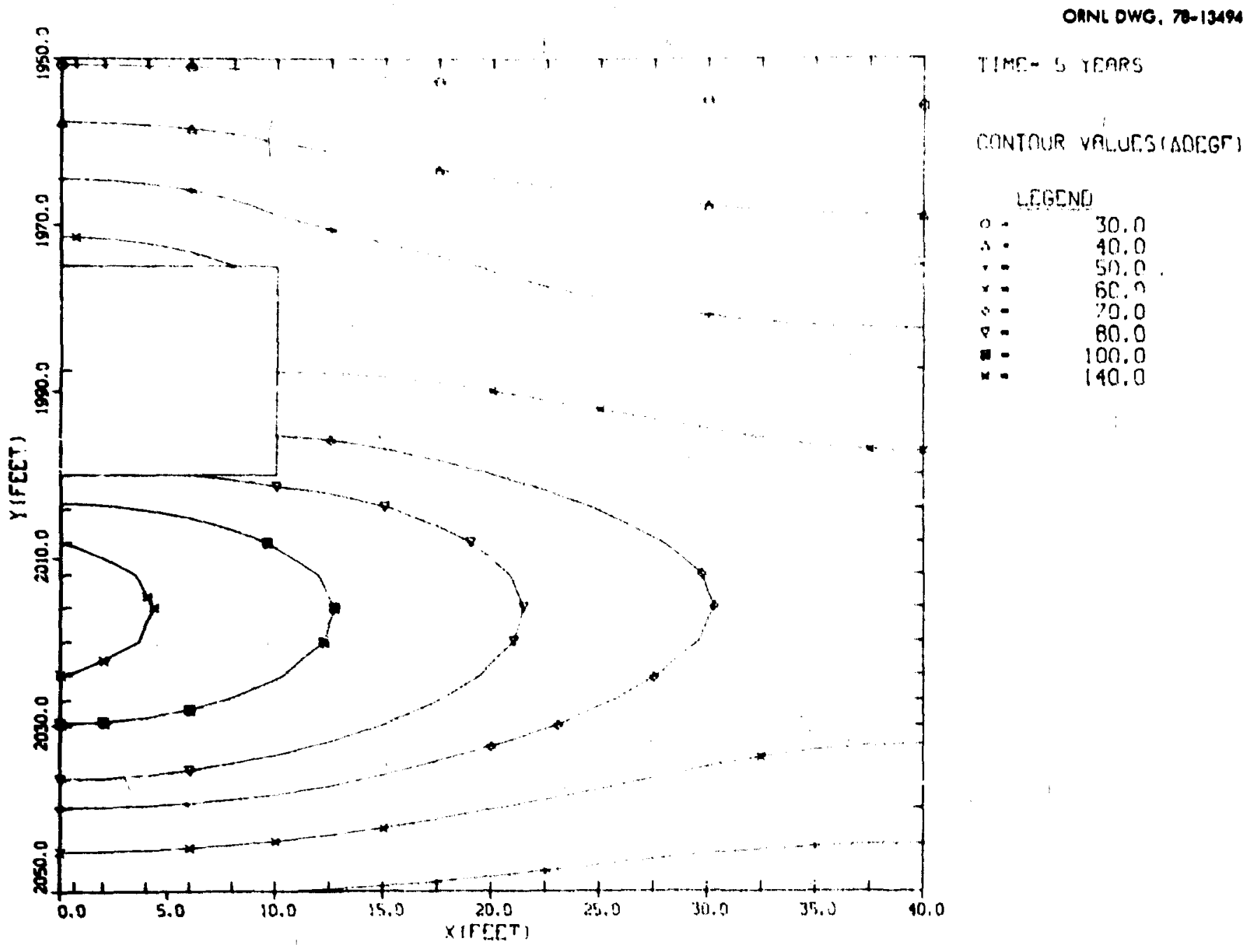

F1g. 44. 1sothermal Plot at 5 Years for Spent Fuel Burled in Granice at an Areal Loading of $90 \mathrm{~kW}$ per Acre Using a Single-level Burial Configuration. 


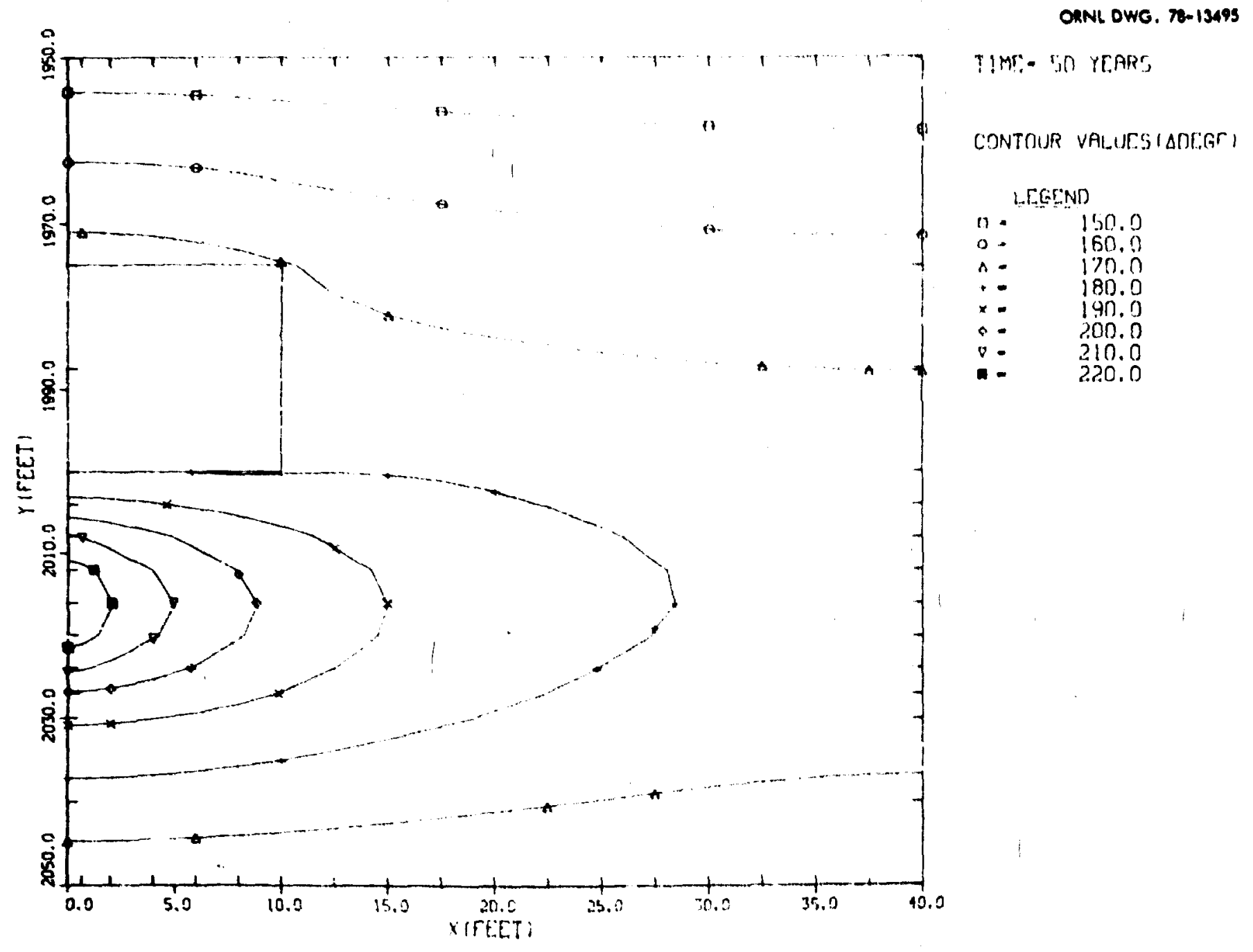

Fig. 45. Isothermal Plot at 50 Years for Spent Fuel Buried in Granite at an Areal Loading of $90 \mathrm{~kW}$ per Acre Using a Single-level Burial Configuration. 


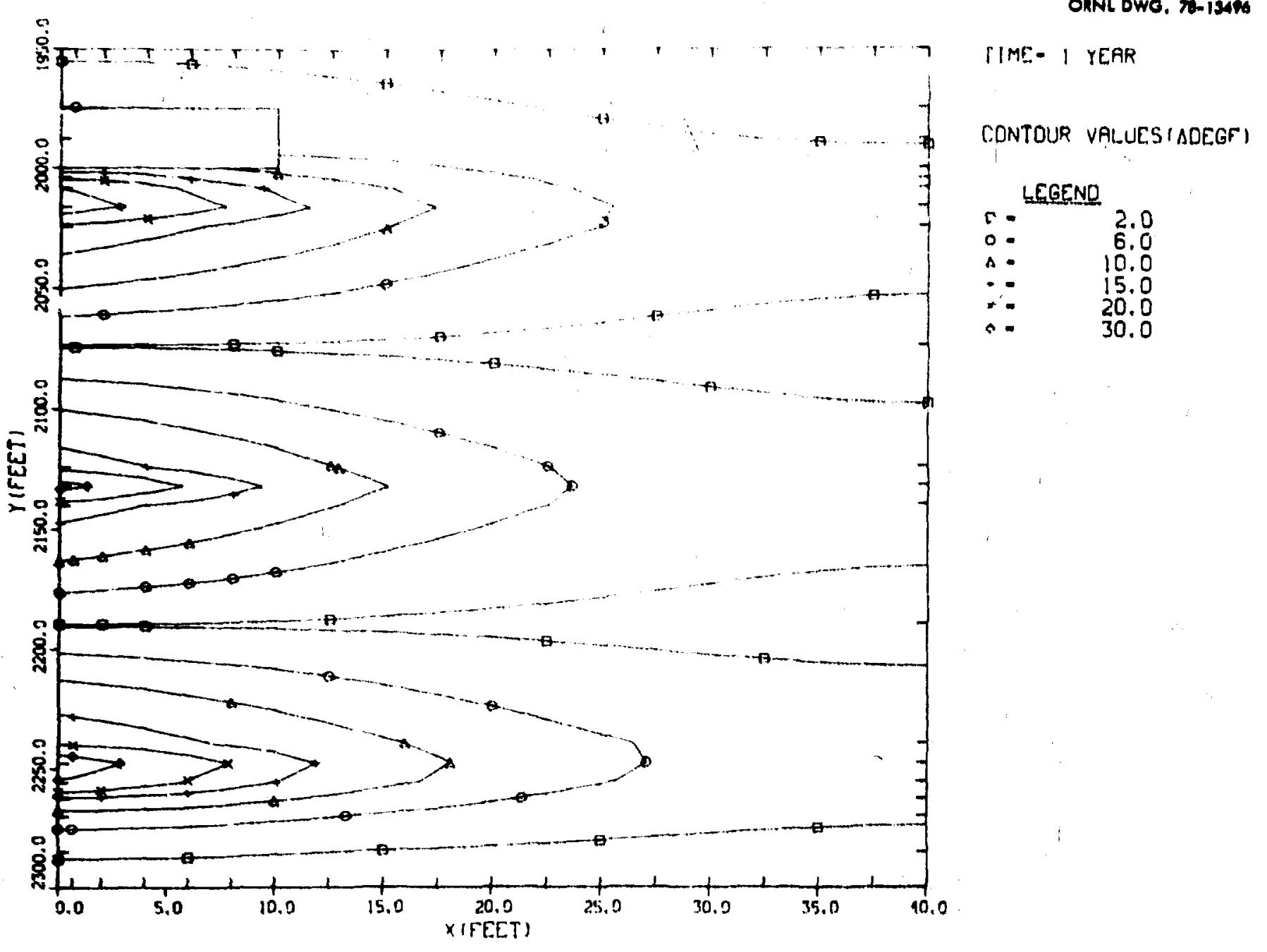

Fig. 46. Isothermal Plot at 1 Year for Spent Fuel Burled in Granite at an Areal Loading of $90 \mathrm{~kW}$ per Acre Using a Multh-level Burial Configuration. 


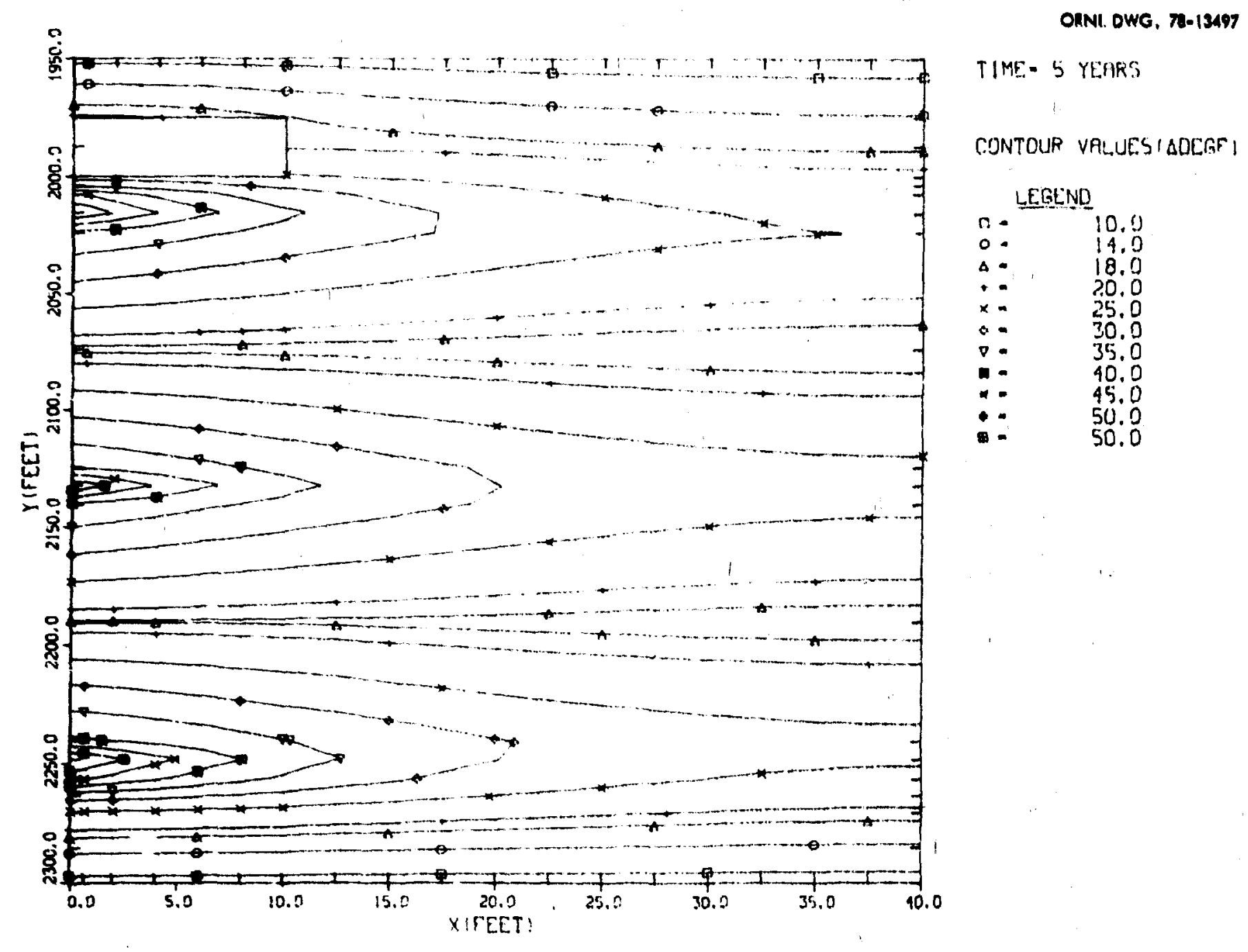

Fig. 47. Isothermal Plot at 5 Years for Spent Fuel Buried in Granite at an Areal Loading of $90 \mathrm{~kW}$ per Acre Using a Multi-Level Burial Configuration. 


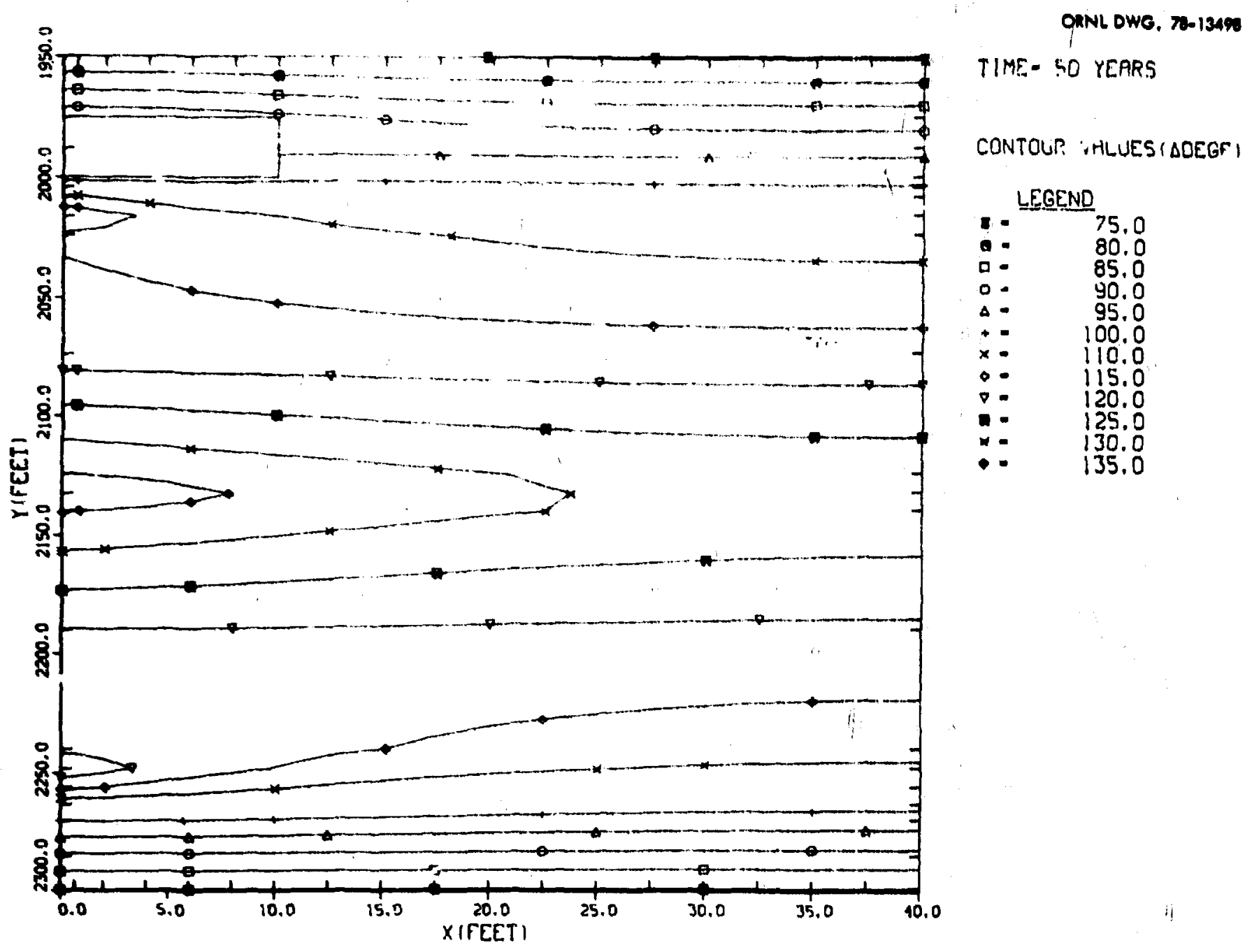

F1g. 48. Isothermal Plot at 50 Years for Spent Fuel Burled in Granite at an Areal Loading of $90 \mathrm{~kW}$ per Acre Jsing a Multi-Level Burial Configuration. 
ORNL/ENG/TM-14

INTERNAL DISTRIBUTION

1. M. Bender

2. R. D. Cheverton

3-7. H. C. Claiborne

8. W. K. Crowley

9. G. E. Giles

1n. R. F. Hibbs

11. L. J. Holloway

12. G. R. Jásny

13. G. H. Jenks

14-18. R. A. Just

19. M. R. Lambert

20. G. H. Llewellyn

21. K. H. Luk

22. J. D. Mason

23. W. C. MeClain
24. H. A. Micchell

25. T. W. Pickel

26. H. Postma

27. M. Siman-Tov

28. E. G. St. Clair

29. H. D. Turner

30. R. S. Hagner

31-32. Central Research Library

33. Document Reference Section

34. Patent Section

35-39. Laboratory Records Department

40. Laboratory Records Department R.C.

41-43. Technical Publications Department

EXTERNAL DISTRIBUTION

44. Director, Research and Technical Support Division, DOE-ORO

45-74. Technical Information Center, P.0. Box 62, Oak Ridge, TN 37830

75-76. W. A. Carbiener, Battelle Memorial Institute, Columbus, $O H$

77. P. F. Gnirk, RE/SPEC Inc., P.0. Box 725, Rapid City, SD 57701

78-79. G. Raines, Barrelle Memorial Institute, Columbus $\mathrm{OH}$

80. F. R. Standerfer, DOE Richland Operations Office, P.0. Box 550, Richland, WA 99352 